$$
\text { UNIVERSIDADE DE BRASÍLIA }
$$

INSTITUTO DE CIÊNCIAS SOCIAIS

CENTRO DE PESQUISA E PÓS-GRADUAÇÃO SOBRE AS AMÉRICAS PROGRAMA DE PÓS-GRADUAÇÃO EM ESTUDOS COMPARADOS SOBRE AS AMÉRICAS

\title{
REDD+ Indígena Amazônico e as dinâmicas de atuação política de uma organização indígena
}

\author{
Isabel Rodrigues de Mesquita
}


UNIVERSIDADE DE BRASÍLIA

INSTITUTO DE CIÊNCIAS SOCIAIS

CENTRO DE PESQUISA E PÓS-GRADUAÇÃO SOBRE AS AMÉRICAS

PROGRAMA DE PÓS-GRADUAÇÃO EM ESTUDOS COMPARADOS SOBRE AS

AMÉRICAS

\section{REDD+ Indígena Amazônico e as dinâmicas de atuação política de uma organização indígena}

Isabel Rodrigues de Mesquita

Trabalho apresentado ao Programa de Pós-Graduação em Ciências Sociais - Estudos Comparados sobre as Américas do Centro de Pesquisa e Pós-Graduação sobre as Américas (CEPPAC) da Universidade de Brasília, para a obtenção do Título de Mestre em Estudos Comparados sobre as Américas, ob orientação do Prof. Dr. Cristhian Teófilo da Silva.

Banca examinadora:

Prof. Dr. Cristhian Teófilo da Silva (presidente - CEPPAC/UnB)

Prof. Dr. Stephen Graint Baines (membro interno - DAN/CEPPAC/UnB)

Dr. Henyo Trindade Barretto Filho (membro externo - IIEB)

Profa. Dra. Doris Aleida Villamizar Sayago (suplente - CDS/UnB)

Brasília

Junho de 2016 
Para todas as famílias e pessoas separadas de suas terras de origem.

India is not just a place.

India is not just a people.

India is the celestial music,

And inside that music

Anybody from any corner of the globe

Can find the real significance of life.

(Sri Chinmoy) 


\section{Agradecimentos}

Dedico esse humilde trabalho a todos que se empenham diariamente na construção de um mundo que abrigue modos de ser e pensar diversos. Trabalhar, estudar e viver em contato com as lutas indígenas é inspirador e ao mesmo tempo sofrido; espero que o esforço desses últimos dois anos (parcialmente aqui apresentado) contribua para abrir frestas de percepção sobre algumas questões que tocam essa luta.

Em ordem cronológica, acompanhando o desenvolvimento da pesquisa:

Agradeço à Renata, pela amizade de dez anos, por ter me abrigado em Brasília, por ter me apresentado o CEPPAC (e ter insistido para que eu cursasse uma disciplina como aluna especial sobre etnodesenvolvimento, ministrada pelo Prof. Ricardo Verdum - a quem também sou grata pelos ensinamentos), pelo apoio e pelas trocas desde o período de seleção do projeto até a sua finalização.

Agradeço à Bianca pela sua simples existência. Sou imensamente grata pela companhia incansável em todos os momentos, inclusive nos estudos, e pelo apoio em tantas maneiras ao longo desses últimos dois anos que tornaram possível não só esse mestrado como a vida em Brasília!

Dificilmente encontraria palavras para expressar minha gratidão ao meu orientador, Prof. Cristhian, com quem aprendi muito a cada encontro. Foi uma imensa satisfação ter feito essa jornada sob sua orientação, que me instigou constantemente, inclusive quando eu me sentia desmotivada. Além disso, alguém que é uma inspiração para qualquer um que almeje ser professor, pois suas aulas sempre abrem novos horizontes para o pensamento, mesmo a partir de debates ou textos já conhecidos.

Agradeço à CAPES e ao CEPPAC pela oportunidade de realizar essa pesquisa, e a todos os professores e funcionários pelos aprendizados e convivência.

Agradeço aos profs. Stephen G. Baines e Henyo T. Barretto Filho, pelas avaliações e sugestões que certamente estimularam a continuidade e aprofundamento deste trabalho.

Agradeço ao Gipsy Kings, trilha sonora que embalou inúmeras tardes e noites de leitura e escrita. 
Agradeço ao IPAM pela possibilidade de vir à Brasília e ter realizado esse mestrado; agradeço especialmente a Paulo Moutinho, Mariana Christovam, Fernanda Bortolotto e Martha Fellows, com quem aprendi e troquei muito cotidianamente a respeito desse universo tão complexo relacionado a mudanças climáticas, e que me apoiaram de diversas maneiras para a realização desta pesquisa. Agradeço a Chris Van Dam e a Deborah Delgado por me abrirem muitas portas nesse campo de trabalho e estudo.

Agradeço aos amigos Tamilis, Thais, Fernão, Mônica, Etel, Priscila (mesmo à distância), Hima, Silvia, Felipes (os dois), Nathalia, Mara, Luma e Dani pela presença ao longo dessa jornada (eu possivelmente teria enlouquecido sem vocês por perto).

Por fim, não poderia deixar de agradecer às pessoas que contribuíram indiretamente para a realização desta pesquisa simplesmente por serem responsáveis por eu ser, em tantos sentidos, a pessoa que sou hoje - à família de sangue, Antonio, Zoraide, Renata e João Pedro, sou muito grata por tudo, hoje e sempre. À família que não é sanguínea, mas que carrego sempre, à família "Te Pego no Cantinho": obrigada! 
Lista de figuras e tabelas

Figura 1. Sujeitos que influenciam as negociações sobre o clima

Figura 2. Avanços das experiências-piloto de RIA por país. 
Lista de siglas

ADP - Ad-hoc working group on the Durban Platform for Enhanced Action

AFN - Assembly of First Nations

AIDESEP - Asociación Interétnica de Desarrollo de la Selva Peruana

AIPP - Asia Indigenous Peoples Pact

APA - Amerindian Peoples Association of Guyana

CDB - Convenção de Diversidade Biológica

CIDOB - Central de Pueblos y Comunidades Indígenas del Oriente Boliviano

CISA - Consejo Indio de Sudamerica

CLACSO - Consejo Latinoamericano de Ciencias Sociales

CMP - Meeting of the Parties

COIAB - Coordenação das Organizações Indígenas da Amazônia Brasileira

COICA - Coordinadora de las Organizaciones Indígenas de la Cuenca Amazónica

CONFENIAE - Confederación de Nacionalidades Indígenas de la Amazonia

Ecuatoriana

CONIVE - Consejo Nacional Indio de Venezuela

CONAP - Confederación de Nacionalidades Amazónicas del Perú

COP - Conferências das Partes

ECO 92 - Conferência das Nações Unidas sobre o Meio Ambiente e Desenvolvimento

FIP - Forest Investment Program

FOAG - Fédération des Organisations Autochtones de Guyane

FUNAI - Fundação Nacional do Índio

GIZ - Agência de Cooperação Técnica Alemã

ICC - Inuit Circumpolar Council

IIPFCC - International Indigenous Peoples' Forum on Climate Change

IPAM - Instituto de Pesquisa Ambiental da Amazônia

IPCC - Intergovernmental Panel on Climate Change 
IWGIA - International Work Group for Indigenous Affairs

MDL - Mecanismo de Desenvolvimento Limpo

OIS - Organisatie van Inheemsen in Suriname

OIT - Organização Internacional do Trabalho

ONG - Organização Não-Governamental

ONIC - Organización Nacional Indígena de Colombia

ONU - Organização das Nações Unidas

OPIAC - Organización de Pueblos Indígenas de la Amazonia Colombiana

REDD - Redução Compensada de Emissões por Desmatamento e Degradação Florestal

REDD+ - Redução Compensada de Emissões por Desmatamento e Degradação

Florestal e ações de conservação, manejo sustentável das florestas e de aumento dos estoques de carbono florestal

RIA - REDD+ Indígena Amazônico

SBI - Subsidiary Body for Implementation

SBSTA - Subsidiary Body for Scientific and Technical Analysis

Tebtebba - Indigenous Peoples' International Centre for Policy Research and Education

TIPNIS - Territorio Indígena y Parque Nacional Isiboro-Secure

UNFCCC - United Nations Framework Convention on Climate Change

UNI - União das Nações Indígenas

WCIP - World Council of Indigenous Peoples

WWF - World Wildlife Fund 


\section{Resumo}

Esta pesquisa busca compreender a inserção de uma organização indígena transnacional amazônica, a COICA, nas negociações internacionais sobre o clima, a partir da construção de sua proposta de REDD+ Indígena Amazônico. Tal proposta é parte de uma dinâmica de atuação política mais abrangente da COICA, com vistas a fortalecer reivindicações indígenas em espaços políticos interétnicos. As negociações internacionais sobre o clima são apresentadas como um campo em disputa entre diversos atores, do qual participam organizações indígenas de várias partes do mundo. Para ser reconhecida nestes espaços, a utiliza a mesma linguagem empregada por seus interlocutores não-indígenas, de maneira a tornar suas pautas inteligíveis e ouvidas. O uso dessa linguagem é entendido aqui como estratégia eficaz encontrada pela COICA e por outras organizações indígenas para fazer-se reconhecer enquanto sujeitos políticos legítimos no campo das negociações sobre o clima.

Palavras-Chave: mudanças climáticas, organizações indígenas, REDD+, diálogo interétnico. 


\begin{abstract}
This research aims to comprehend how a transnational indigenous organization from the Amazon basin, COICA, acts in the international climate change negotiations sphere through the analysis of its proposal of "Amazonian Indigenous REDD+". In order to do so, the climate change negotiations are here presented as a political arena, in dispute by diverse stakeholders, and in which indigenous organizations from all over the world participate. COICA'S Indigenous REDD+ proposal is understood as part of a broader dynamic of political action taken by COICA in other fields, in order to present indigenous claims in diverse interethnic political spaces. To acknowledge legitimacy in such spaces, COICA uses the same language as the non-indigenous subjects present in these spaces, as a way to make its claims intelligible. The use of such a language is here comprehended as an effective strategy found by COICA and other indigenous organizations to make themselves recognized as legitimate political subjects in the climate change negotiations arena.
\end{abstract}

Key Words: climate change, indigenous organizations, REDD+, interethnic dialogue 


\section{Sumário}

Apresentação .................................................................................................. 3

Capítulo 1: Mudanças climáticas: um campo em disputa ................................................ 14

1.1 Por que estudar mudanças climáticas nas Ciências Sociais? .................................. 15

1.2 Polarizações no campo das mudanças climáticas ................................................... 19

1.2.1 Países do Anexo I versus Países não-Anexo I …………………………………..... 21

1.2.2 Reivindicações por justiça climática............................................................... 24

1.3 Mecanismos institucionalizados nas negociações internacionais: mais elementos

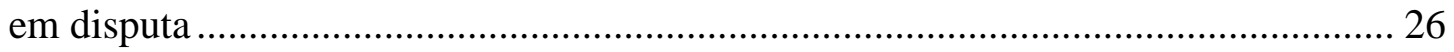

1.4 Visões sobre mudanças climáticas: geopolítica do conhecimento ......................... 28

1.5 Expectativas e imaginários construídos sobre os povos indígenas........................ 32

1.6 Participação de povos indígenas no debate sobre mudanças climáticas ............... 36

1.6.1 As Conferências das Partes: espaços que possibilitam a participação indígena?

1.6.2 Participação de organizações indígenas nas negociações internacionais do clima (COP) 38

Capítulo 2: A COICA e sua trajetória de atuação política internacional.......................... 41

2.1 Movimento indígena em escala mundial .............................................................. 41

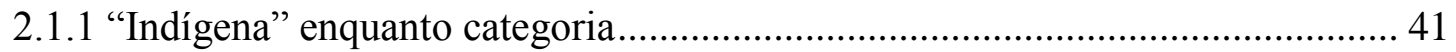

2.1.2 Movimento indígena: no singular ou no plural? ................................................ 43

2.1.3 Articulação transnacional do movimento indígena ........................................... 45

2.2 A COICA: constituição, consolidação e atuação indígena ambientalista.............. 48

2.2.1 A formação de organizações indígenas amazônicas ............................................ 48

2.2.2 A participação dos povos indígenas amazônicos em fóruns internacionais ...... 50

2.2.3 A formação de organizações indígenas amazônicas transnacionais: o CISA e a

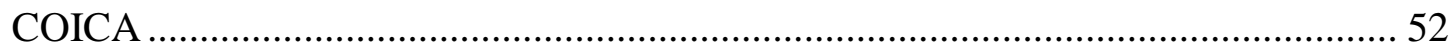

2.2.4 Os primeiros anos da COICA e a conformação de sua estrutura e modus

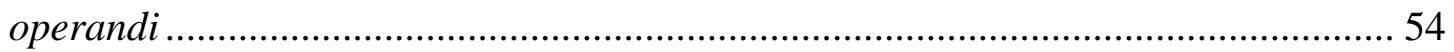

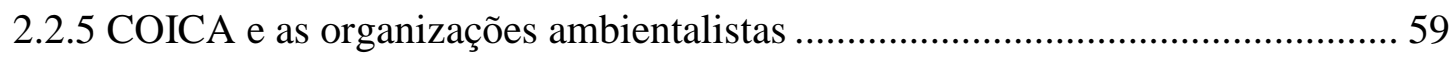

2.2.6 Atuação da COICA na agenda ambientalista: a Convenção da Diversidade

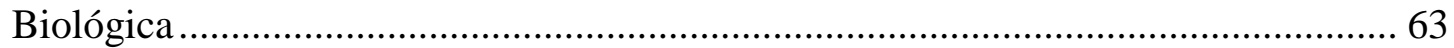

Capítulo 3: Apropriação, resistência e comunicação: RIA como instrumento político de diálogo 


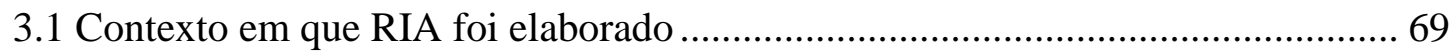

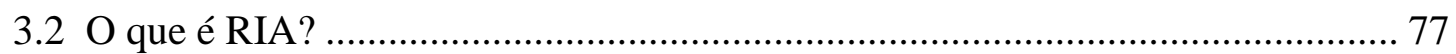

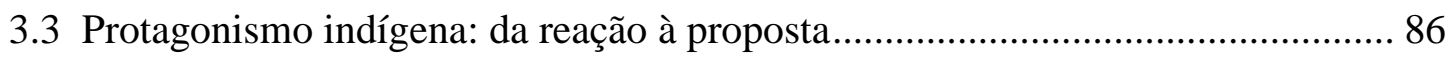

3.4 "Falar a língua do outro", fazer-se ouvir: tradução e mediação ........................... 87

3.4.1 A configuração de um discurso político indígena: escolhas e críticas .............. 87

3.4.2 Como um sujeito indígena pode fazer política na esfera nacional/internacional? 92

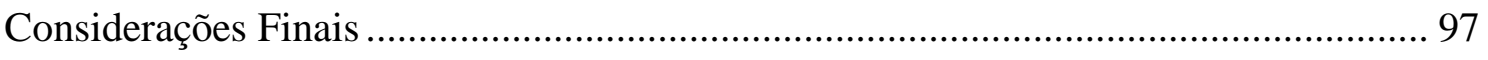

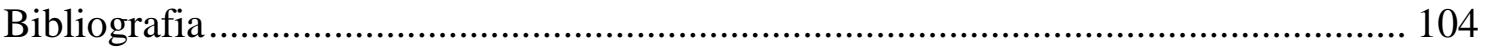

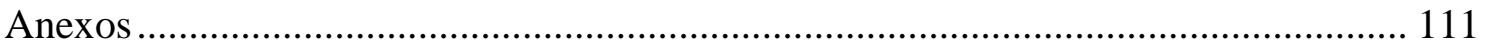


Apresentação

Para começar, apresento este trabalho com um relato da trajetória que resultou neste e que deixa claro meu lugar de fala, aspectos que caracterizarão o que é aqui exposto. Em 2012 fui contratada como assistente de pesquisa de uma Organização NãoGovernamental (ONG), o Instituto de Pesquisa Ambiental da Amazônia (IPAM) para trabalhar com o tema de mudanças climáticas junto a organizações indígenas principalmente brasileiras, mas também da bacia amazônica, tendo um trabalho próximo à Coordenação das Organizações Indígenas da Amazônia Brasileira (COIAB) e à Coordinadora de las Organizaciones Indígenas de la Cuenca Amazónica (COICA). Foi nesse momento que me envolvi com a discussão sobre o mecanismo de REDD+ e conheci a proposta de REDD+ Indígena Amazônico (RIA) elaborada pela COICA.

Destaco aqui o importante papel que o trabalho no IPAM teve para a pesquisa, não apenas por ter sido a porta de entrada para este universo de mudanças climáticas, REDD+ e RIA (até então para mim desconhecido), como também por ter possibilitado a interlocução com organizações e pessoas que são parte de uma rede de organizações que acompanha as discussões sobre mudanças climáticas, o que certamente proporcionou uma visão bastante próxima e privilegiada de como essas organizações atuam inclusive o IPAM, como parte desta rede. Foi também graças a este trabalho que estabeleci contato direto com coordenadores e técnicos da COICA, e inclusive participei de oficinas e reuniões promovidas pela organização que auxiliam a percepção sobre RIA aqui apresentada. Posso assumir, portanto, que ocupo um lugar de fala específico como pesquisadora inserida neste universo a partir do lugar ocupado enquanto parte das organizações ambientalistas do Sul (lugar que contém uma especificidade, conforme será apresentado no Capítulo 1).

Em 2012, eu particularmente tinha muitas ressalvas em relação ao mecanismo de REDD+, especialmente pelas diversas críticas feitas por movimentos sociais e outras organizações da sociedade civil (voltarei a isso no Capítulo 1); por isso, me chamou bastante atenção que a COICA fizesse uma proposta de RIA. Até o final de 2013, segui sem maiores respostas a esse estranhamento em relação à RIA, e foi esse estranhamento que me levou à pesquisa, que surgiu como desdobramento de uma pergunta aparentemente simples: "o que é RIA"? A essa pergunta se seguiram tantas outras que foram guiando a pesquisa, muitas vezes por caminhos que foram abandonados, até 
encontrar o percurso que resultou no presente trabalho: "qual é o significado de RIA para o(s) movimento(s) indígena(s) e para movimentos sociais de maneira mais abrangente?"; "como a COICA apresenta RIA e se insere nos debates e negociações internacionais sobre o clima?”; “como RIA ganha fôlego enquanto proposta após tantas críticas ao mecanismo de REDD+"; e por fim, a pergunta que se desdobrou em inúmeras outras: "como RIA pode ser entendido sob uma perspectiva analítica antropológica?". A partir dessa última pergunta, nos últimos dois anos me coloquei tantas outras perguntas: seria a proposta de RIA uma resposta contra-hegemônica ao mecanismo hegemônico de REDD+? Nesse sentido, seria RIA uma apropriação cultural ou política subversiva de um conceito (REDD+), ou uma captura discursiva utilizada como estratégia política? Seria RIA parte de um processo de etnogênese ${ }^{1}$ que ganha novas proporções em um mundo globalizado, entendida como uma forma de resistência indígena?

A pesquisa foi desenhada de maneira abordar essas questões, e considerando, de um lado, a especificidade da COICA enquanto sujeito político indígena e transnacional e, de outro, a especificidade do campo político em que a proposta de RIA é apresentada, primordialmente nas Conferências das Partes (COP) da Organização das Nações Unidas (ONU). No projeto de pesquisa, foram apresentados os seguintes objetivos e metodologias:

- Mapeamento, a partir de fontes secundárias, de organizações indígenas transnacionais que participam, como a COICA, das negociações sobre o clima;

- Mapeamento, a partir de fontes secundárias, de iniciativas da COICA no âmbito internacional;

- Descrição do campo das negociações de mudanças climáticas (sujeitos envolvidos e principais aspectos de debate), no qual as relações interpessoais e interorganizacionais resultaram na elaboração da proposta de RIA (a partir da minha própria inserção neste campo e de revisão bibliográfica);

- Descrição da trajetória (formação e consolidação) da COICA como organização indígena transnacional, com ênfase nos seus posicionamentos em temas

\footnotetext{
${ }^{1}$ Há debates na Antropologia acerca do conceito de "etnogênese", sendo algumas referências para a definição deste conceito apresentadas por Hill (1996) e Barretto Filho (1992). Para os fins deste trabalho, a noção de etnogênese remete ao processo de originação de novos termos para uma ação política interétnica.
} 
relacionados a meio ambiente e mudanças climáticas (entrevistas e fontes secundárias - documentos da COICA e textos que descrevem sua atuação).

O planejamento da pesquisa era acompanhar a COICA em três momentos distintos: a COP20, realizada em dezembro de 2014 no Peru e duas reuniões de planejamento para a COP21 (que aconteceu em dezembro de 2015 na França). Acompanhar pela primeira vez uma COP - a COP20 - me permitiu identificar os diferentes espaços e entidades presentes no evento, do que resultou o enfoque dado no primeiro capítulo aos aspectos mais pertinentes para contextualizar a elaboração da proposta de RIA.

Entretanto, avaliei que uma descrição etnográfica mais extensa não atendia aos objetivos da pesquisa, pois ficou claro, ao acompanhar a COP20 e as atividades da coordenação da COICA durante o evento, que a COP é o principal espaço para as negociações internacionais oficiais do clima e, portanto, é um espaço significativo para entender uma esfera onde RIA é apresentada; entretanto, não é nesse espaço que a proposta é efetivamente construída. A realização anual das COP representa um momento importante para o encontro e articulação de entidades diversas que trabalham com clima - empresas, organizações da sociedade civil e governos. Entretanto, pela organização do espaço e das atividades, para as organizações da sociedade civil que não tem autorização para acompanhar a maioria das discussões que acontecem fora da plenária principal e dos side-events (que já são eventos voltados para a sociedade civil organizada dentro do espaço oficial), os principais ganhos de estar presente nas COP é firmar articulações com outras organizações e realizar lobby junto aos governos ali representados (uma descrição da participação da COICA na COP20 aparece nos capítulos dois e três).

Para entender a construção da proposta de RIA, seria pertinente acompanhar reuniões promovidas pela própria COICA, ou com sua participação, junto a suas organizações de base e parceiros da sociedade civil organizada. Tive a oportunidade de acompanhar três destas reuniões (sendo as duas primeiras consideradas campos exploratórios pelas datas - 2013 e 2014 -, mas que ajudaram a entender o processo de construção de RIA): a primeira em 2013, o “Taller Regional Cambio Climático, REDD+ y REDD+ Indígena Amazónico" (que aconteceu entre 29 de julho e 02 de agosto em Caiena, Guiana Francesa), último dos seminários de nivelamento sobre 
mudanças climáticas e REDD+ realizados pela COICA nos nove países da bacia amazônica entre 2012 e 2013²; a segunda em 2014, o "1º Encontro REDD+ Indígena Amazônico" (que aconteceu entre 19 e 21 de maio em Rio Branco, Acre), seminário que reuniu representantes das organizações indígenas das cinco localidades em que se acordou implementar as experiências-piloto de RIA para discutir os avanços até o momento; a terceira, em 2015, o "Encuentro de saberes sobre Planes de Vida Plena para los Pueblos Indígenas" (que aconteceu entre 02 e 05 de março de 2015 em Pachacamac, Peru), seminário do qual participaram organizações indígenas e da sociedade civil para discutir a importância da elaboração de Planos de Vida.

Ao desenhar a presente pesquisa, planejava acompanhar a reunião preparatória da COICA para a COP21, realizada todos os anos e que reúne membros de todas as organizações de base da COICA. Havia muita expectativa para esta reunião, considerando que na COP21 as Partes (países) estabeleceriam o novo Acordo Global para o Clima (lançado como Acordo de Paris); por isso, a COICA tinha intenção de realizar uma reunião preparatória maior para apresentar suas propostas no evento. Pela data e pelos participantes (todas as organizações membro da COICA), foi o momento para o qual planejei fazer uma pequena etnografia e as entrevistas não apenas com coordenadores, como com membros das organizações de base. Entretanto, essa reunião foi cancelada às vésperas da data marcada (no final de julho de 2015), sob a justificativa da COICA de falta de recursos para sua realização.

Assim, diante da impossibilidade de realizar esta etapa da pesquisa, foi necessário ajustar parte dos objetivos aos quais a pesquisa procuraria responder. Ao invés de investigar os significados de RIA para as organizações indígenas e como a proposta era apropriada pela COICA e por suas organizações de base (como um discurso contra-hegemônico, como era minha hipótese inicial), voltei-me para a análise do alcance de RIA enquanto discurso na esfera do diálogo intercultural, buscando entender como a proposta de RIA, ao ser enunciada por uma organização indígena, era apreendida pelos interlocutores não-indígenas que fazem parte deste campo de negociações sobre mudanças climáticas. $\mathrm{O}$ foco da análise recai, dessa maneira, sobre a maneira como a COICA atua politicamente por meio da apresentação da proposta de RIA.

\footnotetext{
${ }^{2}$ Parte de um projeto de formação realizado por IPAM e COICA no âmbito da iniciativa Forum on Readiness for REDD+, voltada para a construção de diálogo e capacidades técnicas sobre REDD+.
} 


\section{Introdução}

"Mudanças climáticas" são, por definição, as alterações do clima que podem ser relacionadas à ação humana, no que se diferenciam das variações climáticas, estas sendo fenômenos resultantes das interações entre a atmosfera, os oceanos, o calor e outros fenômenos naturais como erupções vulcânicas ${ }^{3}$ :

"Mudança do clima” significa uma mudança de clima que possa ser
direta ou indiretamente atribuída à atividade humana que altere a
composição da atmosfera mundial e que se some àquela provocada pela
variabilidade climática natural observada ao longo de
períodos comparáveis. (ONU 1992, p.2)

Alguns dados importantes para ilustrar porquê se pode falar de mudanças climáticas foram divulgados em 2007, apontando para o aumento de temperatura terrestre e dos oceanos, mudanças nos padrões de vento e na quantidade de precipitação (padrões de chuva, redução de geleiras, aumento do nível do mar e ocorrência dos chamados eventos climáticos extremos - secas, precipitações extremas, ondas de calor e intensidade de ciclones, tufões e furacões (IPCC 2007, p.11).

Pesquisadores (ver Steffen et al., 2007 para um exemplo) atestam que as mudanças climáticas são uma das provas de que a humanidade passou da era geológica do Holoceno e situa-se na era do Antropoceno, momento marcado pela proeminência da ação humana sobre a Terra em relação aos fenômenos naturais - ou seja, significa que a potência da ação humana, hoje e há algumas décadas, consegue interferir de maneira igual ou mais forte sobre os processos terrestres do que os fenômenos naturais. As mudanças climáticas são uma amostra disso, sendo consequência do aumento de gases de efeito estufa na atmosfera. A concentração de gases de efeito estufa, como dióxido de carbono $\left(\mathrm{CO}_{2}\right)$, metano e óxido nitroso, aumenta a partir de 1750 e é associada principalmente à queima de combustíveis fósseis, que liberam $\mathrm{CO}_{2}$ na atmosfera e às mudanças de uso do solo (por exemplo, abertura de áreas de floresta para cultivo) (IPCC, 2007). Por sua ligação inextrincável com a ação humana, a questão das

\footnotetext{
${ }^{3}$ O IPCC considera como "mudança do clima" qualquer alteração climática observada ao longo de determinado período de tempo, seja ela decorrente da atividade humana ou não (IPCC 2007, p. 3). Para os fins deste trabalho, utilizaremos o termo 'mudanças climáticas' de acordo com a definição da UNFCCC.
} 
mudanças climáticas é, para além de um fenômeno climatológico, físico e ambiental, um fenômeno social.

Apesar de estudos dispersos sobre mudanças climáticas terem se desenvolvido ao longo do século $\mathrm{XX}$, o tema começa a ganhar proeminência a partir da primeira conferência de meio ambiente das Nações Unidas, a Conferência de Estocolmo em 1972 - mesmo ano em que o estudo "Os Limites do Crescimento" é divulgado, como resultado de pesquisas sobre as atividades econômicas e a disponibilidade de recursos naturais do planeta. É a partir de 1988 que o tema de mudanças climáticas passa a adquirir um espaço próprio para além da esfera ambiental, com o estabelecimento do Painel Intergovernamental de Mudanças Climáticas (IPCC na sigla em inglês, de Intergovernmental Panel on Climate Change), um organismo científico criado pelo Programa das Nações Unidas para o Meio Ambiente e pela Organização Meteorológica Mundial, que sistematiza, revisa e avalia produções técnico-científicas sobre mudanças climáticas produzidas no mundo todo ${ }^{4}$. Até meados da década de 1990, portanto, a agenda das mudanças climáticas esteve essencialmente vinculada à agenda ambiental, que teve visibilidade crescente entre as décadas de 1980 e 1990.

A Conferência das Nações Unidas sobre o Meio Ambiente e Desenvolvimento (ECO 92), realizada no Rio de Janeiro em 1992, foi um marco para estas agendas - pela primeira vez, reuniram-se 116 chefes de Estado e cerca de 1.400 organizações da sociedade civil para discutir metas relacionadas a meio ambiente, resultando na elaboração de cinco documentos ${ }^{5}$ (ainda que não tenham status de vinculantes). Um destes documentos é a Convenção-Quadro das Nações Unidas sobre Mudanças Climáticas (UNFCCC, sigla em inglês para United Nations Framework Convention on Climate Change). A UNFCCC tem como objetivo principal estabilizar a concentração de gases de efeito estufa na atmosfera a um nível que assegure a segurança alimentar humana e adaptação dos ecossistemas. Nesse texto, são definidos países do Anexo I (ao todo, são 40 países mais União Europeia e Reino Unido, que são considerados os países 'industrializados', bloco composto pelos países chamados 'desenvolvidos' e 'em

\footnotetext{
${ }^{4}$ O IPCC é composto por três Grupos de Trabalho, sendo que cada um destes grupos produz um relatório sobre os seguintes temas: bases das ciências físicas para as mudanças climáticas; impactos, adaptação e vulnerabilidades às mudanças climáticas e estratégias de mitigação (respostas). Até hoje, foram divulgados cinco relatórios finais de cada um destes Grupos de Trabalho: o primeiro em 1990; o segundo em 1995, o terceiro em 2001; o quarto em 2007 e o quinto entre 2013 e 2014.

5 Agenda 21, Declaração do Rio sobre Meio Ambiente e Desenvolvimento, Princípios para a Administração Sustentável das Florestas, Convenção da Biodiversidade e Convenção sobre Mudança do Clima.
} 
transição') e destacado o papel destes em protagonizar as ações de combate à mudanças climática a partir da noção das "responsabilidades comuns porém diferenciadas" (Artigo 3 - Princípios). A noção das responsabilidades comuns porém diferenciadas refere-se à responsabilidade que todas as Partes que assinam a Convenção tem em relação ao clima do planeta, porém estipulada as diferentes situações socioeconômicas, capacidades tecnológicas e contribuições distintas para a concentração de gases de efeito estufa na atmosfera que caracterizam obrigações diferentes para as Partes. Lê-se nas disposições iniciais da Convenção:

\footnotetext{
Observando que a maior parcela das emissões globais, históricas e atuais, de gases de efeito estufa é originária dos países desenvolvidos, que as emissões per capita dos países em desenvolvimento ainda são relativamente baixas e que a parcela de emissões globais originárias dos países em desenvolvimento crescerá para que eles possam satisfazer suas necessidades sociais e de desenvolvimento. (ONU 1992, p.2)
}

A Convenção ainda designa a COP como instância que objetiva acompanhar a discussão e implementação de ações que visem alcançar os objetivos da UNFCCC. A UNFCCC é entra em vigor em 1994, assinada por 195 países, e a primeira COP ocorre em 1995, sendo realizada anualmente a partir de então. A publicação do segundo relatório do IPCC em 1995 e a elaboração do Protocolo de Kyoto em 1997 são marcos que consolidam o momento em que o tema de mudanças climáticas adquire um espaço próprio para além da agenda ambientalista - ainda estas agendas ainda sejam articuladas.

Em 2007, o quarto relatório do IPCC aponta com maior grau de certeza a ligação entre o aumento da concentração dos chamados gases de efeito estufa na atmosfera e as mudanças climáticas, até então debatidas sob níveis altos de incerteza. Fica evidente, portanto, a associação entre a atividade humana após o período pré-industrial e as mudanças climáticas. A partir do momento em que os dados científicos levam a um questionamento dos fundamentos do sistema capitalista hegemônico (modo de produção industrial, matriz energética e uso do solo), a discussão sobre mudanças climáticas deixa de ser estritamente do campo das ciências naturais, revelando-se o peso político e social destas discussões. 
A dimensão política da questão fica ainda mais evidente na polarização observada nos Estados Unidos (descrita por Palacio, 2013): de um lado, republicanos e empresas petroleiras subsidiando centros de pesquisa que negavam o caráter antrópico das mudanças climáticas (a corrente conhecida por céticos ou negacionistas que mobilizaram parte importante da opinião pública norte-americana entre 2009 e 2011) por exemplo, em 2003, o senador estado-unidense James Inhofe afirma que os relatórios do IPCC são ideológicos e sem rigor científico, fazendo 'juizos de estilo soviético' e servindo aos interesses dos ambientalistas extremistas e anticapitalistas de obter financiamento e poder (em Palacio 2013, p. 60); de outro lado, democratas - Al Gore é uma figura destacada nesse segmento -, institutos científicos europeus e IPCC atestando a influência humana sobre as mudanças climáticas e a urgente necessidade de mudanças significativas para contê-las.

É neste aspecto que a questão das mudanças climáticas mostra-se uma questão iminentemente social, política e econômica: a questão subjacente às discussões sobre mudanças do clima chega, no limite, ao questionamento sobre os paradigmas e práticas que sustentam a sociedade global. O embate entre visões que defendem a ruptura com o sistema hegemônico capitalista e a busca de saídas para a crise climática dentro desse sistema é uma das dimensões que permeia as negociações internacionais sobre o tema.

Entende-se, portanto, as discussões e negociações sobre mudanças climáticas como um campo disputado por determinados sujeitos. É necessário identificar estes sujeitos e em que espaço suas interações se dão. Como exposto, o espaço oficial para a negociação sobre as mudanças climáticas são as COP. As características desse espaço são bastante ilustrativas de um campo político específico: trata-se de um espaço que reúne pessoas de centenas de países, sendo estas chefes e representantes (ministros, assessores, por vezes governadores e deputados, e de diversas áreas da burocracia estatal) de Estados Nacionais, comunidade científica (pesquisadores de institutos de pesquisa e da academia), organizações da sociedade civil (ambientalistas, de direitos humanos, indígenas), instituições multilaterais e agências financiadoras (como o Banco Mundial) e setor privado (empresas especialmente ligadas à energia e transportes); esta diversidade de pessoas estão envolvidas em discussões e negociações que tratam de ações a nível global e cujos acordos de peso (vinculantes) são estabelecidos (quando são) a partir de consensos entre as centenas de Estados nacionais ali presentes; por fim, as COP são um espaço em que a importância das articulações e do lobby entre os 
presentes é determinante para o rumo das negociações. Ainda que os debates, ações e alianças feitas entre os sujeitos que participam das COP extrapolem em muito o evento em si, este é um lugar central e uma referência em torno da qual estes sujeitos se articulam, razão pela qual se pode considerá-lo como o espaço no qual a disputa entre as visões mencionadas aqui se encontram e configuram. Não será possível neste trabalho analisar todos os sujeitos e nem cada um dos segmentos aqui listados em profundidade, pois se entende que nenhum destes segmentos é um monolito; trata-se aqui, na primeira parte desta dissertação, de situar alguns protagonistas de cada um destes segmentos em relação a seus lugares de fala e interlocutores, situando-os em um campo em que as posições são determinadas geopoliticamente e orientadas por um regime discursivo de verdade respaldado por um determinado tipo de conhecimento (científico nos moldes ocidentais).

Paralelamente à globalização do tema de mudanças climáticas, observou-se a emergência da presença dos povos indígenas em articulação a nível global. A identificação entre povos indígenas dos mais diversos lugares do mundo que tem hábitos culturais, contextos políticos, heranças históricas e mesmo cenários ambientais e climáticos muito distintos dá-se, portanto, por compartilharem a situação de marginalidade, impotência e distinção perante as sociedades envolventes. É nas intersecções de suas vulnerabilidades que encontra-se o que Niezen (2003) considera a “essência de como os povos indígenas como comunidades internacionais se definem”.

Os povos indígenas buscam apoio e visibilidade internacional dada sua fraqueza política na escala nacional e regional. A articulação indígena transnacional torna-se cada vez mais necessária e coerente frente a um contexto de problemas igualmente transnacionais, relacionados geralmente à atuação de multinacionais e agentes multilaterais que intervém sobre áreas transfronteiriças:

\footnotetext{
Transnational social movement mobilization is also an appropriate response to increasingly transnational social problems, from development projects sponsored by multinational corporations and multilateral development banks to increasing cultural penetration by missionary groups. (Brysk 1996, p. 43)
}

E qual é o papel dos povos indígenas no campo das mudanças climáticas? Por um lado, os indígenas presentes neste campo são muitas vezes identificados como as vozes que apontam para uma alternativa de relação entre humanidade e natureza, uma solução de ruptura com nossos paradigmas, um urgente modelo a ser seguido. Em um 
momento em que se questiona o papel e influencia dos Estados nacionais, os povos indígenas são vistos, além de "nativos ecológicos" (Ulloa 2004) e alternativa ao modo de vida capitalista, como vivendo em um estado mais harmônico de natureza; se no século XV e XVI o Estado era uma forma de regulação da sociedade importante que preservava a humanidade da barbárie do estado de natureza, hoje o Estado é visto como opressor em relação às liberdades individuais; e os povos sem Estado, os povos indígenas, como possuidores de uma organização social aparentemente mais livre:

\footnotetext{
Este es el hilo conductor que rescató a los indígenas americanos mayoritariamente descritos por mucho tempo como villanos, pero rescatados como héroes y entroncados hoy en día con el ecologismo contemporâneo. Las víctimas del siglo XVI se convirtieron a fines del siglo XVII en nobles salvajes que servían de soporte a una metáfora en que la sociedad en estado de naturaleza expresaba la libertad originaria constrastada con un Estado que expresaba la coerción necesaria pero indeseada.(Palacio 2013, p.65)
}

Por outro lado, quando se observa as reivindicações proferidas pelos representantes indígenas em relação às mudanças climáticas, nota-se que estas se voltam para a garantia das condições necessárias para sua sobrevivência enquanto povos, sem a implicação de que seus modos de vida se estendam para a população mundial. Ainda que atestem a necessidade de mudança do modo de vida predatório, não está presente nas declarações feitas pelos povos indígenas algum indício relacionado à imposição de seu modo de vida à sociedade mundial (diferente dos discursos de Estados quando tratam dos povos indígenas e de sua necessária assimilação às sociedades nacionais).

Apesar de considerados dentro do espaço oficial das COP como parte da sociedade civil organizada, os representantes indígenas presentes neste espaço reiteram a todo momento a especificidade de seu lugar de fala enquanto povos indígenas - ainda que se organizem muitas vezes conjuntamente com outros segmentos, como ONGs. Organizações e redes de organizações indígenas de partes diversas do mundo estão presentes nestas negociações; cabe neste trabalho identificar estas organizações e a relevância de sua participação nestes espaços para suas reivindicações e contexto (capítulo um).

No capítulo dois, é descrita a atuação de uma dessas redes - a COICA -, de maneira que se possa situar o lugar ocupado por um sujeito indígena no campo das negociações sobre mudanças climáticas, buscando compreender de que maneira ocupar 
este campo se insere na trajetória da COICA, como parte do movimento indígena da América do Sul. A presença da COICA nestas negociações, assim como em outras de caráter transnacional, é compreendida, por um lado, do ponto de vista da formação de um movimento indígena mais amplo que atinge a escala global, apontando para transformações na forma de atuação, discursos e interlocutores do movimento indígena. Por outro lado, a incidência da COICA nas negociações internacionais do clima é vista como estratégia de atuação política capaz de ampliar a visibilidade das reivindicações indígenas, na medida em que a organização articula suas pautas à agenda de discussão sobre o clima. É nessa perspectiva que a proposta de REDD+ Indígena Amazônico da COICA é analisada, como recurso discursivo capaz de alcançar os interlocutores nãoindígenas neste campo de debate sobre as mudanças climáticas. Assim, no capítulo três essa proposta é apresentada de maneira a ilustrar a maneira que não apenas a COICA, mas outras lideranças e organizações indígenas apresentam seus posicionamentos de maneira que estes se tornem inteligíveis aos interlocutores não-indígenas.

Considerando que o campo das mudanças climáticas é constituído e legitimado pelo conhecimento científico, cabe perguntar quais são os conhecimentos deslegitimados nesse campo e quais visões de mundo tornam-se, a partir destes conhecimentos, legítimas ou silenciadas. A partir da proposta de REDD+ Indígena Amazônico pode-se compreender em que lugar a formação discursiva elaborada por indígenas se situa no campo das mudanças climáticas; assumo neste trabalho que este lugar prescinde de uma cosmologia distinta da ocidental que é base para os discursos científicos compartilhados nas negociações sobre mudanças climáticas. 


\section{Capítulo 1: Mudanças climáticas: um campo em disputa}

Este é um depoimento de Davi Kopenawa, no qual é apresentada sua visão sobre as mudanças climáticas:

... É assim. Nós, Yanomami, habitantes da floresta, não enchemos a terra de fumaças-epidemias xawara. São os brancos, os napëpë, que contaminam a terra. Esta é minha fala. Eles não parecem se preocupar com isso, mas nós, que vivemos na floresta, sabemos dessas coisas e por isso pensamos assim. Os brancos ficaram muito numerosos e começaram a destruir a floresta, a cortar suas árvores e a sujar seus rios. Eles fabricaram quantidades de mercadorias. Fizeram carros e aviões para andar rápido. Para fabricar todas essas mercadorias, cavaram o chão da terra para arrancar as coisas que estão nas suas profundezas. Assim começaram a propagar muitas fumaças-epidemias xawara por toda parte, estragando a terra.

Por causa disso, as chuvas estão começando a cair de um modo estranho. (...) nós, pajés, que fazemos dançar os espíritos xapiri, cuidamos da terra-floresta, por isso a conhecemos. Não nos perguntamos como os brancos "o que está acontecendo de repente com a terra?" Sabemos que o que está acontecendo de ruim não é por causa de nossa marca nesse chão. Se fosse, a gente tentaria consertar logo.

O antepassado que criou esta floresta, Omama, nos criou também para cuidar dela. Ele não quis que a destruíssemos. Nós somos seus filhos e por isso não podemos estraga-las. (...) Os pajés estão sempre atentos ao seu bem-estar. Quando a floresta está doente, tomam o pó de yãkõana e curam seus males. (...)

Nós Yanomami estamos muito preocupados porque os brancos só pensam em estragar a Terra, só sabem destruir a floresta. Eles não têm amizade por ela, não a querem. Da profundeza do seu chão só arrancam coisas para fabricar suas mercadorias, depois as queimam e o mundo se enche de fumaças que viram doença xawara para todos. A floresta também adoece dessas fumaças, suas árvores morrem, bem como suas águas e seus animais. É assim que entendemos as coisas. Por isso nós Yanomami estamos tão inquietos. Nós perguntamos: "Por que razão os grandes homens dos brancos não falam sabiamente entre eles e continuam querendo maltratar a Terra?" Eles já têm muitas mercadorias, é suficiente! (...)

Por que estamos tão preocupados? Porque nos perguntamos: "Quando todas estas fumaças espessas dos brancos subirem até o peito do céu e os novos trovões começarem a morrer, o que será da floresta?" é por isso que ficamos inquietos. Não existem remédios para curar a Terra e para que ela fique boa de 
novo. Se vocês brancos matam a floresta, vocês não vão ser capazes de fabricar outra, nova. Quando todas essas coisas brilhantes que vocês arrancaram da terra, o outro, os diamantes, os minérios e também as coisas de fazer fogo [combustíveis], e todas as árvores, quando tudo isso acabar, a Terra vai ficar morta.

Damos essas palavras para que abram caminho na sua frente, como advertência. Esperamos que, com elas, vocês tornem-se mais atentos, mais espertos. Vocês devem parar de maltratar a Terra. Não podem continuar destruindo-a dessa maneira desenfreada! Quem a criou vai acabar ficando com raiva. A imagem dele existe ainda, seu fantasma existe ainda no mundo. Se ele acaba se zangando, vocês vão sofrer. (...)

Nós que vivemos nela sabemos dessas coisas da floresta. Vemos quando os dias não amanhecem bonitos e ficam cheios de fumaça. Vemos, durante a noite, quando a lua também fica enfumaçada e avermelhada. A chuva cai muito pouco. Mas, depois, na lua seguinte de repente cai muito forte, sem parar. A floresta mostra sua raiva; de maneira súbita, ela quer secar e queimar ou se cobrir de água. Nós, pajés, devemos então trabalhar para ajuda-la e para conter sua raiva. Só quando se quieta podemos morar nela sem perigo, nós e os brancos também. (...) Mas se acabamos todos devorados pelas fumaçasepidemias da xawara, a Terra ficará com raiva. Então, os espíritos do vento da tempestade e dos trovões vão se vingar com muita força. É assim. A mente dos brancos é muito esquecida, por isso produzem todas essas fumaças perigosas da mudança climática e nos deixam viver nessa inquietação. (...)

São estas minhas palavras. Uma vez escritas, espero que todas as pessoas que as ouvirem possam pensar: "Sim! Assim falam os filhos dos [antigos] habitantes da floresta! Essas são suas verdadeiras palavras! Não são eles que criaram essa coisa de mudança climática, é a nossa própria pegada no chão da Terra! Nós carecemos mesmo de sabedoria!" Se assim falarem entre eles depois de ver esses desenhos de palavras, ficarei feliz. Assim foi a minha fala, acabou. (Kopenawa 2011, p.20-23)

\subsection{Por que estudar mudanças climáticas nas Ciências Sociais?}

En todo el caso el poder de confusión o de cuestionamento de la ciência del cambio climático ha sido poderoso y la batalla por el control de la realidade ya no está ubicada solo en los modelos, el rigor, el instrumental, los laboratorios, los satélites y las instituciones de los científicos, sino en una opinión pública fuertemente financiada por intereses económicos y políticos. (Palacio 2013, p. 61) 
Se nas últimas três décadas do século XX (1970-2000) a questão ambiental ganhou visibilidade e valorização - inclusive em termos financeiros -, este grande impulso não foi suficiente para assegurar a manutenção dos ecossistemas e florestas nativos. Este impulso foi crucial para, por exemplo, a criação de Áreas Protegidas no Brasil (Unidades de Conservação e Terras Indígenas); na América do Sul como um todo, observou-se, especialmente a partir dos anos 1980, o reconhecimento de territórios indígenas e sua titulação, que podem ser considerados parte desse impulso próambientalista. Entretanto, estas áreas e seu entorno encontram-se sob constante ameaça de devastação e invasões constantes, indicando que mesmos os esforços pelo reconhecimento e proteção destas áreas mostram-se insuficientes frente aos desafios para o alcance de soluções para os problemas ambientais. A partir da visibilidade para a questão ambiental, a agenda climática ganha crescente atenção na comunidade internacional.

Os desafios de lidar com a questão de mudanças climáticas são inúmeros: da necessidade de ação em escala global às incertezas advindas de tratar-se de uma ameaça futura - o que coloca o questionamento sobre a efetividade dos impactos previstos relacionados às mudanças climáticas. Nesse aspecto em especial, o fato de as mudanças climáticas não serem no momento presente palpáveis cria resistências diversas para a tomada de ação, que Giddens (2010, p. 21) elenca como: a distância no tempo (a falta de urgência que faz deixar para depois), a negação (questionamento sobre a legitimidade científica), a inação localizada (a resistência de um indivíduo ou grupo em agir a não ser que os outros indivíduos ou grupos todos ajam), a descrença na efetividade das ações pontuais e mesmo a urgência de outros problemas mais tangíveis tornam a discussão e implementação de ações relacionadas à mudanças climáticas em geral secundárias, tanto na esfera individual quanto coletiva nas diferentes escalas (local a global).

Pela complexidade das questões ambiental e climática em termos da tomada de decisão e ação, na medida em que exigem um tipo de ação de caráter global e o envolvimento de sujeitos diversos - de governos em diferentes escalas, do setor privado, da sociedade civil e das instituições multilaterais (tomando-se estes sujeitos como grandes grupos) -, bem como por seu caráter transnacional, existem muitos pontos em comum entre a chamada governança global e estas agendas do ponto de vista das relações internacionais (Milani 1999). Discute-se a governança global no contexto em 
que se reconfiguram os papéis de organizações estatais e não-estatais nas esferas de regulação política nacionais e mundial; a partir da reflexão sobre a articulação entre Estados e mercado e sobre a crise de governabilidade dos Estados.

\begin{abstract}
Nesse contexto, o tema da governabilidade, ou da governança global, tem estado no centro das discussões acerca dos novos paradigmas da ordem mundial e do futuro das relações internacionais. Tenta-se reconstruir a ordem com base na noção de governança, cujo mérito principal está certamente no reconhecimento da complexidade do sistema. No entanto, a literatura atual sobre a governança se encontra no centro de disputas ideológicas e não logra aprofundar o pensamento epistemológico essencial acerca das origens e eventuais diferenças entre governança e ordem, governança e regime, governança e mercado. (Milani 1999, p.99)
\end{abstract}

Basicamente, dois fatores são pilares para a formulação do termo governança e sua aplicação: a predominância das práticas internacionalizadas de mercado capitalistas e a globalização dos sistemas de informação. Segundo Camargo (1999),

\begin{abstract}
... a noção de governança partiu de uma análise da crise de governabilidade da instância estatal e da diminuição de eficiência e eficácia da ação pública. A idéia central, a partir desta perspectiva, é de que em um mundo de complexidade crescente e de uma diferenciação, também crescente, de subsistemas, o Estado é impotente para prever a consequência de suas ações e, portanto, para ditar normas e aplicá-las, tornando-se incapaz de responder às demandas da sociedade. (p.11)
\end{abstract}

A partir dessa crise de governabilidade dos Estados, colocam-se duas correntes: uma neoliberal, que valoriza os sujeitos do setor privado e um modelo de governança baseado no modelo empresarial; e outras críticas à primeira que defendem a transnacionalização ${ }^{6}$ da dimensão política em vários níveis e escalas, a serem ocupadas por sujeitos diversos, concebendo o sistema internacional como uma estrutura plurilateral composta por outros tipos de representações e unidades políticas para além dos Estados nacionais, como organizações, associações e redes.

Considerando a multiplicidade de visões sobre governança (vide Milano, 1999), tomaremos aqui considerações sobre governança ambiental a partir de uma perspectiva das Ciências Sociais apresentada em publicação organizada pelo Conselho Latinoamericano de Ciências Sociais por Castro, Hogenboom e Baud, "Governança ambiental na América Latina” (2015). Essa perspectiva se contrapõe à visão de governança mais difundida apregoada pelo Banco Mundial (que converge com a perspectiva neoliberal) -

\footnotetext{
${ }^{6}$ Neste trabalho utilizarei o termo 'internacional' para caracterizar instâncias e organizações cuja influência se estenda a vários países (as Conferências da ONU, por exemplo); o termo 'transnacional' será utilizado para definir organizações e ações que ultrapassam as fronteiras nacionais articulando mais de um país (uma ação transnacional ou uma organização transnacional como a COICA).
} 
Estado mínimo, incentivo aos mercados (liberalização) e descentralização -, focando nas interações sociais que influenciam mudanças institucionais e, em tratando-se de meio ambiente, nas tensões que se colocam entre objetivos conflitantes de desenvolvimento e proteção ambiental. A definição de Castro, Hogenboom e Baud (2015) de governança ambiental é o "processo de formulação e disputa de imagens, esquemas e execução dos procedimentos e práticas que configuram o acesso, o controle e o uso dos recursos naturais entre diferentes atores." (p. 18) Entendendo a governança ambiental como processo social que é vinculado ao contexto histórico, social e político e resultado de interações com a natureza, determinado por uma concepção do que é natureza, o enfoque que as Ciências Sociais trazem para a questão é sobre como as práticas, acordos e mecanismos relacionados ao tema ambiental (e das mudanças climáticas como parte deste) são informados por "diferentes conjuntos de princípios, valores e imagens da natureza, conservação e desenvolvimento" (idem, p. 24). Percepções, valores e discursos sobre o que é a natureza são os fundamentos sobre os quais as relações com esta se formam e que configuram, consequentemente, a governança ambiental. Assim, a interação - muitas vezes, disputa - entre sujeitos no que podemos chamar de governança ambiental passa por um embate entre visões de mundo que vão definir as percepções sobre a relação entre humanos e meio ambiente - incluindo outras formulações, termos e significados para essa relação.

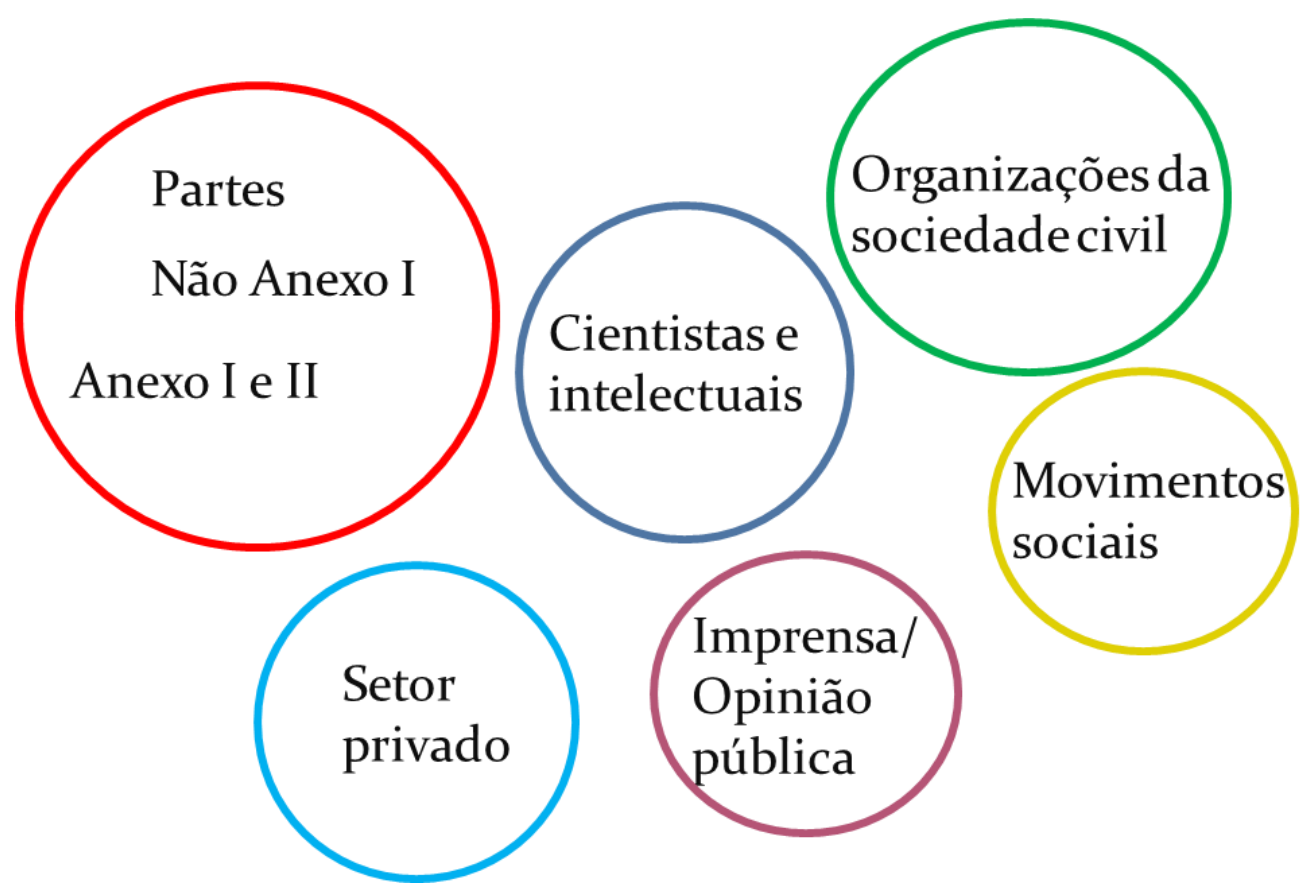

Figura 1. Sujeitos que influenciam as negociações sobre o clima 
1.2 Polarizações no campo das mudanças climáticas

Em relação à diferença de visões no campo das mudanças climáticas, o Protocolo de Kyoto evidenciou algumas tendências conflitantes latentes entre as Partes que compõem a UNFCCC, divididas em Anexo I e o resto, não-Anexo I (partes descritas na Introdução), no que se refere aos compromissos que deveriam ser assumidos pelos países do Anexo I: a redução de 5\% das emissões de gases de efeito estufa até o período 2008-2012, tomando como base o volume de emissões de 1990. O Protocolo não prevê metas para os países que não fazem parte do Anexo I, entendendo que estes tem contribuição significativamente menor em termos de emissões para a concentração de gases de efeito estufa na atmosfera, retomando a noção de responsabilidades comuns porém diferenciadas descrita nas disposições iniciais da UNFCCC:

Observando que a maior parcela das emissões globais, históricas e atuais, de gases de efeito estufa é originária dos países desenvolvidos, que as emissões per capita dos países em desenvolvimento ainda são relativamente baixas e que a parcela de emissões globais originárias dos países em desenvolvimento crescerá para que eles possam satisfazer suas necessidades sociais e de desenvolvimento. (ONU 1992, p. 3)

Os questionamentos colocados pelos países de fora do Anexo I a partir de então, em relação à ausência de compromisso dos Estados Unidos com o Protocolo de Kyoto até o Acordo de Copenhagen, deixam poucas dúvidas em relação à predominância dos aspectos políticos e econômicos da discussão sobre mudanças climáticas em relação ao aspecto científico - se for possível fazer essa dissociação, pretendida pelos cientistas. Neste trabalho, trata-se de destacar, como já feito por outros autores, a inextrincabilidade destas dimensões: científica, política, econômica e social.

... el cambio climático es un proceso social, no sólo en cuanto a las causas e impactos vinculados a la organización industrial de la actividad humana, sino también y, especialmente, en las formas en que distintos grupos han representado estos cambios como un problema de proporciones globales y a las estrategias asociativas para actuar sobre él. (...) Por lo tanto también aspiramos a entender lo social no como algo externo al proceso científico, sino que debemos identificar las prácticas científicas como producto de interacción y negociación social. En el diálogo social sobre cambio climático no basta con "incorporar" la visión de los científicos, sino que éstos deben asumir que el principio de objetividad no elimina el carácter político de las decisiones que deben tomarse sobre la materia. Es necesario avanzar hacia un nuevo rol de la ciencia y reconocer que los científicos no son entes neutrales que generan información pura, sino que la intencionan en cuanto participan de eventos, instituciones y diálogos sociales en los que se debate sobre la dirección de los cambios. (Blanco e Fuenzalida, 2013, p. 91) 
$\mathrm{Na}$ disputa por práticas e ações legítimas no campo específico das mudanças climáticas, é possível identificar algumas polarizações:

1. Países do Anexo I e países não Anexo I: à vista da necessidade de reduzir emissões de gases de efeito estufa colocada, os países do Anexo I colocam resistência maior ou menor em adotar estratégias efetivas dentro de suas fronteiras, defendendo mecanismos que possibilitem o investimento em ações que reduzam emissões em outros países como parte da contabilidade de redução de emissões próprias; os países em desenvolvimento, por sua vez, cobram a noção de responsabilidades históricas e diferenciadas entre países desenvolvidos e em desenvolvimento, ou seja - que os países que se consolidaram suas estruturas produtivas em modelos altamente emissores de gases de efeito estufa tem maior responsabilidade pela situação atual de mudanças climáticas e que, portanto, devem ser responsáveis pela maior parte das tentativas de solução do problema, ou seja, das metas de redução de gases de efeito estufa.

2. Neodesenvolvimentistas ou Economia Verde X "Bem Viver" (de acordo com denominação feita por Castro, Hogenboom e Baud, 2005:21). A corrente neodesenvolvimentista propõe saídas a partir das instituições existentes e da adoção de tecnologias que permitam uso mais eficiente dos recursos naturais, assumindo que inclusive as desigualdades de acesso a estes recursos possam ser aprimoradas e resultarem em modelos mais igualitários a partir de reformas. Já o "Bem Viver" coloca uma perspectiva crítica à manutenção das instituições, sendo necessária a ruptura com o sistema social, político e econômico existente para alcançar uma solução real para a crise climática:

Propõem uma perspectiva de governança ambiental a partir das bases, e pouco ortodoxa, que reivindica uma transformação, ou até mesmo o fim do modelo capitalista hegemônico, considerado como a causa da degradação ambiental e da injustiça. Seus defensores afirmam que o neodesenvolvimentismo e sua conexão com a Economia Verde significam apenas uma nova embalagem para velhos modelos de desenvolvimento, visando manter as relações de poder desiguais em múltiplas escalas. (Castro, Hogenboom e Baud, 2015:22) 
As críticas ao Bem Viver são, de um lado, justificadas pelos que dizem que a solução anticapitalista é impraticável hoje; e de outro, pelos que apontam as contradições dos 'exemplos' de Bem Viver da Bolívia e do Equador como formas de manutenção de estados desenvolvimentistas e extrativistas com uma nova roupagem (no limite, trata-se de crítica similar à que os defensores do Bem Viver como solução para a crise climática fazem à ideia de Economia Verde).

Uma ilustração das duas polarizações descritas acima no campo das Ciências Sociais é observada na diferença das visões entre pesquisadores latino-americanos do Consejo Latinoamericano de Ciencias Sociales - CLACSO (Castro, Hogenboom e Baud) e Giddens, sociólogo britânico. Para o último é preciso trabalhar com o que já existe, sendo mudanças radicais pouco realistas:

\footnotetext{
Muitos dizem que lidar com as mudanças climáticas é um problema difícil demais para ser tratado dentro dos limites da política ortodoxa. Até certo ponto, concordo com eles, pois serão necessárias mudanças muito profundas em nossas formas de pensamento político já estabelecidas. Não obstante, temos de trabalhar com as instituições existentes e de modos que respeitem a democracia parlamentar. (Giddens 2010:23),
}

Os primeiros se aproximam da perspectiva que aponta para a necessidade de uma ruptura sistêmica para encontrar soluções efetivas para a crise climática:

\begin{abstract}
O modelo de Economia Verde supõe que as deficiências, tais como as relações assimétricas, as injustiças e o comportamento não sustentável, podem se transformar em resultados mais igualitários e sustentáveis por meio de um projeto institucional apropriado. (...) O pragmatismo desse enfoque encontra terreno fértil entre os grupos de elite, já que aborda os dilemas da equidade, do desenvolvimento sustentável e da conversação, dentro de uma estrutura capitalista baseada no mercado. (Castro, Hogenboom e Baud, 2015:22)
\end{abstract}

\title{
1.2.1 Países do Anexo I versus Países não-Anexo I
}

No caso dos países sul-americanos, o argumento das mudanças climáticas cabe para vários questionamentos em relação a práticas imperialistas e hegemônicas dos países do Norte - de uma maneira conveniente, o tema de mudanças climáticas entra em discursos políticos de diversas maneiras, inclusive para criticar as disparidades entre países, vide a fala de Evo Morales (presidente da Bolívia) quando considera o 
ambientalismo como nova forma de colonialismo (in Palacio 2013, p. 62), ou discurso de Juan Manuel Santos (presidente da Colômbia):

\begin{abstract}
Podríamos decir que la naturaleza se ha ensañado com nosotros, pero no sería justo. Porque la naturaleza no hace otras cosas que devolver el inmenso daño producido por la desídia de muchos países que no han querido controlar sus emisiones contaminantes. (Santos 2010 in Palacio 2013, p. 52)
\end{abstract}

O principal argumento dos países não-Anexo I para não assumir compromissos de redução de emissões de gases de efeito estufa e cobrar estes compromissos dos países desenvolvidos/industrializados é o das responsabilidades históricas dos segundos - se os países hoje industrializados começaram a aumentar o volume de emissões ainda no final do século XIX, este processo foi iniciado mais de meio século depois nos países em desenvolvimento (processo este associado especialmente à independência dos países da América e da África que eram colônias). Portanto, os países deste grupo afirmam que, ainda que seu volume de emissões associado à queima de combustíveis fósseis tenha crescido consideravelmente nos anos 2000 - sendo que o volume de emissões a partir de 2006 de China e Índia superou os índices de Estados Unidos e Japão respectivamente (dados em Guevara e Zandvliet, 2013) -, o caráter cumulativo das emissões de gases de efeito estufa coloca os países industrializados como os maiores responsáveis pelas altas concentrações destes na atmosfera hoje. O fato de a China ter superado o volume de emissões advindas da queima de combustíveis fósseis inclusive dos EUA e da Índia ter aumentado consideravelmente este volume tornou-se um ponto de embate entre os grupos da UNFCCC: de um lado, os países do Anexo I cobram que os países nãoAnexo I também assumam compromissos, uma vez que atualmente são também países emissores $^{7}$; de outro lado, os países não-Anexo I negam-se a assumir compromissos reafirmando a questão das responsabilidades históricas dos países do Anexo I, amparados pelos dados referentes às emissões acumuladas ao invés de utilizar os dados de emissões anuais de gases de efeito estufa. Isto porque, entre 2006 e 2010 o volume de emissões anual de países desenvolvidos e em desenvolvimento praticamente se equiparou; entretanto, se for considerado os volumes das emissões de gases de efeito estufa acumulados historicamente, os países do Anexo I em conjunto são responsáveis

\footnotetext{
${ }^{7}$ Sobre as contradições dos países em desenvolvimento em relação a posicionamentos internos e externos, ver Palacio (2013), que critica a retórica oportunista do sul, afirmando que os governantes, baseados na teoria da dependência, se isentam dos feitos nacionais e regionais que contribuem para o agravamento da crise ambiental e climática.
} 
por um volume de emissões três vezes maior que o volume referente ao conjunto dos países não-Anexo I (dados apresentados em Guevara e Zandvliet, 2013).

Existem dois argumentos não considerados oficialmente pela UNFCCC que reforçam o posicionamento dos países em desenvolvimento ao defender as responsabilidades comuns porém diferenciadas e a demanda por apoio financeiro e transferência de tecnologia por parte dos países desenvolvidos, que são apresentados por Guevara e Zanvliet (2013): em primeiro lugar, considerar o volume de emissões de gases de efeito estufa per capta, ao invés dos valores absolutos; em segundo lugar, considerar não apenas as atividades produtivas dos países, mas também seus índices de consumo. Calcular o volume de emissões de gases de efeito estufa em relação à população dos países significa, para os autores, considerar o tamanho da população efetivamente beneficiada pelas atividades que consomem combustível fóssil e agravam a condição climática do planeta; ou seja, significa colocar na balança os benefícios gerados por estas atividades em relação aos prejuízos em termos da quantidade de pessoas beneficiadas e prejudicadas. Ao fazer essa conta, a discrepância entre países do Anexo I e não-Anexo I agrava-se, uma vez que os países do segundo grupo são muito cinco vezes - mais populosos que os do primeiro. Os índices de emissões nacionais de gases de efeito estufa (anuais ou acumuladas) per capta revelam números muito diferentes em relação aos valores de emissões nacionais de gases de efeito estufa sem considerar o tamanho da população: se a partir dos anos 1990, a média da emissão dos países do Anexo 1 é em torno de 11tm/ano/capta, a média dos países não-Anexo I é de 2,7tm/ano/capta. Além disso, considerar os índices de consumo - apesar da dificuldade da contabilização - é importante porque nas últimas décadas houve um deslocamento das atividades produtivas dos países desenvolvidos para os países em desenvolvimento. Assim, enquanto os maiores consumidores encontram-se nos países do Anexo I, as fábricas responsáveis pelos produtos consumidos em outras partes do mundo estão localizadas fora de suas fronteiras nacionais - especialmente na China -, pelos custos reduzidos (disponibilidade de recursos naturais e mão de obra explorada). Os custos ambientais destas atividades - incluindo as emissões de gases de efeito estufa - ficam por conta dos países em desenvolvimento que assumem a produção de determinados bens, apesar de muitas vezes a maior parte dos consumidores destes bens morar em outros países. 
Ambos os argumentos respaldam a afirmação de que os benefícios do modelo de produção capitalista consolidado pelos países industrializados beneficia uma população reduzida se comparada ao total mundial, enquanto os impactos prejudiciais resultantes deste modelo são compartilhados entre todos. Neste ponto, ainda, os países não-Anexo I e os movimentos sociais reforçam que os impactos são ainda mais prejudiciais para suas populações, pois agravam condições já existentes de pobreza e marginalidade:

\begin{abstract}
Aunque los países en desarrollo no lo causaron, serán quienes más sufrirán sus efectos debido, entre otras cosas, a la falta de recursos, la baja capacidad institucional y a la dependencia de sus economías de rubros más sensibles al clima como la agricultura. De hecho ya se prevén serias alteraciones de la seguridad alimentaria que empeorarán las condiciones de vida en la mayoría de los países en desarrollo. (Guevara e Zanvliet, 2013:39)
\end{abstract}

\title{
1.2.2 Reivindicações por justiça climática
}

Para Palacio (2013), não existe ambientalismo sem justiça social; quando um é desvinculado do outro, o ambientalismo pode resultar no fortalecimento de elites e em ações de exclusão - tome-se como exemplo o conflito entre o reconhecimento de áreas protegidas no formato de parques nacionais (sem populações que os habitem) e o reconhecimento de territórios ocupados por povos tradicionais, considerado um conflito resultante da distorção excludente que o ambientalismo conservacionista pode gerar. Assim, as soluções ambientais - e consequentemente climáticas - devem necessariamente incluir propostas que tratem das crises sociais resultantes do mesmo modelo que criou os problemas ambientais.

Em la medida que los temas de cambio climático copan el interés de agencias poderosas de financiación, algunos pocos ambientalistas de vieja data y otros recién llegados migran hacia la preocupación por el carbono, el villano principal del cambio climático. Se trata de un viraje oportunista. La crisis ambiental contemporânea desborda con mucho el cambio climático global y hace parte de una agenda de transformación social que muchas veces no ha hecho el esfuerzo de hacer sinergia con las luchas sociales populares. (Palacio, 2013, p. 68)

Aqui vemos intersecções entre argumentos dos países em desenvolvimento - o das responsabilidades históricas - e o clamor dos movimentos sociais por justiça climática. Tanto o argumento dos países em desenvolvimento quanto dos movimentos por justiça climática partem da afirmação de que os países desenvolvidos são os maiores 
responsáveis pela crise climática, devendo ser portanto os que devem arcar com os custos para reparar essa situação (Mendoza 2009, p. 31).

A mobilização em prol da justiça climática começou em 2000, em reunião paralela à COP6, reunindo cerca de 500 lideranças de organizações sociais e ambientais (Mendoza 2009), afirmando que a questão das mudanças climáticas é uma questão de direitos humanos. Desde então, ocorreram encontros que reuniram centenas de organizações da sociedade civil (em 2002, 2004, 2007, 2009, em diferentes partes do mundo - Europa, África, América do Sul e América Central), e cujos documentos produzidos e discussões colocavam, em linhas gerais, que a discussão das mudanças climáticas é uma discussão social e ética. Em seus apontamentos (sistematizados em Mendoza 2009; Justicia Climatica Ya 2004), destacam que as soluções baseadas em mecanismos de mercado, como o mercado de carbono, não são efetivas, e sim arranjos para manter as atividades baseadas em queima de combustíveis fósseis promovidas pelas grandes corporações e protegidas pelas instituições financiadoras e países delas dependentes. Criticam estes mecanismos como formas de mercantilizar a natureza e transformá-la em lucro, mas que não trazem reais contribuições para o problema climático. Apontam para a dívida ecológica histórica dos países desenvolvidos - da qual resultam danos aos ecossistemas e à vida humana -, para a finitude dos recursos naturais, para a insustentabilidade do atual sistema e para a desigualdade socioeconômica promovida por este, que deve ser combatida de maneira indissociável da questão climática. Em 2009, na Bolívia, foi realizado o Tribunal Internacional de Justiça Climática, que reuniu organizações indígenas 'e ativistas' para denunciar casos de negligencia de Estados nacionais e impactos de atividades de empresas para populações locais e seus territórios e ecossistemas. Dentre os casos apresentados, a Iniciativa para Integração Regional Sul-Americana (IIRSA) foi um deles, questionando os impactos das obras de infraestrutura e as instituições financiadoras desta. O intuito do Tribunal foi apontar para os problemas e ameaças já colocados para diversas populações que serão agravados pelas mudanças climáticas: pobreza, insegurança alimentar e marginalidade.

A partir das questões colocadas pelos movimentos sociais por justiça climática, ficam evidentes alguns questionamentos: como, para cada Estado nacional, é possível combinar o discurso ambiental/climático com a agenda do desenvolvimento? Quando países em desenvolvimento como a Bolívia posicionam-se nesse debate, como justificar 
as decisões de governo relacionadas à exploração petrolífera, minerária, ou mesmo aos impactos de obras de infraestrutura? Como especialmente esses países, como o Brasil, podem pleitear recursos internacionais para ações de redução de emissões (no caso do Brasil, relacionadas à redução do desmatamento) e manter outras atividades altamente emissoras em outros setores? Essas aparentes contradições indicam que existem ainda mais questões de fundo a serem exploradas no campo de discussões sobre as mudanças climáticas. Do quarto relatório do IPCC (2007) para o último (2014), observou-se precisamente a pouca eficácia das ações em termos de redução de emissões de gases de efeito, o que significou atestar que os cenários de aumento de temperatura se tornam mais próximos e para temperaturas mais altas; e a mudança de enfoque para a adaptação, necessária em menor tempo e diante da pouca eficácia das negociações com enfoque na mitigação. Ou seja, qualquer que tenha sido o caminho adotado até o momento em busca de mitigar as mudanças climáticas, este caminho não tem se mostrado eficaz. Esta é uma das razões pelas quais parece que apostar nas regulações internacionais e nos mecanismos de mercado que levem a tecnologias mais limpas e mudanças de padrão de consumo, como sugerem os neodesenvolvimentistas, não parece levar ao equilíbrio climático. Assim, este trabalho se aproxima da perspectiva dos que se posicionam em favor do "Bem Viver", entendendo a crise climática como desdobramento de uma crise ambiental mais ampla e relacionada às estruturas sociais, econômicas e políticas vigentes.

1.3 Mecanismos institucionalizados nas negociações internacionais: mais elementos em disputa

O Protocolo de Kyoto prevê mecanismos auxiliares para que os países do Anexo I atinjam suas metas de redução de emissões de gases de efeito estufa, conhecidos como "mecanismos de flexibilização": o Comércio de Emissões, a Implementação Conjunta e o Mecanismo de Desenvolvimento Limpo (MDL), voltado para os países que não fazem parte do Anexo I, como forma de reduzirem suas emissões fora de compromissos estabelecidos. O Comércio de Emissões permite que os países que devem assumir compromissos de redução de emissões podem negociar excedentes de redução entre si como forma de complementar suas ações de redução, ou seja, um país que reduza suas emissões de gases de efeito estufa além de sua meta pode comercializar o excedente 
com outro país que não tenha alcançado sua própria meta (conforme Artigo 17 do Protocolo de Kyoto). O mecanismo de Implementação Conjunta permite que um país atinja parte de sua meta ao implementar um projeto de redução de emissões em outro país que também seja parte do Anexo I; por fim, o MDL prevê a redução certificada de emissões de gases de efeito estufa por meio de ações e projetos em países que não fazem parte do Anexo I; as ações implementadas em países de fora do Anexo I via MDL podem ser apoiadas/financiadas por países do Anexo I e assim serem contabilizadas como parte de seus esforços para redução de emissões.

REDD+ (Redução Compensada de Emissões por Desmatamento e Degradação Florestal, e ações de conservação, manejo sustentável das florestas e de aumento dos estoques de carbono florestal) é um mecanismo de compensação que se insere na lógica do MDL, destinado a grupos ou estados/municípios/países que contribuam para a manutenção dos estoques de carbono contidos em florestas por meio de sua conservação, recuperação ou manejo sustentável. Discute-se a implementação deste mecanismo desde 2005 nas COP, sendo que sua regulamentação e implementação (padrões de medição e verificação da redução de emissões, distribuição equitativa de benefícios, fontes de financiamento e salvaguardas socioambientais) ainda são alguns dos temas polêmicos que não foram acordados entre os países. Sob o argumento de que a contribuição destas florestas é importante para o equilíbrio climático e que, por outro lado, a manutenção destas áreas no contexto dos países em desenvolvimento representa um custo, é acordada na COP13 (2007) a inclusão do REDD como mecanismo internacional (Pinto et al., 2010). Entre 2005 e 2012, o conceito de REDD foi se expandindo; inicialmente, tratava-se da compensação pela redução de desmatamento; progressivamente foram incluídas mais ações que poderiam ser compensadas, como evitar a degradação florestal e as 'ações positivas', como ações voltadas para a conservação, o aumento de áreas de floresta e o manejo sustentável. O acréscimo destas ações ao mecanismo de REDD fez com que se acrescentasse o "+" ao nome, que hoje é conhecido como "REDD+". O desenvolvimento do conceito é, portanto, fruto do trabalho de pesquisadores de instituições públicas e do terceiro setor e de discussões que envolvem representantes oficiais de países, da sociedade civil organizada e da iniciativa privada.

REDD+ é uma proposta defendida por países de fora do Anexo I, institutos de pesquisa e organizações da sociedade civil. Na configuração geopolítica das mudanças 
climáticas, localiza-se na perspectiva “do Sul”, mas que atende à corrente menos radical da polarização sobre mudanças climáticas, ou seja, da corrente pertencente à esfera das negociações internacionais que discute mecanismos dentro do sistema capitalista para a mitigação e adaptação às mudanças climáticas.

Mas considerando que a parte mais significativa das emissões de gases de efeito estufa vem das atividades associadas à queima de combustíveis fósseis realizadas pelos países do Anexo I, por que insistir em um mecanismo que trata da redução do desmatamento e degradação florestal, ainda que a mudança de uso do solo também seja um fator que contribui de maneira relevante para as mudanças climáticas?

\begin{abstract}
Medidas que caibam no sistema econômico vigente obtêm maior sucesso do que aquelas que questionam o sistema energético baseado em combustíveis fósseis. (...) As emissões provenientes do desmatamento representam cerca de um quinto das emissões totais (IPCC, 2007). O grande foco sobre esse setor e seu papel fundamental para solucionar a equação da mudança climática está intrinsecamente relacionado ao fato das reduções de emissões florestais serem mais "baratas" de se obter, tanto do ponto de vista econômico quanto político. (Carvalho 2010: 108)
\end{abstract}

Tanto movimentos sociais quanto países de fora do Anexo I criticam os mecanismos flexíveis por considerarem que estes possibilitam aos países do Anexo I reduzir suas emissões de gases de efeito estufa sem realizarem mudanças estruturais em seus modos de produção e matriz energética dentro de suas fronteiras nacionais, transferindo essa responsabilidade a outros países e, portanto, não cumprindo com o compromisso e esforços globais que devem ser feitos para estabilizar o clima. Ainda assim, a ratificação do Protocolo de Kyoto gerou bastante resistência para países do Anexo I, não sendo ratificado pelos Estados Unidos, um dos principais emissores mundiais de gases de efeito estufa. $\mathrm{Na} 15^{\circ} \mathrm{COP}$, em 2009 , ano em que as metas de redução de emissões já deveriam estar perto de serem atingidas, os Estados Unidos colocam uma proposta aceita na Convenção pelo Acordo de Copenhagen, que permite aos países elaborarem suas próprias metas de redução de emissões de gases de efeito estufa, ao invés de assumirem metas previstas externamente (como pelo Protocolo de Kyoto).

1.4 Visões sobre mudanças climáticas: geopolítica do conhecimento

$\mathrm{Na}$ medida em que as ações humanas mencionadas, identificadas como causas das mudanças climáticas, são basilares para o sistema de produção capitalista que se 
consolidou a partir da Revolução Industrial, o debate em torno das mudanças climáticas é, em realidade, o debate sobre as estruturas sociais e paradigmas de desenvolvimento, precisamente em um contexto em que o discurso sobre "desenvolvimento" ganha centralidade como problema mundial (após considerada superada a etapa de "busca pela civilização" por parte da humanidade, considerando o pós-segunda guerra mundial). O debate em torno do paradigma do desenvolvimento assume, então, uma dimensão epistemológica. Escobar (1995) situa a construção do "desenvolvimento" enquanto discurso de dominação e "crença" que engendra uma série de práticas em todo o mundo, desnaturalizando este conceito, colocando em perspectiva suas premissas e direcionamento ao apontar para o processo em que esse discurso se constitui como dominante e delimita a maneira como a realidade é vista e construída a partir dele:

... I propose to speak of development as a historically singular experience,
the creation of a domain of thought and action, by analyzing the
characteristics and interrelations of three axes that define it: the forms of
knowledge that refer to it and through which it comes into being and its
elaborated into objects, concepts, theories, and the like; the system of power
that regulates its practice; and the forms of subjectivity fostered by this
discourse, those through which people come to recognize themselves as
developed or undeveloped. The ensemble forms found along these axes
constitutes development as a discursive formation, giving rise to an efficient
apparatus that systematically relates forms of knowledge and techniques of
power. (p. 10)

Da mesma maneira, o tema "mudanças climáticas" é formulado, debatido e negociado a partir de uma perspectiva hegemônica, de termos e a partir de premissas que são produto de uma determinada visão de mundo - eurocêntrica e capitalista. A disputa nesse campo se dá em várias esferas, porém existem distinções entre essas disputas, pelo menos duas: a disputa entre sujeitos capitalistas que ocupam posições diferentes no sistema-mundo (por exemplo, entre países capitalistas desenvolvidos e não-desenvolvidos; entre organizações da sociedade civil e governos nacionais) e entre sujeitos que, inseridos ou não na estrutura capitalista, questionam as bases desse sistema e da visão de mundo que o engendra (movimentos sociais versus governos nacionais; organizações da sociedade civil que defendem a adoção de soluções de mercado versus organizações da sociedade civil que são contra soluções de mercado $^{8}$ ). No caso dos sujeitos que questionam as bases do sistema capitalista que é o

\footnotetext{
${ }^{8}$ Nesse sentido, a questão das mudanças climáticas é uma possibilidade de questionar com legitimidade científica (ou seja, com os argumentos de dentro do próprio sistema) os paradigmas do modo de vida ocidental e do discurso mesmo de desenvolvimento.
} 
causador, nessa perspectiva, da crise climática, aproximamo-nos da problemática colocada pelos autores que tratam da geopolítica do conhecimento: se, para estes, não há como repensar a realidade sem repensar as formas pelas quais se pensa a realidade, para os movimentos sociais que defendem a justiça climática é impossível encontrar soluções para a crise climática sem reformular os termos a partir dos quais a questão é formulada, a saber: sem considerar que a crise climática é apenas um desdobramento de uma crise sistêmica mais ampla, resultante de uma formação social, econômica, política e cultural.

Assim, a questão por trás do debate e das ações paliativas para evitar o agravamento das mudanças climáticas é a diferença entre percepções de mundo que estão na base da relação entre humanidade e natureza. Visões antagônicas sobre o que é natureza pautam relações e interesses diferentes:

\begin{abstract}
Enquanto as comunidades indígenas e rurais tendem a perceber a natureza como um elemento importante com significados simbólicos e como o sustento de seus meios de subsistência, as imagens orientadas ao extrativismo conectam a natureza com os interesses de explorar seus recursos e gerar renda. Essas últimas imagens são especialmente defendidas pelos governos nacionais e as grandes empresas. Curiosamente, embora os governos andinos hoje também utilizem as imagens indígenas simbólicas da Pachamama e do Bem Viver em seus discursos, seu significado foi reformulado com objetivos políticos nacionais. Para esses governos, essas imagens se transformaram em parte das políticas, nas quais a natureza representa uma oportunidade única de apoio a um projeto de desenvolvimento nacional. (Castro, Hogenboom e Baud, 2015:25)
\end{abstract}

Identificamos como geopolítica do conhecimento a divisão do mundo entre países formuladores de teoria e países receptores. Em termos de modelos epistemológicos, Mignolo (2002) assinala que fomos, na América Latina, formados desde a colonização a pensar o mundo a partir da visão moderna européia-ocidental. Isto porque este processo tem suas raízes na expansão capitalista, que não leva consigo apenas um modo de produção, mas um modo de pensar - assim como o cristianismo não leva consigo uma crença ou religiosidade, mas também uma forma de ver o mundo e pensá-lo. Um dos grandes sinais do trunfo do conhecimento ocidental sobre os outros conhecimentos é a legitimidade da escrita enquanto tecnologia necessária para a reflexão científica e filosófica, deslegitimando outras formas de transmissão do conhecimento (Castro-Gómez et al., 2002:13). Como desdobramento da soberania do conhecimento ocidental, tem-se que sua força reside no fato de que este conhecimento é reconhecido não por fornecer uma visão de mundo, e sim por fornecer a realidade; uma 
realidade que tem como centro enunciador a Europa.

O campo de mudanças climáticas é legitimado por algumas práticas (estabelecimento de fóruns, mecanismos e acordos internacionais), saberes (climatologia, engenharia florestal) e sujeitos (instituições e grupos) que compartilham de uma visão sobre o que são as mudanças climáticas (mais do que sobre como proceder em relação ao tema), e compartilham, assim, de uma formação discursiva que constitui esse campo. A legitimidade dessa formação discursiva sob respaldo científico, inquestionável, é produzida a partir de determinados lugares e constituindo-se como regime de verdade que acaba determinando as formas de continuidade ou nãocontinuidade da vida humana - a este processo de organização da reprodução da vida humana em interação orientada com o meio ambiente Ulloa (2011) chama de ecogovernabilidade. Ao mesmo tempo que se produz esse regime de verdade sobre as mudanças climáticas, noções distintas sobre "meio ambiente" são invisibilizadas. Nesse sentido, a ecogovernamentalidade, associada à geopolítica do conhecimento, pode ser entendida como uma nova forma de colonialidade do poder, enquanto discurso legítimo que afirma a necessidade de uma intervenção global para prevenir riscos. O que se disputa no campo das mudanças climáticas não são as premissas que o constituem, legitimadas pela visão dos científicos, mas a maneira como essa intervenção será feita.

\footnotetext{
La relación entre localización geográfica y producción de conocimiento es evidente a través de la generación de tecnologias eficientes, información de riesgos especializada, vulnerabilidad y adaptación, ubicadas en países específicos, lo que los convierte en exportadores e implementadores de nuevas mercancias asociadas al cambio climático (...) y, asimismo, permite la expansión de procesos académicos y prácticas disciplinarias en torno al cambio climático. Es decir, se construye uma distribución geoepistemológica, en donde otros conocimientos quedan invisibilizados. En este sentido, el cambio climático nos summerge nuevamente en una colonialidade del poder (saber). El efecto es la consolidación de una visión surgida del conocimiento experto de las universidades de países desarrollados, donde se estabelece desde el qué hacer y el como resolver los problemas del cambio climático hasta caules son las opciones políticas. Así se reconfiguran las geopolíticas del conocimiento centradas en la producción y legitimidad de los expertos. (Ulloa 2011, p. 489)
}

Buscar soluções para a crise climática a partir do sistema que a criou não traz soluções reais, apenas paliativos ou agravantes para a crise já instaurada - essa é precisamente a crítica das organizações que se reúnem para discutir a justiça climática, argumentando que os mecanismos flexíveis permitem aos países desenvolvidos seguir no mesmo modo de produção sem medidas efetivas para reduzir significativamente suas 
emissões de gases de efeito estufa, delegando isto a outros países ${ }^{9}$. Como formular e buscar soluções para a situação climática atual e futura, se a maioria dos governos, organizações e instituições estão inseridas no sistema-mundo hegemônico capitalista? É aí que os povos indígenas entram, como uma das vozes capazes de fazer frente ao modelo vigente em diversas ordens - da prática à filosófica e espiritual. Essa é, pelo menos, a maneira como alguns autores (Ulloa 2011, Quijano 2011) definem a presença indígena neste debate.

O pensamento fronteiriço é o que parte do exterior do "mundo moderno" ou do império, ou seja, é a história contada pelos que estão de fora e não dentro. É esse pensamento que, nas palavras de Mignolo, pode apontar para as lacunas que o pensamento hegemônico não é capaz de enxergar, abrindo "a possibilidade para a diversidade como projeto epistémico, ético, político e econômico" (Mignolo 2002, p. 235).

1.5 Expectativas e imaginários construídos sobre os povos indígenas

Powless (2012) destaca que os discursos (declarações e posicionamentos) indígenas na UNFCCC são marcadamente distintos dos de outras partes participantes, caracterizados por dois aspectos: primeiro, por reivindicarem reduções de emissão de gases de efeito estufa mais ambiciosas que as discutidas nas negociações; segundo, por tocarem na dimensão espiritual e não-material da relação entre seres humanos e natureza (segundo ele, "uma crítica e desacordo em relação aos processos atuais e históricos de controle e commodificação do planeta") considera que esses discursos podem ser lidos como uma "forma moderna de conhecimento indígena". A crítica feita pelos povos indígenas às Partes vai além das "falsas soluções" propostas por empresas e governos; são discursos apontam para o cerne comum de atividades diversas (das produções agrícola e industrial às fontes de energia) que afetam tanto os povos indígenas quanto o clima, como desdobramentos de processos coloniais e do sistema econômico vigente.

\footnotetext{
${ }^{9}$ Cabe destacar que isso é parcialmente verdadeiro, pois apenas uma porcentagem das metas de redução de emissões de gases de efeito estufa podem ser deduzidas dos mecanismos flexíveis. Ainda assim, entende-se que a crítica é direcionada à manutenção das estruturas de produção, distribuição e consumo, e não às ações que tenham em vista apenas a redução da emissão de gases de efeito estufa.
} 
Entretanto, povos indígenas se inserem e ganham força no campo de debate sobre mudanças climáticas a partir de alianças e pontos em comum de seus discursos com o de outros (como todos os sujeitos fazem nesse campo): de um lado, as manifestações indígenas por autonomia, direito aos territórios e preservação dos serviços ecossistêmicos destes pelo manejo tradicional se aproximam das reivindicações de grupos ambientalistas; de outro, grupos anticapitalistas apostam no ideal cosmológico alternativo de povos indígenas para defender que a ruptura sistêmica com o modelo capitalista é a única solução para a crise ambiental; e até mesmo chefes de Estado de países da América do Sul evocam as populações originárias para questionar as relações internacionais entre Estados e a tomada de ações - é o caso do posicionamento dos governos boliviano, equatoriano e venezuelano às vésperas da Conferência do Clima de 2015, que evocavam a defesa da Mãe Terra ("Pachamama") para cobrar responsabilidade dos países desenvolvidos.

O movimento indígena tem base proeminentemente identitária, ou seja, seu potencial reside na etnicidade. Isso é um fator de força e, ao mesmo tempo, de fraqueza para a mobilização transnacional indígena (Brysk 1996): de força, pelo forte apelo que o imaginário indígena traz em termos midiáticos, especialmente na relação entre povos indígenas "do Sul” e agentes (organizações da sociedade civil e outras instituições de apoio a povos indígenas) "do Norte” - segundo Brysk, há uma visão distinta por parte dos que convivem com povos indígenas em seus países e dos que vivem longe, que reside precisamente no imaginário sobre povos indígenas: entre os que convivem, "no Sul”, povos indígenas são associados ao imaginário do não-civilizado e ao atraso (acirrando conflitos e disputas); para os "do Norte", que não compartilham terras com tais povos, estes são tidos como exóticos e fascinantes (associados ao ‘bom selvagem') - o que agrega mais facilmente apoio internacional. Nesse sentido, marcas identitárias tornam-se fundamentais para acessar o imaginário sobre o que são povos indígenas, recurso utilizado por estes. Atualmente, a identidade e os discursos sobre identidade são as "armas" utilizadas pelos povos indígenas na defesa de seus direitos na guerra contemporânea do mundo globalizado. Mas quais são os limites de convergência entre a imagem de povos indígenas colocadas pelo movimento indígena e o imaginário acionado em seus interlocutores ao fazê-lo? Quais pontos de encontro entre o que diz o movimento indígena e o que seus interlocutores entendem que eles dizem são alinhados e quais são desvios de entendimento ou tradução? 
O movimento indígena alcança proporções mundiais basicamente pela mobilização de redes não-governamentais transnacionais (Brysk 1996, p. 39), especialmente pelo discurso ambientalista. A emergência crescente da agenda ambientalista a partir dos anos 1970 (Relatório Brundtland, clube de Roma) agrega, especialmente a partir da década de 1980, os povos indígenas, tomados como guardiões da floresta (ainda que esse casamento de agendas tenha gerado atritos). Povos indígenas projetam a imagem de si próprios enquanto protetores da natureza ("Salvaremos a vida de todos do planeta ao proteger a natureza, não só a nossa" é a declaração de um Paiakan na capa de revista norteamericana em 1991, citado por Brysk, 1996). Essa imagem do indígena enquanto "nativo ecológico" (nos termos de Ulloa 2004) é uma interpretação ocidentalizada da relação entre povos indígenas e meio ambiente, vista como uma relação harmônica; esta interpretação, entretanto, não compreende exatamente os termos em que essa relação diferente se dá, pois partimos das nossas categorias para estabelecer essa relação - categorias que, de inicio, separam natureza e meio ambiente dos seres humanos, diferente de cosmologias indígenas que colocam outras continuidades e diferenciações entre seres vivos e espíritos ${ }^{10}$. No entanto, ainda que essa tradução de termos seja falha, a imagem de guardião da natureza ou nativo ecológico é usada tanto por povos indígenas quanto por seus apoiadores não indígenas, mobilizada em discursos políticos de maneira consciente ou inconsciente - pois é a partir dessa imagem que povos indígenas alcançam posição de destaque no campo ambiental.

Recentemente, autores como Quijano (2011), Acosta (2011) e Farrah \& Vasapollo (2011) observam nos discursos e propostas indígenas - especificamente a do Vivir Bien - destacadas vozes que apontam para rumos que devem ser seriamente considerados como alternativas políticas e de padrões de vida em um contexto de certo esgotamento de outras alternativas (como os regimes socialistas), ao que se pode atribuir uma característica contra-hegemônica. O Vivir Bien ou Buen Vivir é descrito como uma ruptura ao desenvolvimento unilinear e capitalista, como um possível "novo paradigma civilizatório" (Farrah \& Vasapollo, 2011, p.19) que consiste em uma convivência harmônica com a natureza, embasada por valores culturais dos povos indígenas que rompem com a ordenação política e econômica da vida cotidiana voltada

\footnotetext{
10 Inúmeros trabalhos etnográficos poderiam evidenciar como diferentes etnias percebem essas continuidades e diferenciações entre os seres que compõem o mundo. Duas referências são os trabalhos de Basso (1996) e Cayón (2010).
} 
para o crescimento e o desenvolvimento capitalistas.

A emergência do indigenismo também tem a ver com o movimento de um "público" maior em busca de alternativas à sociedade moderna (Niezen 2003). Especialmente na América Latina, Quijano e Stavenhagen (1985) enxergam a força propulsora das populações indígenas latino-americanas para impulsionar processos de real ruptura com os paradigmas europeus - tanto no campo do conhecimento, quanto da prática. Se Stavenhagen (op.cit.) destaca a importância do questionamento das premissas do "desenvolvimento" e do etnodesenvolvimento enquanto contraponto que rompe com a premissa de evolução unilinear partindo de valores de grupos étnicos e não eurocêntricos, Quijano (2011) coloca como práticas de descolonialidade do poder a reorganização dos modos de produção e distribuição associadas à igualdade social heterogênea, ou seja, que não seja homogeneizante, respeitando a diversidade étnica. Assim, longe de qualquer homogeneidade, o que une os povos indígenas para estes autores é a oposição frente o sistema, justamente a negação de seus rótulos e classificações. Hoje, a percepção sobre o potencial revolucionário destes grupos minoritários mudou bastante, como afirma Quijano:

\footnotetext{
América Latina y la población "indígena" ocupan, pues, un lugar basal, fundante, en la constitución y en la historia de la Colonialidad del Poder. De allí, su actual lugar y papel en la subversión epistémica / teórica / histórica / estética / ética / política de este patrón de poder en crisis, implicada en las propuestas de Des / Colonialidad Global del Poder y del Bien Vivir como una existencia social alternativa. (2011, p. 859)
}

Ao analisar a forma de atuação de parte do movimento indígena - tomando a COICA como exemplo e como articularam uma proposta específica -, é possível observar com mais clareza os pontos de convergência do discurso indígena e de nãoindígenas, tornando-se evidente os esforços de tradução de ambos os lados. Nesse sentido, para além de afirmar que a atuação do movimento indígena tenha um viés ambientalista, contra hegemônico ou revolucionário, trata-se de compreender que as formas de incidência política e reivindicações indígenas remetem a outras visões de mundo - e estas outras visões são associadas a visões de mundo de grupos nãoindígenas e projetadas de maneira conjunta. 
1.6 Participação de povos indígenas no debate sobre mudanças climáticas

1.6.1 As Conferências das Partes: espaços que possibilitam a participação indígena?

Durante as COP, são realizadas paralelamente reuniões de representantes do Estado, grupos de trabalho e corpos técnicos convencionadas pela UNFCCC, a saber:

- "Meeting of the Parties" (CMP, sigla em inglês para Reunião das Partes), que são as reuniões entre os países que assinaram o Protocolo de Kyoto para discutir os progressos de implementação do Protocolo e avanços. Essa reunião acontece durante as $\mathrm{COP}$, sendo que na COP20 ocorreu a décima reunião CMP (marcando os dez anos que o Protocolo entrou em vigor em 2005).

- "Subsidiary Body for Implementation" (SBI, sigla em inglês para Órgão Subsidiário de Implementação), voltado para a revisão do cumprimento de compromissos de redução de emissões dos países.

- "Subsidiary Body for Scientific and Technical Analysis" (SBSTA, sigla em inglês para Órgão Subsidiário para Conselho Científico e Técnico), voltado para a elaboração de recomendações de ações e políticas a serem implementadas pelas Partes a partir da avaliação dos relatórios do IPCC $^{11}$.

- "Ad-hoc working group on the Durban Platform for Enhanced Action" (ADP, sigla em inglês para Grupo de Trabalho sobre a Plataforma de Durban) é um grupo formado na COP17 (2011), responsável pela elaboração de metas e produção de textos de acordos ou protocolocas que serão negociados nas $\mathrm{COP}$, com o objetivo de manter o aquecimento global no patamar de aumento da temperatura até $2^{\circ} \mathrm{C}$. Na COP20, a principal expectativa recaiu sobre o ADP, que deveria produzir um esboço de texto para o Acordo de Paris, firmado na COP21. As reuniões do ADP também ocorrem durante as COP.

Ainda, a sociedade civil organizada pode promover eventos chamados "side-events" e conferências de imprensa, que ocorrem dentro do espaço oficial. Assim, o espaço oficial é dividido em pavilhões destinados a abrigar cada tipo de evento: plenárias; side-events; conferências de imprensa; reuniões e negociações (CMP, SBSTA, SBI e ADP).

A participação da sociedade civil nas COP depende de registro que deve ser feito previamente. A UNFCCC permite a organizações da sociedade civil o registro sob o

\footnotetext{
${ }^{11}$ SBI e SBSTA são dois “corpos técnicos” permanentes estabelecidos pela UNFCCC.
} 
status de "Observador". Porém um indivíduo pode solicitar em seu país fazer parte da delegação nacional, cabendo a cada país definir critérios para a aceitação de indivíduos como parte de suas delegações nacionais; na COP20, por exemplo, o Brasil aceitou diversos segmentos da sociedade civil como parte de sua delegação oficial, incluindo grupos de jovens, povos indígenas, membros de ONGs e pesquisadores, como eu. Há uma diferença importante entre o tipo de registro, pois, sendo parte da delegação oficial de um país, recebe-se o registro como "Parte" e não "Observador": os Observadores podem acompanhar apenas as plenárias, side-events e conferências de imprensa dentro do espaço oficial; já as Partes podem acompanhar também algumas reuniões dos corpos técnicos e grupos, mas não as negociações (restritas apenas para os representantes do governo nas Partes). Assim, alguns indígenas participam das COP como parte de delegações oficiais, ou como Observadores ligados a ONGs e não exclusivamente necessitam registrar-se como membros de uma organização indígena (razão pela qual avaliar as organizações indígenas registradas na UNFCCC são um indicativo das organizações indígenas que participam das COP, mas não atestam a totalidade de organizações e representantes indígenas ali presentes - o Anexo I apresenta uma lista das organizações indígenas registradas na UNFCCC).

A programação das COPs é intensa, com dezenas de conferencias de imprensa diárias (acontecem duas de meia em meia hora) e side-events (existem aproximadamente sete salas destinadas a side-events, que ocorrem simultaneamente e têm duração de aproximadamente duas horas); plenárias e reuniões temáticas dos grupos (SBSTA, SBI, ADP), além das negociações entre as Partes (que ocorrem na segunda semana). Dada a impossibilidade de acompanhar todas as atividades relacionadas a um tema - acompanhar, por exemplo, as discussões sobre REDD+ em todos esses espaços é difícil -, é necessário um mapeamento criterioso de atividades. Considerando a quantidade de reuniões e as restrições de acesso e de fala dos Observadores em cada espaço, existe quase uma cisão no espaço oficial do evento: os representantes oficiais das Partes concentram-se nas negociações, reuniões fechadas e plenárias; e a sociedade civil concentra-se nos side-events, conferências de imprensa e plenárias (a depender do tema e da possibilidade de intervenção, participam de outros espaços e de plenárias específicas). As organizações da sociedade civil que acompanhei na COP20 (indígenas e ambientalistas) acabam participando de eventos organizados entre si (side-events e eventos fora do espaço oficial, onde é possível encontrar 
parceiros), de reuniões extra-oficiais (articuladas com um ou alguns dias de antecedência para algum tema específico) e de manifestações externas (como a Marcha do Clima, que acontece anualmente). Assim, as COP são espaços que possibilitam uma ainda restrita participação indígena, na medida em que sua possibilidade de incidência (possibilidade de fala) no espaço oficial é circunscrita; é por esse motivo que organizações indígenas como a COICA reivindicam a participação indígena como parte do grupo de experts e cientistas que compõem grupos como SBSTA e SBI.

1.6.2 Participação de organizações indígenas nas negociações internacionais do clima (COP)

Representantes indígenas participam pela primeira vez de uma COP em 1998 (COP4) e no ano seguinte é realizado o primeiro Forum Internacional Indígena sobre Mudanças Climáticas (International Indigenous Forum on Climate Change) junto à COP5. A segunda reunião desse Forum, em 2000, elabora um documento com as considerações das organizações indígenas presentes (sendo a COICA uma delas) sobre as mudanças climáticas e a UNFCCC (Declaration of Indigenous Peoples on Climate Change, International Indigenous Forum on Climate Change 2000), marcando a consolidação do engajamento indígena na discussão sobre o tema. Em 2001 é reconhecida a participação credenciada de povos indígenas na mesma categoria que a sociedade civil organizada, com o status de "Observador", o que possibilitou alguns espaços de fala (Powless 2012).

O Fórum Internacional Indígena sobre Mudanças Climáticas se consolidou ao longo dos anos como Caucus Indígena (ou sob o nome oficial de International Indigenous Peoples' Forum on Climate Change - IIPFCC) e institucionalizou-se como espaço de articulação das organizações indígenas durante as COP para a chegada de posicionamentos e estratégias de ação (lobby, manifestações, e participação em determinados eventos dentro e fora do espaço oficial da COP durante o período da reunião). As reuniões do Caucus Indígena acontecem diariamente pela manhã dentro do espaço oficial da COP, sendo reuniões reconhecidas pela UNFCCC e com espaço reservado para esta finalidade (as salas onde ocorrem mais tarde os side-events). Ainda, outros espaços institucionalizados pela ONU, como o Fórum Permanente sobre 
Assuntos Indígenas, são importantes espaços para a consolidação do discurso indígena sobre mudanças climáticas.

Progressivamente, os povos indígenas vão adquirindo algum espaço e reconhecimento no âmbito da UNFCCC. A partir de 2006 começam a ser promovidos side-events dedicados à questões indígenas. As organizações indígenas demandaram um grupo de trabalho específico para eles no âmbito da UNFCCC e reconhecido pela Convenção com o status de corpo técnico, para garantir-lhes um assento em reuniões privadas e propostas de alteração nos documentos oficiais da UNFCCC. Enquanto essa reivindicação não é atendida, o IIPFCC organizou grupos de trabalho temáticos para acompanhar as pautas das reuniões do SBI, SBSTA, ADP e em temas como Adaptação, REDD+, Construção de capacidades técnicas e Transferência de Tecnologias.

Powless (2012) descreve da seguinte maneira a participação das organizações indígenas nas COP:

\begin{abstract}
... the Indigenous caucus holds meetings prior to the official negotiation to share information and further develop its positions and strategy. Within the negotiations, the IICM [International Indigenous Climate Movement ${ }^{12}$ ] relies on making interventions in the official meetings and especially in plenary sessions. They organize press conferences and side events, which are attempts to reach out to broader audiences. They meet privately with states and host events or functions off-site. Lastly, and more so than perhaps any other constituency except youth, they organize or join others in direct actions or media stunts (Abhainn et al., 2007, pp. 133-4). These can be interpreted as acts of protest and appropriation of what is normally a state-dominated and defined space, especially when the actions arise spontaneously or when permission is not sought. (p. 417)
\end{abstract}

Esta é precisamente a maneira como observei a participação da COICA na COP20, a partir das definições do Caucus, mas também em torno de agendas regionais mais específicas, como a apresentação da proposta de RIA, tanto em side-events e conferências de imprensa, quanto em reuniões privadas com representantes de governo $^{13}$. Além disso, na COP20 a COICA organizou conferências de imprensa para cada organização base apresentar o contexto regional/nacional de ameaças aos direitos

\footnotetext{
${ }^{12}$ Powless aponta para a formação de um Movimento Internacional Indígena voltado para a questão das mudanças climáticas, porém essa articulação resume-se à reunião das organizações indígenas no âmbito do IIPFCC).

${ }^{13}$ Os acontecimentos fora do espaço oficial - reuniões e eventos que fortalecem redes e trocas de informação entre sujeitos variados; protestos e marchas da sociedade civil organizada são sempre organizados pelos movimentos sociais e geralmente contam com a participação das organizações indígenas.
} 
indígenas. Algumas das organizações mais presentes nas COP são Indigenous Peoples' International Centre for Policy Research and Education - Tebtebba e Asia Indigenous Peoples Pact - AIPP (Filipinas); COICA; Assembly of First Nations -AFN e Inuit Circumpolar Council - ICC $^{14}$ (América do Norte); estas são organizações que submetem suas propostas à UNFCCC para registro oficial, organizam side-events e participam ativamente do Caucus (apesar de, atualmente, o Caucus ser presidido por uma representante de organização de mulheres indígenas da República do Chade África). A Tebtebba e a COICA são as organizações indígenas mais ativas nos debates sobre REDD+, considerando que são originárias de regiões de florestas tropicais.

\footnotetext{
${ }^{14}$ A organização Inuit (Inuit Circumpolar Council) apresentou uma petição na Comissão Inter-americana de Direitos Humanos denunciando os EUA como violadores de direitos humanos e culturais devido à sua irresponsabilidade e omissão na tomada de ação para frear as mudanças climáticas. Foi o primeiro posicionamento a relacionar mudanças climáticas a direitos humanos - e aos direitos de povos indígenas.
} 


\section{Capítulo 2: A COICA e sua trajetória de atuação política internacional}

\subsection{Movimento indígena em escala mundial}

\subsection{1 "Indígena" enquanto categoria}

Pela impossibilidade de encontrar uma categoria que dê conta da multiplicidade de características culturais dos povos chamados indígenas e porque o aspecto primordial que os une enquanto "coletivo" é precisamente a oposição a uma sociedade ocidental dominante (intrinsecamente heterogênea), o contraste em relação a esta última é o traço que caracterizará outras culturas e povos como indígenas. Segundo Bonfil Batalla (1972), esta "atitude generalizante" se dá pelo fato de que uma categoria colonialista, formulada pelos próprios colonizadores, leva em conta apenas a distinção entre o "eu" e o outro, em que o "eu" é o colonizador, e o outro, todos os que não o são: o que importa nesta categorização é distinguir o colonizador do colonizado.

\footnotetext{
Esa gran diversidad interna queda anulada desde el momento mismo en que se inicia el proceso de conquista: las poblaciones prehispánicas ván a ver enmascarada su especificidad histórica y se van a convertir, dentro del nuevo orden colonial, en un ser plural v uniforme: el indio / los indios. (Bonfil Batalla 1972, p. 111)
}

A categoria "índio" ou "indígena" não leva em conta as características dos grupos étnicos em si, sendo um conceito supraétnico que se refere à relação entre os grupos étnicos e os colonizadores, com necessária referência às práticas coloniais e às relações engendradas por estas. Ao discutir os conceitos de índio e de etnia, Bonfil Batalla (idem) reforça o processo colonial que engendrou a categoria índio como pólo de uma relação dialética com o colonizador, de tal maneira que esta categoria "índio" é compreendida como resultado de um fenômeno histórico cuja existência e sentido estão diretamente relacionados à manutenção da lógica colonial. O autor reafirma que o conceito de "índio" é concebido no contexto colonial, no qual era preciso denominar, de maneira homogênea, os povos a serem "conquistados" na América:

Confío en que haya quedado suficientemente claro que la categoria de indio o indígena es un producto necesario del sistema colonial en América. Es, evidentemente, una categoría supraétnica que abarca indiscriminadamente a una serie de contingentes de diversa filiación 
histórica cuya única referencia común es la de estar destinados a ocupar, dentro del orden colonial, la posición subordinada que corresponde al colonizado. El problema consistiria en definir si la persistencia de la categoria social indio corresponde efectivamente a la persistencia de una situación colonial, o si debe entenderse como un remanente que ya no está sustentado por el orden social -colonial- que le dio origen. (1972, p. 119)

De maneira similar, Niezen (2003) aponta para a construção de uma identidade indígena compartilhada por grupos de diferentes partes do mundo que se configura pelas condições adversas que lhes foram impostas (ao mesmo tempo em que mantém entre si peculiaridades regionais), por compartilharem a situação de marginalidade e distinção perante as sociedades envolventes. Assim, o que os povos indígenas do mundo têm em comum são padrões de vida emergentes a partir da relação com lógicas de conquista e colonização dada pelo contato com outros grupos sociais. Para Niezen, os que se denominam "povos indígenas" compartilham hoje de similaridades significativas em suas experiências coloniais e pós-coloniais, como perda de terra e de meios de subsistência, quebra de tratos e imposição de políticas assimilacionistas tidas como destrutivas em termos psicológicos e sociais. Sob este aspecto, Niezen aproxima-se da noção de que a "unidade" do conceito indígena reside na relação de oposição de um grupo minoritário étnico frente a um estado dominante (nesse sentido, converge com a noção proposta por Bonfil Batalla):

... collective self-identification is the source of the indigenous identity and the definition of indigenous peoples (...). Indigenous peoples are not only those who say they are indigenous, but also those who are accepted by a global network of nations and communities with similar claims and sources of recognition. (2003, p.22)

Assumindo o que propõem Niezen e Bonfil Batalla, entende-se aqui a pertinência da utilização do termo "indígena" no singular tanto por compreender grupos diversos reunidos sob uma categoria em oposição a outro grupo (o de colonizadores históricos) quanto pela sua identificação enquanto voz unificada que se levanta contra o que Niezen chama de "forças destrutivas da modernidade" (2003, p.2). Partindo do conceito de "essência" como uma história comum, compartilhada por grupos étnicos com raízes e memórias que os unem, para os povos indígenas colocamse dois lados do essencialismo: de um lado, o discurso do essencialismo pode ser usado como justificativa para a suposta inferioridade racial e étnica, muito evidente em discursos de senso comum e de setores de governos latino-americanos; por outro, o 
essencialismo também pode ser colocado pelos povos indígenas como auto-afirmação e forma de resistência.

2.1.2 Movimento indígena: no singular ou no plural?

Assumo aqui a proposição de Baniwa (2007) para tratar do movimento indígena no singular:

\begin{abstract}
Movimento indígena, segundo uma definição mais comum entre as lideranças indígenas, é o conjunto de estratégias e ações que as comunidades, organizações e povos indígenas desenvolvem de forma minimamente articulada em defesa de seus direitos e interesses coletivos. O líder indígena Daniel Mundurucu costuma dizer que no lugar de movimento indígena deverse-ia dizer ÍNDIOS EM MOVIMENTO. Ele tem certa razão, pois não existe no Brasil um movimento indígena. Existem muitos movimentos indígenas, uma vez que cada aldeia, cada povo ou cada território indígena estabelece e desenvolve seu movimento de luta em defesa de seus direitos. Mas as lideranças indígenas brasileiras, de forma sábia, gostam de afirmar que existe sim um movimento indígena, aquele que busca articular todas as diferentes ações e estratégias dos povos indígenas, na perspectiva de uma luta articulada em níveis locais, regionais, nacional e internacional em torno dos direitos e interesses comuns, frente a outros segmentos e interesses nacionais e regionais. (p. 128)
\end{abstract}

Baniwa (idem) ainda afirma que a negação do movimento indígena unificado (no Brasil, mas considero que isto se aplica para o movimento indígena mais amplo, transnacional) representa uma perda política significativa, assinalando que trata-se de estratégia eficaz dos não-indígenas promover a falta de unidade entre os povos indígenas para enfraquecer sua resistência.

Warren e Jackson (2002) falam sobre como os movimentos indígenas são muito menos coesos e uniformes do que seus apoiadores sugerem, por motivos diversos e características étnico-culturais que diferenciam os povos e comunidades que compõem o movimento indígena. Entretanto, a definição do movimento indígena enquanto tal reside precisamente no aspecto étnico/cultural que caracteriza o movimento (ainda que de maneira genérica - indígena), sendo a cultura um aspecto central para a proeminência do movimento indígena no cenário internacional.

Para dialogar com o imaginário de povos indígenas e de maneira a fortalecer suas vozes politicamente, o movimento indígena assume a identidade genérica de 
"indígena", maneira pela qual suas pautas assumem legitimidade perante o Estado e outros sujeitos políticos, ao apresentar as noções de identidade e cultura. Essa é, muitas vezes, a maneira encontrada para a garantia de aspectos essenciais para a sobrevivência, como o direito à terra e a seus recursos naturais.

\begin{abstract}
It is not uncommon to see indigenous groups forging their sense of identity around the organizing idea of a coherent and bounded common culture. In many countries, indigenous communities must legally establish their legitimacy through the rhetoric of cultural continuity in order to gain official recognition, protection, and access to resources including their lands. (Warren e Jackson 2002, p. 2)
\end{abstract}

A crítica sobre a legitimidade cultural ou étnica de um povo ou do movimento indígena é vazia, no sentido em que a "essencialização" da cultura é mais uma estratégia política do que uma realidade - isso não significa dizer que não existam particularidades culturais e étnicas que distinguem os povos indígenas, e sim, que a maneira como as categorias de "cultura" e "etnia" são discutidas remetem a uma essencialização construída para as esferas de discussão política. A própria definição de povos indígenas enquanto povos e não populações ou outro conceito vem da possibilidade que esse léxico pode abrir para os povos indígenas no direito internacional; trata-se, portanto, de uma escolha política do movimento em seu autodefinir enquanto povo indígena em um esforço de tradução que cabe para as reivindicações do movimento.

Para Warren e Jackson (2002), o que interessa à antropologia não é avaliar qual é a fidedignidade do movimento indígena em relação a sua cultura, e sim, analisar como esse conceito é construído e praticado enquanto retórica política - e enquanto catalisador da construção de identidades. Uma das retóricas do movimento indígena organizado para articular as formas atuais de vida e cultura dos povos indígenas às formas tradicionais é a necessária revitalização cultural pela qual passam frente a sociedades cada vez mais urbanizadas e globalizadas, levando em conta que o passado que remete tanto à ancestralidade quanto à exploração colonial pela qual os povos indígenas passaram permanece sendo central e compartilhada. Assim, as autoras destacam que o grande desafio para a antropologia dedicada a analisar as organizações indígenas é o estudo das escolhas que os povos em contextos distintos fizeram em termos da formação de suas identidades (revitalizadas). 
Além da identificação dos elementos comuns aos povos indígenas - e de seus discursos - reconhecidos e engendrados nestes espaços de encontro, Bello (2004) apresenta alguns aspectos fundamentais à construção do que se pode chamar de "movimento indígena": a associação de reivindicações políticas ao caráter identitário, na medida em que se assume a identidade étnica como a auto-afirmação de grupos perante outros; a construção do diálogo a partir dos termos dados pelos interlocutoresalvo, especialmente o Estado; a apropriação de discursos e estratégias em voga por parte das organizações indígenas, de maneira a fortalecer suas organizações e luta.

Apesar da variedade de formas de engajamento político dos povos indígenas, a mais efetiva e proeminente é o ativismo indígena por direitos - "The Indian rights movement, then, does not include all forms of political participation by Indians but rather is confined to groups working for principled change in the status and conditions of Indians as a distinct cultural group." (Brysk 1996, p. 42). A atuação da COICA enquadra-se nesse tipo de atuação, em prol do reconhecimento dos povos indígenas de maneira ampla, mais do que uma organização voltada para a transformação da realidade indígena diretamente na esfera local.

\subsubsection{Articulação transnacional do movimento indígena}

De acordo com Niezen (2003), o movimento indígena começa a se articular a nível mundial a partir da percepção de três aspectos: primeiro, de que é pouco eficaz ou inútil recorrer aos fóruns nacionais para tratar de algumas questões; segundo, pelas possibilidades de articulação e comunicação em rede dadas a partir das décadas de 1960/1970; e terceiro, pela noção de que os povos indígenas não são subjugados a uma autoridade nacional, mas devem relacionar-se com outras nações, que eventualmente possam auxiliar/apoiar suas reivindicações. Os fóruns internacionais em que representantes e lideranças de grupo se reúnem e compartilham experiências foram os espaços que possibilitaram a identificação de grupos nas situações mais diversas a encontrarem similaridades entre si, sendo o direito à auto-determinação e território centrais para sintetizar uma demanda conjunta dos povos indígenas.

Silva (2015) aponta para um aspecto comum das mobilizações indígenas na América Latina, a saber, seu caráter anticolonista. Entretanto, Silva apresenta como em 
regiões diferentes do continente, as mobilizações indígenas apresentaram especificidades apesar de compartilharem desse aspecto comum. Nesse sentido, reconheço a validade das proposições de Niezen (2003) a respeito da importância das circunstâncias compartilhadas pelo povos indígenas como aspecto que possibilita a articulação indígena transnacional de maneira unificada (cf. descrito anteriormente sobre a utilização do termo movimento indígena no singular); entretanto, é preciso reconhecer que, apesar disso, as organizações indígenas de partes diversas do mundo reunidas em fóruns internacionais apresentam trajetórias de mobilização e organização específicas, e que seu ponto de partida para a construção de pautas e estratégias de ação não é a articulação feita nestes fóruns internacionais, e sim a mobilização regional de seus locais de origem.

Além dos problemas comuns que povos indígenas de diversas partes do mundo têm de enfrentar, intensificados pela ação de agentes transnacionais, o movimento indígena é altamente transnacionalizado também pela forte relação entre indígenas e organizações intergovernamentais e não-governamentais transnacionais. A transnacionalização de movimentos sociais é uma estratégia adotada por diversos movimentos sociais, cada vez mais comum na atual organização do sistema-mundo ${ }^{15}$. Segundo Brysk (1996), se, por um lado, a pauta dos direitos indígenas parece pouco associada a um caso de transnacionalização de movimento social considerando a marginalização dos povos indígenas em relação aos Estados nacionais, é precisamente essa fraqueza dentro dos limites nacionais que leva ao fortalecimento das alianças transnacionais entre outras partes diversas do mundo e com outros tipos de agentes. Alguns aspectos podem estar associados a esse fortalecimento transnacional: 1) as barreiras do idioma, de acesso a recursos e participação em espaços que são um obstáculo já enfrentado por povos indígenas na esfera nacional, não sendo um obstáculo exatamente "novo" a ser superado quando se trata da esfera internacional; 2) a não-identificação de povos indígenas com a população nacional dominante permite maior possibilidade de aliança com agentes internacionais; e/ou 3) as críticas

${ }^{15}$ Sobre a desqualificação que nacionalistas/governos fazem do apoio internacional ao movimento indígena, Brysk (1996) comenta a hipocrisia disto lembrando que o próprio Estado e seus grupos dominantes na América Latina contaram com apoio e recursos internacionais para se fortalecer. - "In the case of Indian movements, local Latino elites historically dominated Indian populations through monopoly of access to markets, transport, state services, and other channels of contact with 'outsiders'." (p. 42) 
(posicionamentos antagônicos em relação) ao Estado nacional trazem um apelo mais facilmente identificado pela comunidade internacional.

De acordo com a perspectiva dos teóricos dos Novos Movimentos Sociais (cf. Brysk 1996), o ativismo parte da mobilização e das identidades mais do que dos recursos materiais; assim, essa perspectiva aponta que o êxito de um movimento transnacional está relacionado à capacidade do movimento de construir uma imagem e uma identidade. É assim que a etnicidade confere ao movimento indígena um recurso capaz de fortalecer suas redes transnacionais.

Brysk (1996) aponta para o alcance e a potencialidade do ativismo transnacional para o movimento indígena, afirmando que as redes transnacionais conferem aos movimentos sociais uma força política capaz de transformação social destaca, por exemplo, como a articulação de organizações em torno da pauta indígena ganhou força e repercussão a ponto de "reformar organizações internacionais" como a ONU (com a declaração do Ano dos Povos Indígenas em 1993, a criação do Grupo de Trabalho de Povos Indígenas e de um Fundo para Povos Indígenas do Banco Interamericano de Desenvolvimento) e como a mobilização transnacional é capaz de incidir sobre as políticas nacionais (como no caso da demarcação da Terra Indígena Yanomami). Se, por um lado, as redes transnacionais fortaleceram o movimento indígena e foram, em alguns casos, fundamentais para o atendimento de reivindicações indígenas, é preciso levar-se em conta também o fato de que as organizações internacionais que compõem essa rede têm agendas e prioridades que, geralmente, definem quais reivindicações devem ser apoiadas, por vezes direcionando os esforços do próprio movimento indígena, uma vez que as pautas que ganham mais força nesse contexto são as que convergem com os interesses dos agentes internacionais que compõem essa rede transnacional de apoio ao movimento indígena.

O apoio internacional é não só um fator que fortalece o movimento indígena, como também fomenta a própria formação de organizações indígenas. Para algumas agências financiadoras (como OXFAM), a formação de organizações é uma diretriz dos programas de apoio.

\footnotetext{
“... it is striking that many movements initially developed form local to international before a corresponding national level of organization was established (...). This pattern extends further: a number of domestic Indian rights groups were established
} 
with significant international support (Willetts, 1982). Transnational religious groups (such as the Salesian in Ecuador and the Brazilian Bishops' Conference) have played a proeminent role in establishing a number of Indian rights organizations (Stavenhagen, 1988: 149). Both the indigenous advocacy group Cultural Survival and OXFAM America have explicitly identified 'instituion building' as a program goal (...)”. (Brysk 1996 p. 44)

Um aspecto que fortalece a criação e manutenção de redes transnacionais no movimento indígena é a maior facilidade, por incrível que pareça, em estabelecer comunicação e obter apoio entre indígenas de um país da América do Sul e nãoindígenas de organizações do Norte do que entre os grupos indígenas da América do Sul entre si, dada a dificuldade de acesso, isolamento geográfico e escassez financeira para possibilitar a configuração de uma rede amazônica por si só. Segundo ambientalista do Norte entrevistado por Brysk (1996), é física e politicamente mais fácil para um indígena amazônico encontrar-se e comunicar-se com um ambientalista de fora como ele do que com ambientalistas de seu próprio país - que dirá dos indígenas de seu próprio país, que não contam com uma estrutura de ONG por trás de si. A autora ilustra em uma frase o rápido salto que muitos grupos indígenas fizeram das alianças locais - ou, por vezes, do próprio contato inicial com não-indígenas -, às alianças transnacionais em um curto espaço de tempo, mostrando o ritmo em que as coisas se configuram em um mundo globalizado: "In a way that illuminates the emerging shape of transnational politics, South American Indians went from oral history to sound bites in one generation" (idem, p. 48).

2.2 A COICA: constituição, consolidação e atuação indígena ambientalista

2.2.1 A formação de organizações indígenas amazônicas

O aumento do interesse econômico e político na região amazônica trouxe muitas mudanças para a região especialmente entre as décadas de 1960 e 1990, com o incremento de atividades decorrentes de intervenções estatais e não-estatais: mineração, extrativismo, agropecuária, construção de rodovias, hidrelétricas e programas de reordenação territorial (colonização e assentamento) (Smith 1996; Albert 1995; Becker 2005). Como resultado destas atividades, aumenta a proximidade entre os povos indígenas e não-indígenas das sociedades nacionais a partir do maior acesso 
a áreas antes mais isoladas e como resultado das ondas migratórias de mão-de-obra para trabalhar nos empreendimentos (fazendas, obras, extrativismo).

Muitas vezes, essas intervenções e contato geraram impactos prejudiciais aos povos indígenas da região (perda de território, doenças, violência, imposição religiosa), os quais passaram a se organizar para fazer frente a essas mudanças e seus desdobramentos. Assim, as organizações indígenas amazônicas foram formadas com o objetivo de fazer frente às ações predatórias que ameaçam os territórios e suas vidas, tendo, portanto, como cerne, pautas como a defesa do território, autonomia e identidade étnica. Pode-se dizer que as mais variadas situações de ameaça a que os povos indígenas amazônicos estiveram historicamente expostos os fez organizar-se politicamente de alguma maneira, em instâncias pelas quais a interlocução com agentes estatais e não-estatais de intervenção pudessem ser feitas. As organizações de povos indígenas amazônicos prescindem, de maneira similar, da reivindicação pelas terras espoliadas, da piora das condições de vida (perante outros paradigmas de saúde, trabalho, educação e religião) e da identificação social dos grupos indígenas em oposição aos 'outros', que faz com que grupos indígenas comecem a organizar reuniões para discutir estas questões cotidianas que os assolam enquanto povos.

O contexto em que se formam as organizações base da COICA - Asociación Interétnica de Desarrollo de la Selva Peruana (AIDESEP, Peru), Central de Pueblos y Comunidades Indígenas del Oriente Boliviano (CIDOB, Bolívia), Confederación de Nacionalidades Indígenas de la Amazonia Ecuatoriana (CONFENIAE, Equador), Organización Nacional Indígena de Colombia (ONIC, Colômbia) e União das Nações Indígenas (UNI, Brasil) ${ }^{16}$-, entre meados da década de 1970 e início da década de 1980, ilustra a similaridade de situações que levam povos indígenas diversos a formarem esse tipo de associações. Todas apresentam alguns aspectos em comum: são constituídas por articulações entre diversas etnias; têm como central a pauta territorial (pelo reconhecimento e contra invasões e atividades econômicas depredatórias); o apoio de entidades da sociedade civil para a realização de reuniões e são motivadas pela necessidade de uma organização que possa reivindicar legitimamente as questões indígenas (a partir da identificação de problemas comuns como a saúde, a educação e a desvalorização da cultura indígena) junto aos Estados nacionais. No caso do Peru,

\footnotetext{
${ }^{16}$ Para uma descrição mais detalhada sobre o processo de formação de AIDESEP e CIDOB, ver Duval (2014); para uma descrição do contexto de formação da UNI, ver Bicalho (2010).
} 
Equador e Brasil é ainda destacada a atuação de religiosos no processo de formação das organizações locais ou regionais.

\subsubsection{A participação dos povos indígenas amazônicos em fóruns internacionais}

Apesar da configuração de organizações indígenas nos países amazônicos concentrar-se entre as décadas de 1960 e 1970, o debate político sobre a "questão indígena" e indigenista é institucionalizado internacionalmente bem antes a partir da década de 1930. Na América Latina, agências nacionais dedicadas à questão indígena são criadas entre o final da década de 1930 e início da década de 1950. Entretanto, os termos do indigenismo institucionalizado até então (de caráter majoritiamente integracionista) são criticados e revistos, abrindo espaço para noções como etnodesenvolvimento e pluralismo cultural (Verdum 2006), e para a participação de lideranças indígenas nos debates para definição dos rumos do chamado indigenismo.

Especificamente na região amazônica, os povos indígenas conquistam visibilidade internacional devido a ação de antropólogos (em trabalhos individuais ou por meio de organizações) a partir da década de 1960, no contexto de intensificação das atividades econômicas da região descritos nas seções anteriores (Smith 1996, p. 104). A Conferencia de Barbados em 1971 representa um marco da atuação dos antropólogos engajados com a questão indígena na América do Sul, da qual resultou a Declaração de Barbados, que destaca a dominação colonial (agora interna) à qual os povos indígenas das Américas seguem submetidos, descrevendo as responsabilidades e impactos das ações do Estado, das missões religiosas e dos antropólogos diante deste contexto, e a libertação dos povos indígenas como resultado de sua ação própria. Segundo Smith (1996), essa Declaração ganhou ressonância entre acadêmicos, religiosos e órgãos de governo das Américas e da Europa, contribuindo para a visibilidade e internacionalização da questão indígena ${ }^{17}$.

Entre o final da década de 1960 e meados da década de 1970, formaram-se muitas organizações não-indígenas "do Norte” de apoio aos povos indígenas, como

\footnotetext{
${ }^{17}$ Em 1977 foi realizada uma segunda conferência em Barbados, que contou com a participação dos mesmos antropólogos que atenderam à primeira, e com lideranças indígenas. A repercussão internacional desta segunda Conferencia foi menor que a primeira, apesar da participação dos indígenas. (Smith, 1996)
} 
International Work Group for Indigenous Affairs (IWGIA), com sede em Copenhagen; Survival International, com sede em Londres; Cultural Survival, com sede em Cambridge (EUA) ${ }^{18}$. Com enfoque na defesa dos direitos humanos e na proteção territorial e da diversidade cultural, estas organizações projetaram mundialmente a temática indígena especialmente amazônica, promovendo informação e debates a respeito da questão indígena em círculos acadêmicos e de políticas em prol dos direitos humanos a nível nacional e internacional. Foram, ainda, ONGs "do Norte" que apoiaram financeiramente a formação de organizações indígenas amazônicas (inclusive a AIDESEP e a CIDOB).

A partir do final da década de 1970 lideranças indígenas amazônicas ganham projeção no cenário internacional por sua participação em eventos, em conferências como a Segunda Conferencia de Barbados (1977), a Conferência Mundial das Nações Unidas sobre Racismo e Discriminação Racial (1978), Conferência do World Council of Indigenous Peoples (WCIP) ${ }^{19}$ (1975 e 1980) e Conferência sobre Controle de Recursos Nativos e Problemática de Corporações Multinacionais (1982), entre outros. Segundo Smith (1996), estes eventos possibilitaram a lideranças indígenas amazônicas conhecer diferentes aspectos relacionados a ameaças a seus povos e, ao mesmo tempo, "ampliar suas perspectivas através de reuniões com seus interlocutores de outros países, escutando diferentes análises de sua situações e descobrindo possibilidades de cooperação internacional para suas lutas" (p. 106).

Articulações entre atores diversos - indígenas e não-indígenas - foram feitas na década de 1970 tendo em vista a melhoria das condições de vida e direitos dos povos indígenas da América Latina - seja pela articulação de grupos indígenas (como aconteceu no Equador), seja pela atuação de ativistas e antropólogos (como no Peru e Colômbia), ou pela incidência política de indígenas junto ao governo nacional (Brasil). A década de 1980 foi marcada pela formação de organizações (mencionadas acima) e fóruns de não-indígenas que serviram como uma rede de apoio e espaços para articulação importantes para a configuração do movimento indígena em escala

\footnotetext{
${ }^{18}$ Para uma descrição sobre as mudanças de enfoque que guiaram o apoio dado pela cooperação internacional a povos indígenas no Brasil (que, porém, parecem ser adotadas de maneira similar em outros países), ver Barroso-Hoffman (2005)

${ }^{19}$ Organização internacional com sede no Canadá instituída em 1975 (e que encerrou suas atividades em 1996) voltada para a defesa dos povos indígenas de todo o mundo, adquirindo o status de observador na ONU.
} 
internacional, como a Organização Internacional do Trabalho (OIT) e o Conselho Mundial de Igrejas passaram a tratar de questões indígenas. Em 1982 a ONU institui o Grupo de Trabalho sobre Povos Indígenas em sua Comissão de Direitos Humanos, como forma de responder à pressão internacional de povos indígenas e aliados em relação aos direitos destes povos. As reuniões anuais deste Grupo de Trabalho possibilitaram a lideranças indígenas de partes diversas do mundo conformar um espaço de troca que, como apontado anteriormente, são os espaços que possibilitam a existência e configuração de um movimento indígena mundialmente articulado.

2.2.3 A formação de organizações indígenas amazônicas transnacionais: o CISA e a COICA

A primeira reunião com o intuito de reunir os povos indígenas sulamericanos aconteceu no Peru em 1980, promovida por organizações como Movimento Indio Peruano, WCIP e IWGIA. Na ocasião, foi criado o Consejo Indio de Sudamerica (CISA), que passou a atuar na esfera internacional, já integrando desde o início (1982) a Comissão de Direitos Humanos da ONU, no âmbito do seu Conselho Social e Econômico.

A comienzos de 1980, un grupo de profesores universitários mestizos del Movimiento Indio Peruano, colaboraron con algunos bien intencionados activistas y académicos de los países escandinavos y con el recentemente establecido Consejo Mundial de Pueblos Indios (WCIP), patrocinaron una conferencia indígena internacional en las afueras de Cuzco. Muchos de los que participaron tenían dudosas credenciales como líderes, e incluso como índios; los reportes publicados anunciaron que hubo más seguidores de índios que índios (anônimo 1980). De cualquier manera, en médio de acusaciones de fraude y mala administración, el Consejo Indigena de Sur America (CISA) fue establecido como una voz para los pueblos indígenas en la arena internacional. Para recibir ayuda de las agencias financeiras internacionales, CISA necesitaba algunas organizaciones de base para legitimizarse pero CISA no podia aún reclamar legitimamente la representación de las comunidades de base del movimiento de federaciones étnicas en el Amazonas. (Smith 1996, p. 93)

Entre 1980 e 1983, no entanto, diversas denúncias e críticas são feitas ao CISA por organizações indígenas amazônicas menores, que concluem que esta organização 
não refletia as posições e preocupações dos povos indígenas amazônicos; dentre as críticas feitas ao CISA estão denúncias de corrupção, de táticas agressivas e posicionamentos em fóruns internacionais não discutidos prévia e abertamente com organizações locais.

A COICA foi fundada em 1984 na cidade de Lima, Peru, no primeiro Congresso de Organizações Indígenas da Bacia Amazônica, que reuniu cinco organizações regionais indígenas: AIDESEP, CIDOB, CONFENIAE, ONIC e UNI. A AIDESEP organizou a reunião, razão pela qual esta ocorreu em Lima. O principal ponto da agenda era o Grupo de Trabalho de Povos Indígenas da ONU, uma avaliação dos temas tratados no Grupo de Ttrabalho e da elaboração de uma estratégia para participar das reuniões anuais deste. A formação da COICA acontece após alguns encontros entre organizações indígenas amazônicas em resposta à assinatura do Tratado de Cooperação Amazônica, pela percepção dos impactos que esse tratado traria aos povos indígenas da região, e a partir da insatisfação das organizações e lideranças indígenas ali reunidas a respeito da atuação do CISA. O intuito de constituir a COICA era criar uma organização realmente representativa dos povos indígenas amazônicos e unificar suas vozes em defesa dos direitos dos povos indígenas para atuar em esfera internacional, reunindo as estratégias e pautas comuns dos povos.

A COICA representaria uma aliança de organizações indígenas para tratar especificamente de questões que afetavam a mais de um país amazônico, ou seja, para tratar de temas transnacionais, em resposta às iniciativas igualmente transnacionais de intervenção territorial por parte de Estados e empresas. Por isso e para isso, a COICA seria uma organização que participaria e executaria ações internacionais a partir do consenso de suas organizações membro, cuja autonomia e poder de decisão sobre as ações da COICA não deveriam sempre prevalecer em relação à diretoria da COICA. $\mathrm{Na}$ ocasião, definiu-se que as linhas de ação ou decisões importantes, bem como a diretoria da COICA, seriam definidas em assembleias gerais a realizarem-se a cada quatro anos. 
2.2.4 Os primeiros anos da COICA e a conformação de sua estrutura e modus operandi

Smith $(1996)^{20}$ relata que os primeiros cinco anos de existência da COICA foram marcados pelo baixo financiamento internacional, num contexto de "desconfiança" a respeito de uma organização indígena transnacional e de grande dispêndio de tempo e energia por parte do primeiro presidente da COICA, Evaristo Nugkuag (da AIDESEP), em dedicar-se a consolidar a COICA.

COICA enfrento la enorme tarea de crear para sí misma un espacio político a nível internacional. Cada año una nueva delegación de líderes, representantes de COICA, participo en las reuniones del Grupo de Trabajo de la ONU, abriendo el caminho a otras representaciones de pueblos indígenas, aprendiendo las estratégias de la política internacional, y descubriendo a quién creer, en médio del creciente numero de aliados y burocratas involucrados en la problemática indígenas. La expansión de la influencia de COICA en el contexto del Grupo de Trabajo de la ONU se debió, tanto al crecimiento de su visión como al talento político de sus líderes. (p. 109)

A COICA participou da revisão do Convenio 169 da OIT e marcou presença em diversos espaços internacionais, fazendo contatos com grupos de apoio a povos indígenas e movimentos sociais diversos, bem como partidos verdes e outros. Estes contatos foram essenciais para a formação de uma base política e financeira (europeia) para a COICA. Muito da constituição dessa rede de apoio para a COICA e do reconhecimento de sua influencia direta e indireta em decisões e textos internacionais teve a ver com a atuação do então presidente Evaristo Nugkuag, que recebe em 1986 um prêmio - o Right Livelihood ${ }^{21}$ - que o garante visibilidade internacional e o

\footnotetext{
${ }^{20}$ Dedico especial ênfase a este autor pois ele reconstitui a história de formação da COICA desde a formação de federações étnicas peruanas até a Assembleia Geral da COICA de 1992 com muito detalhe. Além de seus trabalhos serem ser referência para autores como Stefano Varese e Alyson Brysk, Smith é um dos poucos autores que presenciou e relatou estes primeiros anos da COICA.

${ }^{21}$ Smith (como outros autores, segundo ele) critica aqui a premiação individual a presidentes de organizações indígenas, afirmando que este tipo de premio deveria ser oferecido à organização, e não a um indivíduo que responde por ela: é mais importante, segundo Smith, reconhecer a importância da ação e da organização coletiva dos povos indígenas do que centrar o reconhecimento em um indivíduo, algo que é tão característico da cultura e realidade ocidental, mas que tem uma natureza diversa de um movimento coletivamente declarado. Ademais, segundo ele, o fato de o prêmio consistir numa soma
} 
aumento da cobertura de imprensa dos Estados Unidos e Europa, bem como maior espaço em círculos oficiais e inclusive a atenção do então presidente do Banco Mundial, Barber Conable (o que posteriormente se reflete na abertura de espaço de diálogo entre Banco Mundial e COICA ${ }^{22}$ ).

A segunda assembleia da COICA é realizada em 1988 na sede da CIDOB, na Bolívia. Segundo Smith (1996), esta assembleia foi marcada por campanhas e "políticas eleitoreiras e com discursos de conteúdo escasso" (p. 110) que se assemelhavam à política partidária de qualquer país do mundo, incluindo o financiamento internacional, indicando o crescente interesse de lideranças e grupos em assumir a presidência da organização. Nessa assembleia, Evaristo é reeleito presidente da COICA e a sede desta mantém-se em Lima, rompendo assim dois pactos fundamentais da COICA: a rotatividade da presidência e da sede.

Entre 1992 e 1993, outras quatro organizações indígenas somaram-se à COICA - Consejo Nacional Indio de Venezuela (CONIVE), Organisatie van Inheemsen in Suriname (OIS), Amerindian Peoples Association of Guyana (APA), Fédération des Organisations Autochtones de Guyane (FOAG). Ainda, entre 1994 e 1995 algumas organizações - UNI e ONIC - deixaram a COICA por razões diversas, dando lugar a outras organizações indígenas destes países: COIAB e a Organización de Pueblos Indígenas de la Amazonia Colombiana (OPIAC), que tornou-se membro da COICA no lugar da ONIC. Apesar da participação de novas organizações na COICA na assembleia de 1992, foram estabelecidas algumas mudanças: 1) a redefinição da estrutura de coordenação da COICA, antes representada pelo presidente, que é substituída por um coordenador geral, um vice-coordenador e quatro coordenadores de áreas (Território, Desenvolvimento autônomo, Direitos Humanos e Recursos Naturais/Meio Ambiente); 2) uma junta diretiva composta por um representante de cada uma das nove organizações membro da COICA, responsáveis pela elaboração de políticas de longo prazo e acompanhar as defendidas pelos coordenadores eleitos; 3) a mudança da sede da COICA de Lima para o escritório permanente em Quito, Equador (onde permanece até hoje); e 4) a realização de auditorias periódicas.

considerável de dinheiro representa um problema adicional ao movimento indígena - ou à COICA -, na medida em que, para o autor, "contribui para o crescimento da corrupção entre seus líderes".

${ }^{22}$ A política do Banco Mundial relacionada a povos indígenas é definida na Diretiva Operativa 4.20 publicada em 1991, e substituída em 2005 pela Política Operacional (OP) e Procedimentos do Banco (BP) 4.10 . 
A história da COICA é atrelada à cooperação internacional desde os seus primeiros anos: apoiadores como Agência de Cooperação Técnica Alemã (GIZ), Ford e OXFAM viabilizaram financeiramente a instituição e manutenção da COICA, acompanhados da preocupação internacional e de organizações não-indígenas com a floresta amazônica e com as populações que ali vivem. É no período entre 1988 e 1992 que a COICA começa a receber os louros pelos esforços de seus anos iniciais - os contatos feitos até então e a participação ativa em eventos públicos e articulação com outras organizações resultam em crescentes oportunidades para a COICA junto à imprensa, agências financeiras e convites para conferencias, reuniões e outros eventos com custos cobertos (Smith, 1996).

Se, por um lado, no fim da década de 1980 e início da década de 1990 a COICA passa a ser reconhecida internacionalmente e aumentar o número de apoiadores e interlocutores mais diversos, ganhando espaço nos círculos internacionais ambientalistas e de defesa dos direitos humanos, por outro lado, o aumento de sua participação internacional em diversas áreas resulta em um distanciamento crescente de suas organizações base, sendo a comunicação um dos principais problemas estruturais da COICA a partir desse momento e até hoje. Uma comunicação falha entre as organizações base da COICA, que deveria ser nada mais que uma entidade representativa das posições destas organizações (conforme o pacto firmado na constituição da COICA em 1984), resulta na dificuldade ou impossibilidade de chegar a consensos sobre temas não só que ameaçam os povos indígenas amazônicos de maneira imediata, como em relação aos temas que são ameaças indiretas ou futuras, aos quais uma organização de atuação internacional como a COICA tem muito mais possibilidade de interferir sobre do que as organizações regionais ou nacionais.

Smith (1996) relata o desafio com que uma organização indígena como a COICA se depara frente a, de um lado, pressões por posicionamentos relativamente rápidos por parte de interlocutores e agencias como o Banco Mundial e, de outro, pelo tempo necessário que a discussão e elaboração de posicionamento das organizações indígenas de base demanda; na maior parte das vezes, esses tempos são diferentes e deve-se optar por abster-se pela ausência de discussão com as bases ou tomar um posicionamento antecipado em relação à discussão com as bases, o que pode, em alguns casos, colocar a legitimidade da representação em questionamento. Ademais, a 
morosidade e complexidade das negociações internacionais dificulta a interlocução entre instâncias internacionais, a COICA e suas bases, considerando o longo prazo e baixa perceptividade no cotidiano das discussões feitas nesse âmbito - e, em última instância, do trabalho feito pela COICA. Nas palavras do ex-coordenador geral, Segundo Antonio Tisoy (2011),

\footnotetext{
Debemos tener en cuenta además que el sistema multilateral de Naciones Unidas tiende a ser complejo y a menudo pasan varios años antes de que se tomen medidas y adopten decisiones vinculantes (Convenios o resoluciones de las Partes) o no vinculantes (declaraciones y recomendaciones ), lo que implica que la (COICA) tuvo para sus propósitos de reivindicación de derechos, mantener uma constante presencia institucional en períodos de mediano y largo plazo, antes de ver avances en el reconocimiento de los mismos. Otro elemento es que el sistema de las Naciones Unidas produce con frecuencia desfases entre diferentes instancias del mismo, de manera que algunas acciones por lo general son a menudo descoordinadas entre sus agencias y frecuentemente contradictorias. Sin embargo, de manera novedosa la COICA en nueve años plantea la necesidad de la armonización entre las determinaciones de diferentes instancias de los sistemas multilaterales y, específicamente, frente a las Conferencias de las Partes (COP) del CDB y la Comisión de DD.HH. (p. 13)
}

Para além de qualquer dificuldade técnica ou financeira para melhorar a comunicação interna da COICA e, assim, manter o ideal de posicionamentos oficiais representativos elaborados a partir de consensos, Smith (1996) aponta dois aspectos que contribuem para os problemas de comunicação da COICA: de um lado, aponta para a centralização de expertise e informação em uma cúpula (o presidente e outros a ele próximos, por exemplo) associada a um traço cultural de algumas etnias amazônicas, em que o conhecimento é tido como um recurso pessoal ou familiar de poder, que não é transmitido de maneira horizontal; ou seja, uma espécie de "norma cultural" que prescreve o não-compartilhamento generalizado de conhecimento para fora de um determinado grupo. De outro lado, Smith aponta para uma tendência das organizações indígenas (não apenas da COICA, mas de outras que acompanhou, como a dos Amuesha) em adotar um estilo político similar a de seus interlocutores nacionais/regionais não-indígenas. Smith (1996) tece críticas à maneira como a COICA vem atuando desde 1988, cada vez mais voltada para o exterior e distanciada de seus membros e organizações locais, mirando o aumento de financiamento externo 
não acompanhado pela capacidade de controle fiscal e social por parte das organizações base; aponta para o risco de que, em uma organização de ampla escala como a COICA, estes representantes estarem quase imunes ao controle social comunitário, pelo formato de rede da organização, com sedes fisicamente distantes das comunidades. Estes problemas culminaram com a divisão da COICA em 2005, sob sérias acusações de organizações indígenas sobre corrupção e falta de transparência por parte da coordenação geral. À época, a coordenação geral foi assumida pela COIAB, representada por Sebastião Manchineri, e as principais críticas foram apresentadas pela organização indígena do equador, a CONFENIAE ${ }^{23}$.

As críticas sobre o distanciamento, a falta de diálogo e mesmo à legitimidade da COICA enquanto representante dos povos amazônicos seguem bastante atuais ${ }^{24}$. Ainda segundo Smith, os representantes eleitos em organizações indígenas como a COICA tendem a adotar um estilo político "criollo" e personalista que coloca interesses pessoais à frente dos das comunidades bem como a falta de responsabilidade de organizações indígenas em relação às comunidades que representa, no sentido em que os representados por uma federação/organização pouco sabem sobre o que seus representantes dizem ou fazem em nome deles. Crítica similar é feita por Segundo Antonio Tisoy (2011):

En la mayoría de los casos se adoptaron y aceptaron determinaciones contrarias a las propuestas de los pueblos indígenas. Los dirigentes se convirtieron en la última instancia de decisión, y adoptaron un esquema de representación formal más que reconocer el de autoridad tradicional que implicaba una mirada del mundo con identidad ni volvieron a consultarlos. (p. 34)

Considerando estas críticas, o grande desafio da COICA reside na maneira de fazer política que a organização define, que guarda o "dilema” entre o estilo político baseado em valores da cultura dominante versus a política baseada em valores locais sendo que este segundo ainda apresenta o desafio da definição de um local que abrange etnias e, portanto, culturas e valores diversos. Para Smith, é preciso que os representantes indígenas de organizações como a COICA voltem-se ao aprendizado de liderança dos anciãos (que manejam formas de fazer política locais diferentes das

\footnotetext{
${ }^{23}$ Para mais detalhes sobre a divisão da COICA em 2005, ver Servindi (2005).

${ }^{24}$ De acordo com comunicação pessoal feita por membros algumas organizações base da COICA em 2014 e 2015.
} 
estratégias eleitoreiras e "criollas") - o que considero bastante improvável considerando a diferença de questões que os caciques manejam em suas comunidades e um representante indígena nacional/transnacional tem que manejar. A liderança exercida pelos anciãos volta-se para a resolução de situações de ordem e escala distintas, se comparadas ao contexto em que lideranças indígenas que circulam internacionalmente estão inseridas ${ }^{25}$.

\subsubsection{COICA e as organizações ambientalistas}

As ONGs ambientalistas que se consolidam entre 1960 e 1970 (para uma descrição sobre a formação e crescimento de algumas das principais ONGs conservacionistas, ver Chapin 2004), especialmente nos Estados Unidos, tem um caráter conservacionista, considerando a tendência vigente à época de entender a natureza como algo a ser preservado sem qualquer interferência humana. Essa lógica conservacionista vai perdendo força a partir da década de 1990, mas ainda assim existe resistência em trabalhar com povos indígenas por motivos diversos, conforme descreve Chapin (2004):

La discusión de alianzas "naturales" entre conservacionistas y pueblos indígenas y la necesidad de trabajar estrechamente con comunidades locales, que se daba comúnmente hacía unos pocos años [década de 1980], ya es algo del pasado. Las principales ONG conservacionistas la reemplazaron por el tema de cambio de prioridades, con un nuevo enfoque hacia estrategias de conservación amplias y la importancia de la ciencia, y no las realidades sociales, para determinar sus agendas. A la par, se ha hablado en voz baja de cuán "difícil" pueden ser los pueblos indígenas y trabajar con ellos y, en lugares como Ecuador, Bolivia y la región de Chiapas de México, que algunos han escogido el camino de la agitación e incluso la violencia. Algunos sectores del movimiento conservacionista han advertido que los pueblos indígenas no son - contrario a lo que muchos de ellos han estado pregonado - aliados apropiados por que, al igual que la mayoría de las personas, éstos no son siquiera buenos conservacionistas, pues en ocasiones han preferido su próprio bienestar económico a la preservación de recursos naturales. (p. 4)

\footnotetext{
${ }^{25}$ Ramos (1998) descreve algumas das dificuldades encontradas por esse tipo de liderança.
} 
Com o apoio de organizações internacionais (como OXFAM, Cultural Survival e Survival International), a COICA pressiona as organizações ambientalistas a escutar a perspectiva dos povos indígenas sobre a conservação de áreas de floresta, especialmente considerando a discussão sobre áreas protegidas, com reflexos diretos sobre a definição de parques nacionais em locais coincidentes ou próximas a terras indígenas. No contexto de crescentes intervenções na região amazônica descritos anteriormente e que fundamentam a própria formação da COICA, esta faz em 1989 um chamado aos ativistas ambientalistas com a proposta de formar uma aliança em defesa da Amazônia, em um documento chamado "Two Agendas on Amazon Development", no qual apresentam diretrizes para um modelo de desenvolvimento da Amazônia que leve em consideração os povos indígenas e seus direitos. Nesse documento, chamam tanto governos e empresas que desenvolvem projetos na Amazônia que respeitem os direitos e territórios indígenas e a construção de diálogos para a realização de projetos, quanto a cooperação internacional e ambientalistas, destacando seu papel para a preservação da biodiversidade e seu conhecimento milenar desta. Em uma seção destinada especificamente aos ambientalistas, a COICA declara a importância dos povos indígenas para a manutenção da biodiversidade amazônica, sua casa, e demonstra preocupação em relação à atuação de ambientalistas que intervêm em prol da conservação das florestas sem considerar os povos indígenas que ali vivem, nem suas condições de vida ou interesses, concluindo com o chamado para o apoio aos povos amazônicos e a construção de uma aliança entre ambientalistas e povos indígenas pela conservação da Amazônia:

\section{TO THE COMMUNITY OF CONCERNED ENVIRONMENTALISTS}

We, the Indigenous Peoples, have been an integral part of the Amazonian Biosphere for millennia. We use and care for the resources of that biosphere with respect, because it is our home, and because we know that our survival and that of our future generations depend on it. Our accumulated knowledge about the ecology of our forest home, our models for living within the Amazonian Biosphere, our reverence and respect for the tropical forest and its other inhabitants, both plant and animal, are the keys to guaranteeing the future of the Amazon Basin. A guarantee not only for our peoples, but also for all of humanity. (...)

We are keenly aware that you share with us a common perception of the dangers which face our homeland. While we may differ about the methods to 
be used, we do share a fundamental concern for encouraging the long-term conservation and the intelligent use of the Amazonian rain forest.

We are concerned that you have left us, the Indigenous Peoples, out of your vision of the Amazonian Biosphere. The focus of concern of the environmental community has typically been the preservation of the tropical forest and its plant and animal inhabitants. You have shown little interest in its human inhabitants who are also part of that biosphere. (...)

We are concerned that you have left us Indigenous Peoples and our organizations out of the political process which is determining the future of our homeland. While we appreciate your efforts on our behalf, we want to make it clear that we never delegated any power of representation to the environmentalist community nor to any individual or organization within that community.

$(\ldots)$

We want you, the environmental community, to recognize that the most effective defense of the Amazonian Biosphere is the recognition of our ownership rights over our territories and the promotion of our models for living within that biosphere.

We want you, the environmental community, to recognize that we Indigenous Peoples are an important and integral part of the Amazonian Biosphere.

We want you, the environmental community, to recognize and promote our rights as Indigenous Peoples as we have been defining those rights within the UN Working Group for Indigenous Peoples.

We want to represent ourselves and our interests directly in all negotiations concerning the future of our Amazonian homeland.

(..)

We propose that you work directly with our organizations on all your programs and campaigns which affect our homelands.

We propose reaching out to other Amazonian peoples such as the rubber tappers, the Brazil-nut gatherers, and others whose livelihood depends on the nondestructive extractive activities, many of whom are of indigenous origin.

We propose that you consider allying yourselves with us, the Indigenous Peoples of the Amazon, in defense of our Amazonian homeland.

(Two Agendas On Amazon Development, publicado pela Cultural Survival, disponível em: http://www.culturalsurvival.org/publications/culturalsurvival-quarterly/none/two-agendas-amazon-development )

Este documento é um marco pela discussão que causou sobre as possibilidades de aliança e de manejo de áreas protegidas, culminando com o "Primer Encuentro 
que reuniu povos indígenas do Peru, Brasil, Bolívia, Equador e Colômbia e organizações ambientalistas como World Wildlife Fund (WWF), Rainforest Alliance, Conservation International, Friends of the Earth e Greenpeace (entre outros). Dessa reunião sai a Declaração de Iquitos (Anexo II), que atesta a aliança entre povos indígenas e ambientalistas em prol da conservação da Amazônia. É o momento em que a COICA consolida seu discurso sobre povos indígenas e seu modo de vida como chave para a proteção da floresta amazônica, em resposta à ideia conservacionista de parques nacionais difundida especialmente nos Estados Unidos; um momento em que a noção de índio ecológico é afirmada no discurso da COICA, para se consolidar ao longo de sua trajetória e da de outros aliados, noção que logo encontra ressonância em diversos meios, da imprensa à academia. É a partir daí que grandes ONGs como WWF e The Nature Conservancy passaram a redirecionar suas agendas de maneira a incluir povos tradicionais e reconhecer, em documentos e declarações, a importância dos povos indígenas e de seus direitos ${ }^{26}$. Dessa maneira, a COICA passa a desenvolver projetos em conjunto com organizações ambientalistas, contando com estas para apoio financeiro que garante a manutenção da própria COICA - até hoje, ONGs como WWF, IPAM, Forest Trends, The Nature Conservancy e Environmental Defense Fund subsidiam de maneiras diversas a COICA, assim como agências internacionais, com destaque para o Banco Mundial e GIZ, que aportaram importantes recursos para a COICA nos anos 2000.

Todavia ainda existem muitas tensões entre organizações indígenas e ambientalistas, não solucionadas por estas iniciativas. Se há diretrizes explícitas de agências financiadoras para o apoio a comunidades locais, seguiram-se ainda até meados dos anos 2000 desafios para o trabalho conjunto entre ambientalistas e organizações indígenas: 1) pelo fato de muitas vezes as ONGs ambientalistas planejarem projetos que seriam implementados em territórios indígenas sem construção conjunta, "top-down", de um lado; 2) pela reiteração da dificuldade de trabalhar com povos indígenas sem "garantia" de que conceder-lhes seus direitos represente a conservação do meio ambiente, objetivo este máximo e não a melhoria das condições de vida de comunidades, de outro. Apesar de o documento da COICA mostrar um claro objetivo comum entre ambientalistas e indígenas - a preservação da

\footnotetext{
${ }^{26}$ Indicador dessa mudança é o documento produzido pela WWF em 1996, "Principles and Guidelines on Indigenous and Traditional Peoples and Protected Area: Joint Policy Statement", que reconhece explicitamente o papel e conhecimento dos povos indígenas sobre seus territórios.
} 
Amazônia -, sua ação conjunta mostra-se na realidade bastante difícil, quando muitas vezes os interesses reais e cotidianos dos povos indígenas no chão não parecem corresponder aos interesses dos ambientalistas, o que fica evidente na hora da concepção de projetos: existe o embate entre a "conservação verdadeira" e o "desenvolvimento comunitário", ou o estranhamento por parte de muitos aliados dos povos indígenas ao ouvir o que os povos indígenas querem: ferramentas, tratores ou computadores, coisas diversas do que se esperaria para "manter a natureza intacta" (tratarei dessa questão no próximo capítulo).

\subsubsection{Atuação da COICA na agenda ambientalista: a Convenção da Diversidade Biológica}

A ECO-92 foi um evento que fortaleceu as alianças internacionais da COICA, e no qual a participação desta contribuiu para a consolidação já em curso do trabalho da COICA junto a redes ambientalistas internacionais. A COICA passa a participar continuamente não apenas dos fóruns sobre povos indígenas e direitos humanos da ONU, como também das Conferencias sobre Meio Ambiente como a ECO-92, Biodiversidade e Clima (COP).

En suma la década del 90 del siglo XX sufrió una reingeniería "global” tanto política, económica, social y cultural. Por eso el papel de la dirigencia de los pueblos indígenas se nutrió conceptualmente de un trabajo fraterno de base en malocas, tambos y casas del saber tradicional, especialmente de los compañeros indígenas que acompañaron el proceso de discusiones y propuestas dentro del Convenio de la Diversidad Biológica CDB, artículo 8j y disposiciones conexas durante estos años, convencidos de que nuestra voz sería escuchada en los escenarios políticos y jurídicos nacionales e internacionales. Esta característica no solo contribuyó al proceso en el CDB sino influyó en avanzar y sustentar resoluciones de la Comisión de Derechos Humanos y el Grupo de trabajo sobre el proyecto de Declaración de los Derechos de los Pueblos Indígenas de la (ONU), con las que como resultados efectivos los pueblos indígenas tuvieron el establecimiento del Foro Permanente para las Cuestiones Indígenas de la ONU y la adopción de la Declaración de los Derechos de los Pueblos Indígenas del Mundo que apuntalan hasta hoy políticas públicas de derechos humanos. (Tisoy 2011, p. 2) 
Entre 1996 e 2001 há um esforço exitoso da COICA para a construção do reconhecimento do Fórum Indígena Internacional sobre Biodiversidade e na contribuição da COICA para a Convenção de Diversidade Biológica (CDB), culminando com a criação de um Grupo de Trabalho sobre conhecimentos tradicionais no âmbito desta. A COICA elabora uma série de documentos e publicações que tratam do tema biodiversidade e de discussões feitas sobre esse tema entre povos indígenas amazônicos ${ }^{27}$.

O envolvimento da COICA com a CDB parece similar ao seu posicionamento frente à REDD+ (que será melhor descrito no próximo capítulo): trata-se de um tema que envolve a discussão de direitos dos povos indígenas (no caso do $\mathrm{CDB}$, relacionado mais especificamente à propriedade intelectual, e no de REDD+, ao território) e que perpassa sua autonomia e possibilidades de desenvolvimento econômico.

\begin{abstract}
Por ello la (COICA) vio en el (CDB) un campo donde estaba en peligro la supervivencia de los pueblos mismos así que decidió avanzar conceptualmente en esa dirección, y ese es estructuralmente su aporte: construir una visión más amplia de la diversidad cultural y biológica. Para ello propuso mecanismos claves como la creación de espacios interculturales, de diálogo de saberes y de multiculturalidad, en medio de un proceso económico de globalización del mundo, conceptos que son relevantes en la actualidad. Así la participación de los pueblos indígenas amazónicos inicialmente se enfocó en la defensa de los elementos centrales de los derechos colectivos y en la construcción de una plataforma de representatividad y legitimidad frente a una Agenda Internacional, específicamente del (CDB). (Tisoy 2011, p. 40-41)
\end{abstract}

A crítica feita pela COICA e descrita por Tisoy (2011) em relação à CDB converge com as críticas à REDD+ também pela visão colonial do que é conservação de recursos naturais, que, em textos iniciais, coloca os povos indígenas e seus conhecimentos de maneira secundária e/ou utilitarista, reduzida à "conservação do meio ambiente" nos termos convencionados por

\footnotetext{
${ }^{27}$ Alguns destes documentos: "Entre lo proprio y lo ajeno: derechos de los pueblos indigenas y propiedad intelectual" (Torres 1997) e "Biodiversidad y Derechos de los pueblos indígenas: Manual de Capacitación de Base." (COICA 1998).
} 
não-indígenas: dito de outra maneira, e com as palavras de Tisoy, se trata de ver os povos indígenas como elementos ou ferramentas úteis à conservação, mas não como sujeitos. No fundo, a discussão da COICA em relação à REDD+ segue o mesmo caminho percorrido quando se elaborou a $\mathrm{CDB}$, e que tem relação com a discussão entre ambientalistas e organizações indígenas: disputar qual é a visão de conservação de meio ambiente vigente, que prescinde de conceitos a respeito do que é meio ambiente e conservação (além de outros conceitos relacionados a estes, como natureza, seres humanos e povos indígenas). Tanto no diálogo com ambientalistas quanto na discussão sobre biodiversidade e clima, as organizações indígenas reiteradamente colocam que tem uma visão própria sobre estes temas que são características de seu pensamento e que diverge do não-indígena; é da diferença entre essas visões de mundo (comumente definida como "visão de mundo" para os não-indígenas e “cosmovisão" para os indígenas) que discursos sobre a importância dos direitos coletivos, da autonomia, da valorização dos conhecimentos ancestrais e cultura são imbricados às "questões ambientais" (tal como são formuladas pelos nãoindígenas), numa tentativa de conciliar perspectivas e conceitos indígenas e não-indígenas.

Além disso, ambos os temas são complexos e exigem que a COICA faça uma articulação com suas bases para discutir o tema, articulação essa que envolve capacitação sobre o tema em si, o andamento das negociações internacionais a respeito e os impactos destas para a vida dos povos indígenas amazônicos. A COICA encontrou-se, nesse sentido, diante de um desafio similar em relação à $\mathrm{CDB}$ e a REDD+: a falta de informação de muitas comunidades e dirigentes que gera atritos em relação aos posicionamentos; a complexidade das terminologias utilizadas (biodiversidade e mudanças climáticas, por exemplo, são dois conceitos chave para estas discussões e que exigem a explicação de como os não-indígenas percebem e explicam o mundo); a falta de recursos humanos, financeiros e de tempo para promover uma discussão adequada com suas bases. Nos dois casos, isso não impediu - e não acredito que deva impedir - a COICA de tomar posicionamentos nas negociações, sob o risco de ser acusada de pouco representativa no melhor dos casos, e de ilegítima, no pior; entendo que o trabalho da COICA e de outras 
organizações indígenas que atuam na esfera internacional configura estratégia importante de constrangimento internacional que pode se traduzir em avanços para as organizações indígenas a nível nacional, além de lograr conquistas em termos de acordos no direito internacional que reforcem os direitos dos povos indígenas em escala mundial. 


\section{Capítulo 3: Apropriação, resistência e comunicação: RIA como instrumento político de diálogo}

Um relato de campo: sessão voltada para a discussão do mecanismo de REDD+ durante a COP20 (Lima, 2014):

Havia uma sessão dedicada a discutir o mecanismo de REDD+ entre as delegaçõos dos países. A sessão não ocorreu nos espaços de plenária (amplos e abertos a todos que podiam entrar no espaço oficial), e sim nas salas menores destinadas aos negociadores, com acesso restrito aos que possuíam credenciais da delegação dos países. Nesse sentido, o governo brasileiro merece reconhecimento, pois levou uma das maiores delegações oficiais para a COP20, com centenas de pessoas, incluindo sociedade civil e representantes indígenas o que nos permitiu acesso a esse tipo de sessão mais restrita. Ao entrar na sala, vi dois representantes da COICA da FOAG, Guiana Francesa (a França foi, de forma inédita, outro país que concedeu credenciais importantes para a sociedade civil organizada; razão pela qual, acredito, eram as lideranças indígenas da Guiana Francesa que tinham acesso a essa sessão que estavam ali representando a COICA). A sessão teve início com a inscrição de vários delegados de países. Dentre estas falas, delegados de países diversos - Estados Unidos, Suíça, Áustria, Camarões -, falaram em inglês sobre a importância de ouvir as comunidades locais, populações indígenas e tradicionais, a respeito do mecanismo de REDD+. Após reiterada afirmação vinda de várias delegações a respeito dessa importância, um dos delegados da COICA (Jocelyn Therese) se inscreve e fala. Sua primeira frase, que eu não entendi perfeitamente, pois foi enunciada em francês (segunda língua de Jocelyn, sendo a primeira língua o Kali-na), era algo como "estou aqui para apresentar a vocês a proposta de RIA da COICA". Nesse ponto Jocelyn foi interrompido pela mesa com a seguinte advertência (enunciada em inglês): "Lamento mas nesta sessão só são permitidas falas em inglês. Caso você não possa enunciar sua fala em inglês, poderá submetê-la à mesa por escrito". Jocelyn estava acompanhado por uma assessora peruana da COICA que, ao transmitir a mensagem a ele, saiu da sala, retornando quinze minutos depois com outro representante da COICA que falava inglês. 
Este, Juan Carlos, pelo que soube depois, estava no momento em reunião com delegados de alguns países, abandonando este espaço de articulação para se pronunciar na referida sessão dedicada a REDD+. Juan Carlos se inscreveu e fez a fala em inglês, que era, entretanto, bastante diferente do que parecia ser a fala de Jocelyn. Juan Carlos não falou da proposta de RIA, e sim da importância da participação dos povos indígenas na COP, e das dificuldades que estes enfrentam para conseguir isso - desde o alto custo para chegar e passar dias nas cidades do evento até a barreira do idioma. Sua fala foi pertinente não apenas pelo ocorrido com Jocelyn naquele momento, mas com tantos outros representantes indígenas neste e em outros espaços; e importante para evidenciar a contradição entre as falas dos delegados oficiais dos países a respeito da relevância dos posicionamentos indígenas a respeito de REDD+ que, quando se apresentam dentro dos espaços circunscritos oficialmente apesar das circunstâncias desfavoráveis à sua participação - como descrito por Juan Carlos -, são silenciados. O desfecho: apesar do esforço da COICA enquanto organização indígena em garantir a participação de representantes indígenas em um espaço bastante restritivo - esforço esse que consiste não apenas em garantir transporte, acomodação e alimentação (que em si só é bastante oneroso), mas também no trabalho de anos de formação para garantir uma fala que seja ouvida e respeitada neste espaço tanto em termos de idioma quanto de conceitos técnicos como REDD+ -, e da declarada disponibilidade e boa-vontade por parte dos países presentes em escutar as opiniões indígenas a respeito de REDD+, não se escutou, após o silenciamento da fala de Jocelyn, nem uma palavra indígena a respeito de REDD+ nesta sessão.

Assim como em outros momentos e espaços, o fato de indígenas não falarem a mesma língua que os governos nacionais resultou na sua exclusão em discussões, espaços de negociação ou mesmo consultas na ausência ou inexistência de tradutores ${ }^{28}$. Segundo Roberto Cardoso de Oliveira (2000), a ética discursiva é premissa para a efetivação de um verdadeiro diálogo entre lideranças indígenas e representantes oficiais do Estado, ou seja, para um diálogo interétnico democrático, simétrico e inteligível para todas as partes envolvidas. A inteligibilidade do diálogo depende do entendimento e

\footnotetext{
${ }^{28}$ Graham (2002) descreve a exclusão vivida pelos Waiãpi quando reunidos com a FUNAI para discutir a situação de suas terras sem a presença de um tradutor.
} 
aceitação entre os participantes sobre normas e regras; e, para que haja simetria no diálogo, é necessário estabelecer um espaço razoavelmente democrático, em que não haja a predominância de um interlocutor sobre outro - a existência de uma autoridade, (um interlocutor que exerça poder ou predominância de alguma forma em relação a outro) compromete a eticidade do diálogo.

Quando discutimos um diálogo interétnico ou intercultural ${ }^{29}$, ou seja, entre interlocutores que não compartilham dos mesmos pressupostos em relação a visões de mundo, normas e regras, é necessário um esforço ainda maior para alcançar a eticidade nos termos aqui referidos e o estabelecimento de um acordo entre as partes, considerando que não compartilham um horizonte semântico comum. De acordo com Cardoso de Oliveira (2000) e ilustrado pelo breve relato acima e em tantos outros espaços políticos interculturais que envolvem indígenas e não-indígenas, a predominância das regras de uma das partes tida como institucionalizada (a parte nãoindígena) compromete o caráter ético do diálogo intercultural, onde observa-se que os diálogos interculturais nos espaços institucionalizados como oficiais (comunidade nacional e internacional) necessariamente devem se enquadrar às regras do discurso hegemônico.

\subsection{Contexto em que RIA foi elaborado}

Retomando aqui o mecanismo de REDD+ apresentado no primeiro capítulo, é preciso distinguir a implementação de REDD+ por meio do estabelecimento de políticas estaduais ou nacionais de REDD+ de projetos de carbono florestal que podem ser desenvolvidos por agentes privados e não-governamentais no âmbito do mercado de carbono. O Acordo de Cancun (resultado da COP16, 2010) e o Marco de Varsóvia para REDD+ (resultado da COP19 em 2013) estabelecem o reconhecimento apenas das abordagens nacional e subnacional para implementação de REDD+, e não de projetos isso significa que a UNFCCC reconhece e regulamenta as iniciativas de REDD+ nessas escalas. Contudo, projetos de carbono florestal podem se desenvolver no âmbito do mercado de carbono, sendo implementados e certificados por outros agentes. Escapa aos

\footnotetext{
${ }^{29}$ Para o presente argumento, "diálogo interétnico" e "diálogo intercultural” têm sentidos idênticos.
} 
propósitos desta pesquisa discutir os pormenores do mercado de carbono; porém é importante destacar aqui que, antes das definições da UNFCCC em relação ao reconhecimento da escala de implementação de iniciativas de REDD+ (nacional e subnacional), assinaladas em 2010 e estabelecidas em 2013, houve um período de proliferação de iniciativas diversas de projetos de carbono florestal ou REDD+ ${ }^{30}$. Ademais, os projetos de carbono florestal foram considerados parte do que se considerou uma etapa "preparatória" para a implementação de REDD+ prévia à finalização das definições dos marcos de regulamentação de REDD+.

Assim, especialmente até 2012 (antes do estabelecimento do Marco de Varsóvia para REDD+) foram identificados diversos contratos para projetos de REDD+ em áreas de pequeno porte - a extensão equivalente a terras indígenas, por exemplo -, consideradas pequenas se comparadas à extensão de um Estado. A partir da definição do Mecanismo de Desenvolvimento Limpo e a subsequente constituição de um mercado de carbono, surgiram empresas para tratar desses projetos de REDD+ em áreas menores e “garantir" créditos de carbono a compradores ${ }^{31}$ referentes à manutenção dos estoques de carbono destas áreas.

Entretanto, muitos problemas foram identificados nesta abordagem de projetos de REDD+, desde a formulação dos contratos - com cláusulas que ferem os direitos indígenas - até o modo como os povos indígenas eram contatados por estas empresas, sem providência de qualquer acompanhamento legal para avaliação dos contratos, assinados muitas vezes sem o pleno conhecimento a respeito de suas cláusulas. No Brasil, por exemplo, entre 2010 e 2012 a Fundação Nacional do Índio (FUNAI) reportou conhecimento sobre mais de 30 etnias abordadas por empresas ou intermediários para tratar de projetos de carbono, sendo que nem todas as etnias abordadas assinaram contratos (vide Anexo III); os casos que ganharam mais destaque

\footnotetext{
${ }^{30}$ Após as decisões das COP na UNFCCC que não reconhecem projetos de REDD+, convencionou-se chamar os projetos existentes no mercado de carbono de projetos de carbono florestal; mas até o estabelecimento dessas decisões, muitos projetos eram (e ainda são, se considerado o mercado de carbono e não as diretrizes da UNFCCC como referência) denominados como projetos de REDD+.

31 Apesar das definições sobre REDD+ do Marco de Varsóvia terem finalmente definido os termos internacionais para a implementação nacional de REDD+, a questão sobre os pagamentos por resultado de REDD+ poderem ser utilizados como "créditos de carbono" para o cumprimento de metas de redução de emissões de países do Anexo I (chamado offsetting) permaneceu em aberto, pela falta de consenso entre as Partes a esse respeito. Assim, não fica nem vetada nem aprovada por enquanto a contabilização proveniente do apoio a REDD+ em países em desenvolvimento para o cumprimento das obrigações de mitigação dos países desenvolvidos; essa indefinição (ou melhor, a não proibição) possibilita o funcionamento do mercado de carbono.
} 
foram os contratos assinados pelos Cinta Larga e Munduruku, ambos com a empresa Celestial Green Ventures. O contrato firmado entre esta empresa e os Munduruku, por exemplo (vide Anexo IV), garante à empresa o direito total aos créditos de carbono da área e respectivos benefícios, submete à autorização da empresa para qualquer "intervenção na área do projeto" (inclusive para atividades agrícolas, comprometendo a autonomia do povo a seu território) e tem a duração de trinta anos (vinculando dessa maneira também a geração seguinte aos termos do contrato). Por causa de estas e outras irregularidades, contratos como este foram invalidados; entretanto, tal assédio aos povos indígenas e os abusos contidos neste tipo de abordagem e contrato geraram, com razão, grande desconfiança por parte de povos indígenas em relação a REDD+.

Esta é uma das razões pelas quais entidades do governo e da sociedade civil esforçaram-se em prover os povos indígenas de informações a respeito de REDD+ e contratos como este - a FUNAI realizou encontros, produziu textos e vídeos sobre a questão; a COICA divulgou em diversos materiais recomendações para o estabelecimento de acordos com empresas relacionados a REDD+ (COICA 2012). Mas, para além destes contratos abusivos que ameaçam os direitos indígenas, existe um impasse em relação a como contabilizar a contribuição destes projetos para a redução de gases de efeito estufa - e é esta a razão pela qual a UNFCCC não reconhece projetos de REDD+, apenas programas nacionais ou subnacionais.

A proposta da COICA de RIA converge com a visão dos programas de REDD+ estabelecida pela UNFCCC e não a abordagem de projetos (por isso, como veremos mais adiante, a proposta de RIA desenvolveu-se até concluir-se como aporte para a elaboração de políticas nacionais de REDD+), de forma a garantir a regulamentação e respeito aos direitos indígenas (previstos nas salvaguardas socioambientais) definidas pela UNFCCC ${ }^{32}$. Assim, a tendência que se observa de 2014 em diante é de que RIA possa influenciar as políticas públicas desenvolvidas pelos governos nacionais e estaduais de maneira a beneficiar as Terras Indígenas dentro destes limites.

Uma das críticas da COICA (e de outras organizações da sociedade civil) ao mecanismo de REDD, antes da inclusão de “+”, era em relação à compensação financeira direcionada aos que reduziram suas taxas de desmatamento (ver Anexo V -

\footnotetext{
${ }^{32}$ Apresentou-se aqui a questão dos contratos de REDD+ que ameaçaram os direitos dos povos indígenas, porém existe uma diversidade de iniciativas nesse sentido, como os projetos apoiados pelo Fundo Amazônia e o Projeto Carbono Florestal Suruí, que funcionam de maneira bastante diferente.
} 
“Carta de Cuiaba sobre el cambio climático y los pueblos indígenas", de 2008) - pois isso implica que a compensação seria concedida a quem historicamente desmatou e recentemente parou de fazê-lo, e não para quem, como os povos indígenas, manteve áreas de floresta em pé - essa distorção de REDD é resolvida com o acréscimo do "+" que prevê a compensação também ao manejo sustentável e proteção florestal. Entretanto, a inclusão da compensação para esse tipo de ação é também resultado do posicionamento das organizações da sociedade civil. Em 2008, além de expressar essa preocupação, a COICA também apresentava as seguintes recomendações ou críticas ao mecanismo de REDD que era discutido na época: o reconhecimento dos direitos territoriais indígenas como estratégia de conservação da floresta; a exigência de que ações de REDD considerando as áreas de terras indígenas amazônicas prescindam da conformidade com leis nacionais e diretrizes internacionais relacionadas aos direitos dos povos indígenas; que as autoridades responsáveis (ONU e governos nacionais) proporcionassem as condições necessárias para participação informada de povos indígenas nas discussões sobre clima; e o apoio a projetos indígenas em iniciativas já existentes relacionadas à REDD, como o Fundo Amazônia (vide Anexo V).

Em abril de 2010, organizações da sociedade civil (incluindo diversas organizações indígenas, dentre elas, a COICA) participaram da "Conferencia Mundial de los Pueblos sobre el Cambio Climático y los Derechos de la Madre Tierra" que aconteceu na Bolívia. No documento final desta Conferência, assinado pelas organizações participantes, consta o seguinte parágrafo sobre REDD+:

Condenamos los mecanismos de mercado, como el mecanismo de REDD (Reducción de emisiones por la deforestación y degradación de bosques) y sus versiones $+\mathrm{y}++$, que está violando la soberanía de los Pueblos y su derecho al consentimiento libre, previo e informado, así como a la soberanía de Estados nacionales, y viola los derechos, usos y costumbres de los Pueblos y los Derechos de la Naturaleza. Los países contaminadores están obligados a transferir de manera directa los recursos económicos y tecnológicos para pagar la restauración y mantenimiento de los bosques y selvas, en favor de los pueblos y estructuras orgánicas ancestrales indígenas, originarias, campesinas. Esto deberá ser una compensación directa y adicional a las fuentes de financiamiento comprometidas por los países desarrollados, fuera del mercado de carbono y nunca sirviendo como las compensaciones de carbono (offsets). (Conferencia Mundial de los Pueblos sobre el Cambio Climático y los Derechos de la Madre Tierra 2010, p.6) 
A negativa a REDD (ainda sem o “+”), em acordo com manifestações por parte de movimentos sociais e organizações indígenas até então, refere-se ao entendimento de que REDD, enquanto mecanismo de mercado, promoveria a manutenção dos estoques de carbono das florestas tropicais implicando na ingerência e apropriação das compensações financeiras por parte dos governos locais ou nacionais ou mesmo de empresas privadas ligadas ao mercado de carbono sobre estas áreas e poderia, portanto, comprometer a autonomia das populações locais sobre as áreas que habitavam, violando direitos indígenas conquistados. A garantia dos direitos indígenas permanece uma questão central da proposta de RIA; o que se observa de mudança, dessa Conferencia na Bolívia em 2010 até 2014, é como abordar a defesa dos direitos dos povos indígenas.

Ainda em 2010, a COICA emite documento sobre seu posicionamento a respeito de REDD ("Posición política de COICA sobre REDD”, ver Anexo VI), apresentando a contextualização internacional em que se discute o mecanismo de REDD+, a justificativa para a necessidade de um posicionamento indígena sobre REDD+, vantagens e desvantagens relacionadas a este posicionamento, diretrizes e estratégias propostas pela COICA para incidência política a nível nacional e internacional em relação a REDD+.

Destaca-se da justificativa:

REDD es un mecanismo y una política que va cobrando cuerpo a nivel internacional, principalmente por países industrializados que pretenden utilizar los bosques tropicales como sumideros de carbono a cambio de compensaciones económicas a los Estados posesionarios de dichos bosques. Frente a estos procesos a los pueblos indígenas nos toca la oportunidad de reafirmar lo que siempre hemos reclamado a lo largo de los tempos; la defensa de nuestro território y todo lo que está adentro. Es importante y ya es tiempo que adoptemos a nivel de COICA las medidas que consideremos preventivas a los efectos del cambio climático con nuestras propias fortalezas a través del establecimiento colectivo de uma posición POLITICA sobre cambio climático con mención a REDD. Este instrumento se desprende de la Posición de COICA sobre Cambio Climático (ver en el anexo), adoptado en Cochabamba y consideramos que debe constituirse en un referente regional cuya implementación recaerá en la competência de las organizaciones nacionales miembros de COICA a través de diseño, promoción y desarrollo de ESTRATEGIAS propias de acuerdo a las realidades culturales de sus presentados. (COICA 2010, p. 3) 
A necessidade de um posicionamento indígena frente a REDD é justificada pela COICA no mesmo documento pela restritiva participação de povos indígenas no debate global sobre mudanças climáticas, da qual resultam riscos a seus direitos coletivos apontados pela COICA no mesmo documento; dentre eles, destaca-se aqui a comparação de REDD a outras atividades que tornam os territórios indígenas vulneráveis, como monoculturas e hidrelétricas:

\footnotetext{
Algunas de las medidas de mitigación y adaptación planteadas por distintos actores y agentes que participan en el proceso multilateral de negociaciones de la CMNUCC, podrían generar mayores vulnerabilidades sobre nuestros territórios con directo impacto a los recursos de nuestra subsistencia. La promoción de monocultivos, biocombustibles, represas hidrelétricas, semillas transgénicos, secuestro de carbono, políticas y mecanismos REDD y otros, son alguno de los indicadores del grave problema que tendremos en el futuro los pueblos indígenas si no tenemos una posición clara al respeto. (...) Um problema no discuto a fondo ni socializado a tiempo, trae consecuencias severas sobre el medio ambiente y repercute de manera directa en la vida sócio económico y cultural de los pueblos indígenas, como sucede con las actividades de hidrocarburos, concesiones forestales y proyectos de biocombustibles (COICA 2010, p.3/4)
}

A preocupação com a falta de reconhecimento dos povos indígenas enquanto mantenedores destas áreas de floresta que se tornam valorizadas com o mecanismo de REDD+, mas que foram historicamente e seguem sendo devastadas e desrespeitadas junto aos direitos indígenas por atividades predatórias de um modelo econômico extrativista sem haver um compromisso claro de frear estas iniciativas no âmbito das negociações do clima, ou seja, destaca-se a vulnerabilidade dos povos indígenas e de seus territórios neste contexto e que REDD+ não garantirá nenhuma melhoria para essa condição de vulnerabilidade dos povos indígenas frente às "ameaças externas". Dentre os questionamentos ao mecanismo de REDD+ estão os apontamentos de que as Terras Indígenas não são valorizadas política e financeiramente da mesma maneira que outras áreas protegidas e para a contradição entre a defesa da importância das áreas de floresta nos países amazônicos e o ataque cotidiano aos direitos indígenas e seus territórios. Há ademais presente uma percepção da importância de tomar esse posicionamento antes do final da discussão no âmbito da UNFCCC a respeito do mecanismo, apontando para o risco de que o texto final e a implementação do mecanismo de REDD+ definidos venham a ser prejudiciais aos povos indígenas - “... el resultado final de la política de 
REDD a ser aplicado puede ser muy decepcionante para los pueblos indígenas en cuanto a sus derechos territoriales y los bosques que ocupa." (idem, p. 4)

A partir da apresentação das vantagens e desvantagens para povos indígenas relacionadas ao mecanismo de REDD+, são sugeridas diretrizes para o mecanismo de REDD+ como proposta dos povos indígenas amazônicos. Essas diretrizes são o embrião da proposta de RIA, pois tratam: primeiro, da ação dos povos indígenas para conservar a água, os bosques e o solo como uma ação de mitigação às mudanças climáticas; segundo, que a garantia para essa ação de mitigação dos povos indígenas depende da garantia jurídica de seus territórios e do fortalecimento das formas próprias de governança territorial (relacionadas a outros aspectos sociais, culturais, econômicos, políticos e espirituais) - que são afinal contemplados pela defesa do "manejo holístico dos territórios". Por fim, o documento apresenta como a COICA poderia intervir em relação ao desenvolvimento do mecanismo de REDD na Amazônia, considerando cinco eixos estratégicos: informação (informar e capacitar organizações indígenas amazônicas sobre o tema de mudanças climáticas e REDD+ e coletar insumos sobre o tema junto às bases); normativo (elaboração e apresentação das propostas, critérios e metodologias para o estabelecimento de REDD+ que leve em conta as reivindicações indígenas, incluídas nas legislações pertinentes); organização (acompanhamento das discussões sobre REDD+, desenho de estratégias locais e de intervenção internacional sobre o tema e suporte técnico a organizações base e comunidades); incidência (em que a COICA assume a frente de promover a defesa dos direitos indígenas em fóruns internacionais e junto a instituições diversas, bem como acompanhar o desenvolvimento de políticas e iniciativas de REDD+) e territorial (especialmente em ações ligadas à governança).

Cabe ressaltar que este documento já assinala especial atenção ao Fundo Amazônia, instituído em 2008 e com seus primeiros projetos aprovados em 2009, sendo implementados a partir de 2010. O Fundo Amazônia apoia projetos que auxiliem o controle e redução do desmatamento amazônico, ou ações de conservação e uso sustentável da floresta - sendo portanto uma iniciativa que se pode se enquadrar como ação de REDD+ -, e possui diretrizes para o apoio a povos indígenas, sendo a COIAB parte de seu Comitê Orientador - apesar de, até hoje, apenas uma organização indígena ter conseguido um projeto aprovado pelo Fundo (Projeto “Alto Juruá, da Associação 
Ashaninka do Rio Amônia) $)^{33}$. O fato de a COIAB, como base da COICA, compor este Comitê como parte da sociedade civil organizada é um fator importante para entender o posicionamento da COICA em relação a REDD+. A discussão sobre o Fundo Amazônia entre organizações indígenas no Brasil vem desde 2008, com a participação de COIAB e COICA (vide Anexo VI).

Em 2011, a COICA organiza a "1ra Cumbre Regional Amazónica” em Manaus, realizada entre 15 e 18 de agosto, com o objetivo de discutir a crise ambiental e climática do planeta. Neste encontro são definidas as bases para a proposta de RIA, apresentada na COP17 no mesmo ano em Durban: assegurar o reconhecimento jurídico (titulação e demarcação) dos territórios indígenas - "territorios de vida plena" - como estratégia para reduzir o aquecimento global; a adequação de REDD+ às cosmovisões e direitos dos povos indígenas; a exigência de compromissos efetivos para a redução de emissões de gases de efeito estufa e a necessidade de mudanças no modelo de produção, consumo, distribuição e energia (também parte do contexto de preparação para a Rio+20, que se realizaria no ano seguinte).

O posicionamento da COICA em relação a REDD+ entre 2010 e 2011, descrito acima, apresenta convergência e semelhanças com o posicionamento de outras organizações indígenas, especialmente da América do Norte. A Declaração de Albuquerque (2000) e a Declaração de Anchorage (2009) expressam a preocupação dos indígenas em relação às mudanças climáticas causadas pelas atividades econômicas depredatórias, exigindo das autoridades (ONU e governos nacionais) o apoio à participação indígena qualificada nas negociações do clima, o reconhecimento do papel dos povos indígenas para o enfrentamento das mudanças climáticas e a dívida ecológica dos países desenvolvidos, e a necessidade de ruptura com o modelo de desenvolvimento baseado na queima de combustíveis (ver Anexos VII e VIII, respectivamente). A Declaração de Anchorage já trata especificamente de REDD, destacando a necessidade de as iniciativas de REDD reconhecerem e implementarem os direitos indígenas.

\footnotetext{
${ }^{33}$ Uma das grandes críticas da primeira fase do Fundo Amazônia foi a seus critérios de aceitação de projetos, que tem os recursos geridos pelo BNDES, exigindo dos proponentes capacidade administrativa (de gestão e execução de recursos) que dificulta o acesso ao Fundo por parte de organizações indígenas.
} 


\subsection{O que é RIA?}

REDD+ Indígena Amazônico é uma proposta alternativa ao mecanismo de REDD+ convencional, mas que também tem como um de seus objetivos a redução da emissão de gases de efeito estufa relacionada ao desmatamento evitado. Enquanto em 2011 o movimento indígena transnacional (e nacional no Peru) debatia o mecanismo de REDD+ e tendia a rechaçá-lo, um encontro promovido pela AIDESEP no Peru teve como resultado a definição de "batalhar por dentro" (Espinoza $\left.{ }^{34} 2014\right)$ pelo significado de REDD+. Ou seja, ao invés de tomar um posicionamento favorável ou contrário ao mecanismo de REDD+ discutido na UNFCCC, optou-se por "transformar as ameaças de REDD+ em oportunidades", ou seja, elaborar uma proposta de REDD+ que convergisse com a "agenda permanente dos povos indígenas, condicionando e adaptando [o mecanismo] aos direitos e cosmovisões" (idem) dos povos indígenas.

... la construcción de RIA como una estratégia más eficaz, eficiente y
sostenible de reducción de la deforestación y degradación de los bosques,
control de sus impulsores, almacenamiento de carbono y reducción de la
pobreza, que se supone es el objetivo primordial de REDD+, pero sin caer en
las trampas de la mercantilización y financiarización de la naturaleza ni
supeditando todo a los negociados de la comercialización del mercado
privado de carbono de quienes contaminan. (Espinoza 2014, p. 76)

A diferença pode-se resumir ao fato de que REDD+ coloca apenas a questão do carbono, enquanto RIA alia a redução das emissões advindas do desmatamento e degradação florestal à visão e práticas indígenas que são tratadas a um só tempo como estratégias de mitigação e adaptação às mudanças climáticas; em outras palavras, os modos de vida, cosmovisão e manejo dos territórios indígenas (que são assim denominados de maneira desvinculada pelos não-indígenas, mas que são aspectos combinados na vivência de muitos povos) são em si ações que podem tanto garantir a redução das emissões de gases de efeito estufa estocadas nas áreas de suas florestas (consistindo portanto em ações de mitigação) quanto o conhecimento sobre o território possibilita aos povos indígenas, seguindo a proposta de RIA, estabelecer medidas de adaptação necessárias (seja o cultivo de outras plantas pelas circunstâncias que mudam, outros hábitos de alimentação ou mesmo migrações quando necessárias). Assim, RIA

\footnotetext{
${ }^{34}$ Roberto Espinoza é sociólogo peruano, membro da AIDESEP e parte da equipe técnica da COICA.
} 
coloca o conhecimento indígena, sua maneira de viver e estar no mundo e sua relação com a terra no centro da proposta para um mecanismo de compensação financeira que prevê o pagamento por resultado (ou seja, o pagamento pela quantificação do carbono não emitido).

Com a adoção das salvaguardas ${ }^{35}$ para REDD+ na COP16 em 2010 fica estabelecida oficialmente a necessidade de se respeitar os direitos dos povos indígenas e a importância de sua participação para a implementação de REDD+ a nível nacional; entretanto, a nível internacional não foram definidas estruturas claras para garantir essas salvaguardas. A proposta de RIA para a bacia amazônica pode contribuir para o estabelecimento das salvaguardas para os povos indígenas da região, e demonstra que é "realista incluir a visão dos povos indígenas na construção de metodologias e desenhos nacionais para REDD+" (Pugley 2014, p. 11).

Em 2011, a COICA apresentou na COP17 a proposta "Gestión Holística de Territorios de Vida Plena - REDD+ Indígena" com elementos que deveriam ser agregados ao mecanismo de REDD+ que seguia em discussão na UNFCCC:

\section{Qué es REDD+ Indígena Amazónico?}

Es una iniciativa que busca valorar la integralidad de los servicios ecosistémicos de los bosques y territorios indígenas, que vá mas allá de la captura de carbono en aquellas áreas com mayor amenaza de deforestación, y más bien, invita a adoptar una visión integral y de amplio enfoque para incorporar otros bienes y servicios que brindan los bosques.

REDD+ Indígena Amazónico es una contribución a la construcción del mecanismo REDD+ que no sólo busca dar prioridad a la conservación y manejo de los bosques y territórios para nuestra vida, sino que impulsa la cooperación, y propone alternativas para hacer frente al cambio climático con la participación equitativa de los pueblos indígenas y de los países industrializados. (...)

Qué actividades se ejecutarían?

- La implementación de "Planes de Vida" que garantisse mantener el bosque em pie, con usos adecuados: agroforestal, hidrobiológicos, artesanía, turismo vivencial, medicinal y ecológico, entre otros.

\footnotetext{
${ }^{35}$ Salvaguardas são medidas que devem ser tomadas para a implementação de REDD+ de maneira a minimizar possíveis impactos negativos advindos da adoção deste mecanismo. Sete salvaguardas foram definidas na COP16, sendo uma delas a promoção da participação plena e efetiva dos povos indígenas nas ações de REDD+.
} 
- Contratos fuera de mercado de créditos de carbono, con plazos de corta duración y reajustes anuales de aprendizajes.

- Dar garantias del respeto de Derechos Indígenas: seguridad territorial, acceso y usos consuetudinários, gobernanza autónoma, propriedad intelectual.

- Monitoreo y macro medición de carbono con imágenes satelitales, parcelas de campo, inventários de diversidad de biomasa.

- Vigilância comunal para el control de "fugas y drivers" (de carbono) en el entorno: colonización, agro-negocios, industrias extractivas, megaproyectos, bio-combustibles. (COICA 2011a, folder)

As atividades de RIA propostas são adequações sugeridas ao mecanismo de REDD+ para sua implementação junto a povos indígenas: a revisão dos formatos de contratos de carbono, a garantia aos direitos dos povos indígenas, uma abordagem mais ampla do território e dos elementos ali presentes (além do carbono), a atenção às ameaças do entorno e a importância da autonomia dos povos indígenas para a manutenção das florestas (pela "implementação dos planos de vida").

Desde a primeira apresentação de RIA na COP17 em 2011 até a proposta submetida à $\mathrm{COP} 20^{36}$, RIA foi se reconfigurando, à medida que o debate sobre REDD+ avançava tanto nas negociações oficiais quanto a nível local entre as bases da COICA ainda que os aspectos centrais da proposta, descritos acimas, tenham sido mantidos.

Em 2012, além da definição de RIA em eixos e atividades (conforme apresentada na COP17), foram definidas Terras Indígenas para a implementação de experiências-piloto de RIA em cinco países da bacia amazônica. Na COP18 no Qatar (2012), a COICA apresenta as experiências-piloto como uma nova etapa de ação de RIA e como maneira de demonstrar a eficácia e sustentabilidade dos territórios indígenas para a manutenção das funções ecossistêmicas da Amazônia. O propósito geral das experiências-piloto de RIA era demonstrar que as iniciativas indígenas de manejo territorial poderiam ser consideradas como estratégias efetivas de mitigação e adaptação às mudanças climáticas, promovendo a manutenção de áreas de floresta e a utilização do

\footnotetext{
${ }^{36} \mathrm{Na}$ COP21 em 2015, a COICA trouxe outras propostas, relacionadas a Fundos Indígenas e Planos de Vida - que tem como cerne, semelhante à RIA, a importância do conhecimento indígena para manejo sustentável de seus territórios e sua necessária valorização, considerando contextos nacionais que ameaçam os direitos, cultura e vida dos povos indígenas na bacia amazônica.
} 
conhecimento tradicional para a adaptação dos povos indígenas aos impactos sentidos de mudanças climáticas. Além disso, segundo a proposta apresentada na COP18,

El objetivo específico [de RIA es] fortalecer el saneamiento y consolidación territorial de los pueblos indígenas, y de su manejo y gestión territorial a través de implementar experiencias piloto de "Redd+ Indígena Amazónico" (RIA) en territorios indígenas de al menos 4 millones de Has. de bosque tropical em 05 países (Brasil, Perú, Colombia, Bolivia y Ecuador) que produzcan aprendizajes para la sistematización y validación de la propuesta $y$ potenciar su incidencia en los procesos nacionales e internacionales sobre Redd+ [grifo meu]. (...) Es un plan a ser adaptado a la realidad específica de cada território y Pueblo indígena, luego de ser socializado, debatido y validado por las asambleas y estructuras organizativas comunitárias. El plan es a nivel local, pero com conexiones y propuestas de cambio de las estratégias sobre Redd+ a nivel nacional o sub nacional. (COICA 2012, folder, p. 7)

Em termos práticos, RIA deve adequar-se a cada país e contexto, pois os eixos centrais são demasiado abrangentes para guiar qualquer tipo de ação mais concreta. Mais do que a implementação de projetos de RIA (num paralelo com projetos de REDD+), as experiências piloto foram tentativas de estabelecer as conexões possíveis entre a proposta conceitual e abrangente de RIA para contextos locais diversos e de estabelecer diálogos sobre REDD+ junto aos governos como uma forma de adequação intercultural sobre REDD+ para as políticas públicas (nacionais e sub-nacionais) de REDD+. Entre 2013 e 2014, foram realizadas reuniões para definir os locais das experiências piloto e encontros posteriores para o desenvolvimento das experiências piloto, sendo acordadas as seguintes localidades ${ }^{37}$ :

- Peru: Reserva Comunal Amarakaire (localizada no Estado de Madre de Dios) organização indígena responsável: FENAMAD;

- Colômbia: Resguardo Cuenca Media y Alta del Río Inirida (localizada no Estado de Inirida) - organização indígena responsável: OPIAC;

- Brasil: Terra Indígena Igarapé Lourdes (localizada no Estado de Rondônia) organização indígena responsável: Padereehj;

\footnotetext{
${ }^{37} \mathrm{Na}$ COP18, a COICA apresenta as experiências-piloto de RIA em localidades diferentes destas: no Brasil, inicialmente foi considerado que os Sateré Mawé implementassem um dos piloto de RIA; a Bolívia, considerou-se a princípio o território Itanoma; e no Equador ainda não havia definição sobre qual seria a localidade para implementação da experiência piloto. A indicação posterior das organizações regionais base e interesse das organizações locais guiou a definição das localidades dos pilotos de RIA.
} 
- Equador: Bosque Kutukú-Shaimi (localizada no Estado de Morona Santiago) organização indígena responsável: FICSH;

- Bolívia: Movima (localizada no Estado de Beni) - organizações indígenas responsáveis: SC Pueblo Movima/CIDOB.

Para possibilitar a implementação de RIA em cada região da bacia amazônica, seria preciso determinar critérios a partir das informações locais, tais como: quais são os principais problemas a serem enfrentados pelos povos indígenas em cada região/país? Quais são as barreiras para a implementação específica de REDD+ (governança, recursos humanos)? Além disso, seria preciso definir localmente as linhas de base, os serviços ecossistêmicos de cada território, uma estrutura de repartição de recursos advindos de REDD+, a definição de uma estratégia de manejo (quando não houver) e a contextualização do marco legal nacional em que o territórios indígena se insere. As experiências piloto de REDD+ serviriam para responder a estas questões, mais do que para funcionar como locais de implementação de projetos de REDD+. Tomando como referência o documento sobre as experiências-piloto elaborado pela COICA em 2012, que apresentava dez aspectos necessários para a implementação das experiências-piloto, os avanços de RIA em cada localidade podem ser agrupados conforme o quadro abaixo. 


\section{BOL BRA COL EQU PER}

\begin{tabular}{|c|c|c|c|c|c|}
\hline $\begin{array}{l}\text { Discussões/Nivelamento local sobre mudanças } \\
\text { climáticas, RIA e negociações do clima }\end{array}$ & $\mathrm{X}$ & $\mathrm{X}$ & $\mathrm{X}$ & $\mathrm{X}$ & $X$ \\
\hline Plano de vida elaborado/atualizado & & $\mathrm{X}$ & $\mathrm{X}$ & $\mathrm{X}$ & $\mathrm{X}$ \\
\hline Diálogo com governos sobre RIA & & & $\mathrm{X}$ & $\mathrm{X}$ & $\mathrm{X}$ \\
\hline $\begin{array}{l}\text { Noções de RIA acolhidas pelos } \\
\text { governos/adotadas em políticas }\end{array}$ & & & $\mathrm{X}$ & & $\mathrm{X}$ \\
\hline $\begin{array}{l}\text { Financiamento para RIA (fundos e mecanismos } \\
\text { já existentes) }\end{array}$ & & & & & $\mathrm{X}$ \\
\hline
\end{tabular}

Figura 2. Avanços das experiências-piloto de RIA por país.

As experiências-piloto tiveram desenvolvimento bastante diferente em cada região por inúmeras razões (apoio externo ${ }^{38}$ para a discussão sobre REDD+ em cada país, maior proximidade da COICA das organizações-base, demandas regionais, entre outros). No Brasil, por exemplo, a experiência-piloto em Igarapé Lourdes teve como foco o Plano de Gestão Territorial e o nivelamento sobre REDD+, considerando os avanços das políticas públicas do país (tendo a Política Nacional de Gestão Territorial e Ambiental de Terras Indígenas já instituída e a Estratégia Nacional de REDD+ ainda em elaboração) e os interesses e possibilidades comunitários para RIA. Já o Peru, sede da COP20 (e por isso uma importante responsabilidade a respeito da questão climática pairava sobre ele no ano de 2014 , no qual teria que também apresentar um forte posicionamento oficial) e local onde um número considerável de atividades do Programa de REDD+ da ONU (UN REDD Programme) foi realizado junto a povos indígenas, foi o país onde a experiência-piloto de RIA mais avançou: foram destinados recursos do Plano de Preparação de REDD+ do Peru e do FIP para a titulação territorial e manejo territorial; o FIP (Forest Investment Program, fundo multilateral que tem um mecanismo dedicado à povos indígenas), que apoia a implementação de REDD+ no país junto a Ministérios (de Meio Ambiente, Agricultura, e outros), incluiu a AIDESEP e a Confederación de Nacionalidades Amazónicas del Perú (CONAP) como parte de seu Comitê Diretor Nacional (Espinoza, 2014).

Em 2013, a COICA concentrou seus esforços na difusão de informação e na construção das experiências-piloto, cujos avanços - especialmente no Peru - foram

\footnotetext{
${ }^{38}$ Especialmente do Programa de REDD+ da ONU, GTZ e WWF.
} 
apresentados na COP19. Acompanhei dois destes seminários: um nivelamento sobre mudanças climáticas e REDD+ na Guiana Francesa em 2013 e um encontro para discutir as experiências-piloto no Brasil em 2014. Nestes encontros, ficou evidente o quanto as diferenças regionais determinaram a condução ou pouca atenção dada à RIA e às experiências-piloto: na Bolívia, por exemplo, os atritos com o governo (especialmente em relação ao Territorio Indígena y Parque Nacional Isiboro-Secure TIPNIS) e as enchentes de 2013 na região de Beni resultaram em mais atenção a questões de adaptação e pouca importância dada à REDD+ e RIA; no Brasil, a difusão dos riscos associados a REDD+ exigiu (e ainda exige) mais debate e informação sobre riscos e benefícios, resultando em ausência de posicionamento das organizações indígenas a esse respeito (o que indiretamente freou o debate de RIA); no Peru, as ameaças aos territórios indígenas e a presença da AIDESEP e do Programa de REDD+ da ONU impulsionaram o avanço de RIA associado à defesa dos direitos indígenas e titulação territorial.

Em 2014, com a realização da COP20 no Peru, COICA e AIDESEP conseguiram maior participação de representantes indígenas amazônicos e um espaço dedicado à discussão e apresentação de propostas dos povos indígenas - o Pavilhão Indígena (Pabellón Indígena). O Pavilhão Indígena teve programação composta por mesas-redondas promovidas exclusivamente por organizações indígenas (ainda que as mesas pudessem contar com a participação de representantes de agências e organizações não-indígenas) e reuniu mais de cem lideranças indígenas amazônicas. O Pavilhão Indígena não estava dentro do espaço oficial da COP20, mas em outro local aberto à sociedade civil, junto ao espaço "Vozes pelo Clima", com exposições e stands; havia transporte disponível entre o espaço oficial e o Pavilhão Indígena. As atividades do Pavilhão ocorriam paralelamente às do espaço oficial e no mesmo período, de 2 a 12 de dezembro de 2014. Além da organização do Pavilhão Indígena, inédito até então nas COP, em 2014 a COICA submeteu uma proposta de RIA à UNFCCC, "REDD+ más allá del carbono" (ver Anexo IX), com conteúdo atualizado dos aspectos centrais de RIA (acompanhando a evolução da discussão sobre REDD+ dada pelo Marco de Varsóvia em 2013) e com mais detalhes sobre cada aspecto - a proposta de RIA já havia sido apresentada em side-events (eventos destinados à apresentação de projetos e propostas da sociedade civil organizada, que ocorrem dentro do espaço oficial), porém 
apenas em 2014 a COICA submeteu previamente sua proposta de RIA à UNFCCC, oficializando RIA.

A partir da leitura dos documentos reunidos nesta pesquisa produzidos pela COICA sobre RIA, as principais mensagens da proposta são:

1. Garantia dos direitos dos povos indígenas reconhecidos internacional e nacionalmente, especialmente o reconhecimento dos territórios indígenas (por meio da titulação ou demarcação dos territórios), como premissa para implementação de REDD+ em áreas indígenas;

2. Manejo territorial holístico: visão integrada do território, que leva em conta as funções ecossistêmicas dos territórios indígenas como um todo, tomando em conta a inter-relação entre diversidade cultural e biológica, ou seja, a “interdependência entre povos indígenas e ecossistemas e bosques amazônicos" (e não apenas o armazenamento de carbono e a redução das emissões de gases de efeito estufa). RIA deve reforçar (e não tirar) a autonomia dos povos indígenas para definir os rumos de seu próprio "desenvolvimento" e a gestão de seus territórios a partir de seus valores e paradigmas, por meio da implementação dos planos de vida. A conservação dos territórios e de suas funções ecossistêmicas passa, portanto, por assegurar aos povos indígenas o controle sobre seus territórios de maneira integral: solo, subsolo e águas. O manejo territorial indígena, garantido pela autonomia das comunidades, é a melhor maneira de armazenar carbono (em oposição às reservas de carbono em outros tipos de área verde, como plantações ou "desertos verdes" (áreas de monocultura de árvores): uma floresta diversa e rica em biodiversidade deve ser mais valorizada que áreas verdes com a função única de estocar e sequestrar carbono.

3. Macro-medição sistêmica: da mesma maneira que a manutenção do território não deve se restringir à manutenção do estoque de carbono, as medições não devem ser feitas apenas para o carbono, e sim contabilizando todas as funções ecossistêmicas do território. Coloca-se em pauta também a forma como a medição é feita, diferenciando as macro e micro medições em relação às metodologias utilizadas. 
4. Fundos públicos para financiar RIA: as dinâmicas de mercado (flutuações, lógica de lucro) e a especificidade do carbono como "commodity intangível" configuram a imprevisibilidade do mercado de carbono. Essas características de funcionamento do mercado de carbono financiamento tornam a negociação e gestão de recursos para RIA mais complexa e arriscada. A regulamentação estatal para implementação de REDD+ representa riscos menores de conflitos socioambientais do que o mercado de carbono guiado pela livre concorrência; existe o receio de que, com crises econômicas internacionais, os mercados de carbono percam recursos e os programas de REDD+ percam financiamento, deixando iniciativas inacabadas. O financiamento público de REDD+ (ou que passe pela regulamentação dos Estados) é visto como maneira de assegurar que os programas de REDD+ serão menos afetados pelas oscilações de mercado e respeitarão as legislações nacionais e direitos dos povos indígenas nelas previstos.

5. RIA e REDD+ como secundários diante de um esforço global real pela redução de emissões de gases de efeito estufa: Compromisso e cobrança da ação de outros agentes para a manutenção do equilíbrio climático, reconhecendo, de um lado, a contribuição dos povos indígenas e, de outro, a dívida ambiental histórica advinda do modo de produção capitalista: Combate ao desmatamento e outras atividades predatórias (de infraestrutura a petroleiras e atividades agroextrativistas ou agropecuárias) no entorno de Terras Indígenas, pois a persistência desses resulta em ameaças graves aos territórios indígenas. RIA explicita a necessidade de outras ações para mitigação, deixando claro que a implementação de RIA ou REDD+ não deve servir para diminuir os esforços mundiais para redução de emissões em outros setores - do contrário, REDD+ ou RIA seriam apenas uma falsa solução para manter atividades altamente emissoras de maneira irresponsável.

6. Reconhecimento de RIA e do conhecimento indígena como estratégia de mitigação e adaptação às mudanças climáticas: a cosmovisão e gestão territorial dos povos indígenas significa, de um lado, o manejo sustentável de áreas de floresta (ação de mitigação) e, de outro, uma percepção diferenciada sobre as mudanças climáticas e possibilidades de responder a essas mudanças 
(espécies de plantas e animais a cultivar, por exemplo, como estratégia de adaptação que garanta sua segurança alimentar).

\subsection{Protagonismo indígena: da reação à proposta}

Em um contexto em que ainda se discutia como seria um mecanismo de REDD+ (entre 2010 e 2013), a proposta de RIA serviu para mostrar o protagonismo e autonomia de povos indígenas nas discussões sobre clima e como modelo para as salvaguardas de REDD+ a nível nacional para os países que fazem parte da bacia amazônica, uma proposta que, se incorporada às políticas nacionais de REDD+ dos países amazônicos, poderia responder às principais reivindicações feitas por organizações indígenas engajadas no debate sobre este tema.

RIA cumpriria, neste caso, uma função mais normativa e menos de ação; após acompanhar o desenvolvimento e desdobramentos de RIA, inclusive as experiênciaspiloto (mais e menos exitosas), avalio que RIA tem maior potencial em oferecer um subsídio para as definições ainda em aberto sobre REDD+ em relação às salvaguardas e co-benefícios $^{39}$ da implementação de REDD+ para povos indígenas. Considerando de um lado a resistência de países (da União Europeia, por exemplo, financiadores do mecanismo de REDD+) em aceitar "pagar" por co-benefícios, e de outro, o interesse em países implementadores de REDD+ e de outros atores em ampliar a gama de benefícios adicionais à possível implementação de mecanismos de REDD+, a proposta de RIA é relevante e presente nas negociações oficiais, o que reforça a importância dos povos indígenas e os resultados que eles esperam da implementação possível de REDD+.

\footnotetext{
REDD+ Indígena es visto como una de las principales propuestas de la jurisdición más grande y mejor ubicada en el sistema de Naciones Unidas para asumir el reto de construir uma alternativa eficaz a REDD+ convencional pensada por y para los pueblos que viven en los bosques. Em um contexto donde el énfasis está puesto en la medición de resultados (y la unidad de medida de éstos se define como las toneladas de carbono captadas o evitadas, expressadas en la biomasa forestal) REDD+ Indígena ofrece una
}

\footnotetext{
${ }^{39}$ São chamados "co-benefícios" os benefícios que potencialmente são alcançados pela implementação de REDD+ além da manutenção dos estoques de carbono florestal, como a conservação da biodiversidade, melhorias da condição social de comunidades, etc.
} 
alternativa que atrae la atención de diversos actores insatisfechos con las limitaciones y riesgos que puede acarrear REDD+ convencional desde una mirada global. (Pugley 2014, p. 31)

Assim, RIA auferiu às organizações indígenas o reconhecimento destas enquanto atores que podem negociar e planejar ações conjuntas com outros em relação a mudanças climáticas e REDD+ - ou seja, apresentar RIA garantiu às organizações indígenas proponentes o reconhecimento enquanto parceiros e interlocutores diretos com Estados nacionais, agências financiadoras e outras organizações.

3.4 "Falar a língua do outro", fazer-se ouvir: tradução e mediação

3.4.1 A configuração de um discurso político indígena: escolhas e críticas

No final da década de 1980, Davi Kopenawa ganha projeção internacional como ambientalista e representante/porta-voz dos povos amazônicos, por sua capacidade de sintetizar as ameaças a seu povo junto à enunciação da "natureza indígena conservacionista", no contexto em que os não-indígenas ao redor do mundo passam a identificar os povos indígenas como "guardiões naturais das florestas". Para se comunicar com não-indígenas de maneira que eles entendam, mas mantendo alguma especificidade de seu povo, Kopenawa "cria" uma intepretação a partir de adaptações que permitam correspondências entre visões de mundo totalmente diferentes, um trabalho que confere "legitimidade étnica" a seu discurso:

I like to explain these things to the whites, so that they may know... This sacred place, the high mountains, the beautiful mountains, are places of spirit. Now "spirit" (espirito) is not a word in my language. I have learned this word spirit and use it in the mixed language I have invented [to talk to whites about these things], but my own indigenous word is herukabe; [also] saboribe [literally, "old gardens"]. These are the spirits of shamans (sabori) who live in the mountains. (Turner and Kopenawa apud Graham 2002, p. 204)

De acordo com Graham (2002), o potencial e êxito dos discursos de Kopenawa residem em sua habilidade em articular as preocupações próprias (locais, de um povo) a questões mais abrangentes (do público em geral, de outros povos). Albert (1995) apresenta como o discurso política indígena se constituiu nas últimas décadas do século XX a partir da análise da trajetória e constituição da fala de Davi Kopenawa, xamã Yanomami que lutou pela demarcação das terras de seu povo em associação a ONGs. O autor afirma 
haver uma "reelaboração cosmológica" que articula as categorias indígenas e nãoindígenas: a partir do observado junto aos Yanomami, descreve como ocorre uma mudança na perspectiva Yanomami de ver o mundo - o 'branco', antes tido como subhumano, passa a ser um ser inteligível, cujas categorias de percepção do mundo tornamse compreendidas e utilizadas. Acompanhada dessa mudança da percepção sobre o 'branco' e suas categorias vem uma mudança na postura Yanomami em relação a estes que define como o discurso político se transforma de uma forma de 'resistência etnocêntrica' - ou seja, do fazer o "discurso sobre o que é o outro [branco] para si” para uma "etnicidade adaptada": fazer um "discurso sobre si para o outro" (idem). Assim, entende-se o discurso político indígena contemporâneo como constituído a partir da reconstrução simbólica de categorias próprias e externas (a do interlocutor nãoindígena) que reconfiguram não apenas o discurso mas a (cosmo)visão e o posicionamento indígena a partir destas.

Entretanto, dependendo da linguagem utilizada pelos representantes indígenas, estes se colocam passíveis do rótulo de "representantes ilegítimos" de seu povo: a utilização de termos e recursos não-indígenas é por vezes considerada um indicador da falta de autenticidade ou "contaminação cultural" do enunciador indígena, levantando suspeitas a respeito de sua etnicidade e da veracidade de sua fala (Graham 2002). Pelo mesmo motivo (a linguagem utilizada que incorpora noções externas), uma liderança indígena que circula em esferas nacionais e internacionais pode ter igualmente sua legitimidade comprometida dentro de sua comunidade. Em resumo essas críticas referem-se aos seguintes aspectos: primeiro, à autenticidade da "indianidade" do enunciador (sob os rótulos de "aculturado"); segundo, à legitimidade do enunciador enquanto representante de um povo (não representa os interesses do(s) povo(s) que afirma, e sim os seus próprios); e terceiro, à "manipulação do discurso", que não seria elaborado pelo enunciador, e sim por outros sujeitos interessados (organizações ou pessoas não-indígenas: ONGs, antropólogos, missionários).

Considerando que o discurso político indígena tem como interlocutor o(s) nãoindígena(s), a combinação entre categorias indígenas e não-indígenas é o que garante a própria viabilidade política do discurso, permitindo, de um lado, a inteligibilidade deste pelo uso de categorias, conceitos e percepções familiares aos não-indígenas e, de outro, a apresentação dos conceitos e visão de mundo indígenas que conferem o caráter étnico 
e, portanto, específico enquanto contraponto aos interlocutores não-indígenas. Sem essa combinação de categorias, que reflete uma habilidade do enunciador indígena por vezes mais ou menos exitosa de um complexo trabalho de tradução e mediação entre visões de mundo distintas, o discurso político indígena estaria fadado ao fracasso - seja pela inabilidade de conseguir estabelecer comunicação com "o outro" por utilizar apenas conceitos próprios, seja pela ausência de conceitos próprios que possam fazer perceber a importância da reivindicação por uma especificidade étnica (Albert 1995). Assim é que Albert (1995) descreve o discurso de Kopenawa, marcado pela caracterização de "ambientalista", como um "dispositivo de tradução cultural estratégico", capaz de dialogar com pressupostos políticos e jurídicos, sendo essa a maneira pela qual uma liderança indígena pode ser ouvida nestes que Albert chama de "espaço[s] político[s] e simbólico[s] [inseridos] num campo de forças interétnico sem muitas alternativas" (idem p. 22).

Quando falamos dos representantes da COICA não estamos falando de lideranças como Davi Kopenawa; a escolha de linguagem da COICA é outra. A opção da COICA não é por fazer menções à visão de um povo, pois não se trata de representar um povo, mas uma região onde habitam vários povos. Nesse sentido, os representantes da COICA só podem partir de uma "indianidade" genérica, fazendo referencia a pontos que unem os povos da bacia amazônica, sem utilizar conceitos de um ou outro povo (similar à maneira como organizações indígenas de outras partes do mundo fazem, como observado nas Declarações de Anchorage e Albuquerque):

\footnotetext{
Los pueblos indígenas y la naturaleza somos unos solo, y por eso, estamos obligados a mantener los bosques en pié, reducir la deforestación y ser guardianes de sus servicios como el agua, biodiversidad, clima para la sobrevivencia de la Vida. Solo pedimos que nos dejen trabajar en paz en nuestra misión. (...) Los Pueblos Indígenas Amazónicos, caminando sobre la huella de nuestros ancestros, pedimos al mundo abrir sus corazones y sueños y unirnos en las jornadas por la Vida, para Todas y Todos. (COICA 2011b, p. 4)
}

O papel da COICA, enquanto representante de etnias diversas, refere-se a um indígena abstrato que cabe na esfera de atuação desta - negociações internacionais onde se trata de uma diversidade de países e contextos de maneira igualmente ampla e abstrata, para que a concretude se realize em outro espaço. Por isso, não era de se 
esperar que a COICA manejasse um discurso com termos da língua nativa de seus representantes, ou com menções à cosmologia de uma etnia - no fim, a COICA opera em um espaço onde a menção aos povos indígenas deve ser feita como um todo, para a garantia e respeito de direitos abrangentes o suficiente para vários povos.

A COICA, por outro lado, ilustra um exemplo de atuação adaptada a esses fóruns, ou seja, com a necessária adaptação de suas maneira de agir e falar condizentes com os espaços que ocupa, realizando práticas de articulação e lobby, e utilizando em seu discurso a combinação de argumentos técnico-políticos, que ressoam entre os nãoindígenas que fazem parte desse universo sui generis da atuação nas negociações internacionais indígenas, utilizando formas de apresentar suas reivindicações e suas justificativas de maneira a combinar o discurso indígena com argumentos “científicos"/econômicos:

\begin{abstract}
No aceptar que la "Economía Verde" sea la combinación de neoliberalismo desarrollista con "proyectos verdes" sino un cambio profundo con reducción del consumismo, despilfarro y depredación y el cambio del patrón de producción, consumo, distribución y energía (hidrocarburos, biocombustibles) con alternativas de armonía entre sociedades, culturas y naturaleza;

Renovación del protocolo de Kyoto, donde haya compromisos firmes y exigibles, de reducción de gases de efecto invernadero y con espacios de participación de los pueblos indígenas. No dejar al mundo a la deriva con poderes que impongan cuanto, como y cuando reducen sus emisiones. (COICA 2011b, p. 3)

La propuesta del RIA garantiza mitigación, adaptación y las conexiones entre ambos. Los impulsores (drivers) de la deforestación y degradación nacional y global, afectan la pervivencia de los Pueblos indígenas. Nuestros pueblos, resistieron, resisten y resistirán dichos drivers, cualquiera fuera el escenario futuro del Redd+. Los pueblos indígenas, somos culturas dinámicas en permanente "adaptación tradicional" a los ecosistemas amazónicos, y nuestros conocimientos son sustanciales para la "adaptación moderna" como parte de un diálogo de saberes, con la modernidad, en un marco de horizontalidad e innovación.(COICA 2014, p. 4)
\end{abstract}

Fato é que os representantes indígenas, quando em espaços de projeção nacional e internacional, fazem escolhas estratégicas de linguagem (Graham 2002) - como também o faz um presidente, governador ou outro representante oficial de Estadonação. Porque é aceito que assessores escrevam discursos de políticos não-indígenas e se questiona a legitimidade de representantes de povos indígenas se estes não escreveram seus discursos?

If an Indian uses "Western" concepts and words such as "biodiversity" or "ecology" in his speech (words which are relatively recent innovations in 
Western environmentalist rhetoric), he risks accusations of Western corruption. This ideological perspective on language ignores the very public nature of circulating discourse. Other's words and ideas necessarily enter into the speech of those who participate in public spheres. (Graham 2002, p. 201)

Não permitir aos indígenas incorporarem termos de outras culturas aos seus discursos é condená-los ao isolacionismo e, com isso, negar sua presença em espaços de discussão importantes. Voltando ao relato que abriu o capítulo, lembremos que os representantes da COICA só conseguiram fazer-se ouvir em um espaço bastante restrito de discussão (ainda que a mensagem transmitida não tenha sido a planejada) pelo acúmulo de anos a respeito das negociações sobre o clima, dos conceitos ali utilizados e dos procedimentos necessários para participar das COP: a incorporação destes termos e práticas é o que possibilita a eles ter alguma voz - ainda que longe de ser da maneira ideal $^{40}$ - dentro deste espaço.

Graham (2002) argumenta que as críticas à legitimidade de um discurso indígena apontando para a linguagem utilizada (não-autentica, ocidental, manipulada) são baseadas na percepção não-indígena de que a linguagem tem uma relação intrínseca com a identidade, ou seja, que a questão não é tanto como ou o que representantes indígenas falam e sua legitimidade ou não, mas o que não-indígenas atribuem às falas e formas de falar. Aqui cabem duas perguntas: o que é autentico? E até que ponto a fala reflete a identidade? Ainda, sobre a autenticidade, Graham aponta para o caráter colonial do conceito de autenticidade, vinculado a um essencialismo subjetivo que os não-indígenas associam aos povos indígenas: estamos, novamente, diante da questão de como o imaginário estático do que é "ser indígena" influencia a classificação de falas e pessoas como "autênticos" ou não, classificando assim tanto cultura como discursos indígenas como "legítimos" enquanto sinônimo de "puros" (ou seja, não influenciados pela cultura não-indígena) - classificação essa que remete a uma noção de cultura estática, negando seu caráter dinâmico e de construção constante. Ambas as críticas vem, segundo Graham (2002), da nossa necessidade (não-indígena) de categorizar opostos: o autêntico (ou "puro") em oposição ao não-autêntico ("misturado" ou aculturado). "The notion that the integration of 'traditional' or culture-specific themes with new or Western concepts or topics is evidence of 'cultural corruption' or inauthenticity is rooted in the Western penchant for compartmentalization." (p. 211)

\footnotetext{
${ }^{40}$ Idealmente, as COP teriam espaços paritários para garantir maior simetria à participação da sociedade civil e povos indígenas, pois sua participação hoje é muito circunscrita, conforme descrito no capítulo um.
} 
À medida que os discursos políticos interculturais são feitos, o próprio campo semântico dos conceitos mobilizados pelo discurso é afetado pelas adaptações linguísticas feitas por mediadores (geralmente os representantes e intérpretes indígenas que falam sua língua e a dominante que acabam transformando tanto as categorias indígenas quanto as não-indígenas, dado que não existem sinônimos nas línguas para as noções que uma e outra pretendem para vários conceitos). RIA é um exercício mais explícito desse trabalho de tradução: considerando que tratava-se de um conceito ainda em construção - ou seja, ainda em disputa -, o trabalho da COICA nesse campo foi o de incluir sua visão sobre o mecanismo criando um conceito próprio que passa a ser reconhecido e diferenciado - não REDD+, mas REDD+ Indígena. Na medida em que estas categorias são transformadas e dão origem a conceitos adaptados - como "terrafloresta" e REDD+ Indígena -, observa-se a modificação operada não só no campo simbólico indígena como no não-indígena, expandindo os horizontes que cada noção separadamente pode oferecer (Albert 1995). É nesse sentido que podemos analisar os discursos políticos indígenas fora da dicotomia "aculturado versus tradicional", ou "autêntico versus ilegítimo"; nas palavras de Albert (1995), "A criatividade política dos líderes de contato na Amazônia indígena remete a um espaço de relações e referências interétnicas por definição.” (idem, p. 24)

\footnotetext{
Nada nos autoriza a separar estes dois registros em nome de uma suposta "autenticidade", nem a tomá-los por estanques ou antagônicos. Trata-se, ao contrário, de duas faces equivalentes e interdependentes de um mesmo processo de construção simbólica da história imediata. O discurso étnico se legitima fazendo referências ao saber cosmológico, e este por sua vez reconstrói a sua coerência à luz daquele. (Albert 1995 p. 4)
}

3.4.2 Como um sujeito indígena pode fazer política na esfera nacional/internacional?

Muitos indígenas, conscientes da importância de signos que remetam à etnicidade para a legitimação de sua alteridade (étnica), fazem uso de termos e adornos e/ou indumentárias para expressar sua identidade frente à públicos não-indígenas. Esses elementos que compõem a "performance indígena" possuem um valor estético e simbólico apreciado/valorado pelo público não-indígena. A utilização de adornos diversos como forma de legitimidade remete a e reitera o imaginário ocidental do que é indígena, no que Spivak chamou de "essencialismo estratégico" (Graham 2002, p. 206) 
O "efeito perverso" de alcançar a legitimidade através dos símbolos de etnicidade que remetem a esse imaginário é precisamente o fato de que esse mesmo essencialismo que legitima os sinais de indianidade desqualifica o que escapa ao imaginário - que é por vezes o próprio fato de indígenas estarem presentes em alguns espaços ou assumindo posturas proeminentes.

Graham (2002) destaca a singularidade do discurso indígena que é marcado pelas referências a mitos e entidades características de seus povos, sendo este aspecto também parte da performatividade, da "indianidade". A performance da indianidade se dá contextualmente, ancorada em referencias locais e performances anteriores, ao mesmo tempo em que buscam dialogar com as expectativas presentes e futuras.

O exercício de tradução e mediação empreendido por lideranças bilíngues e tradutores nativos vai se aprimorando à medida em que estes enunciadores adquirem experiência e aprendizado sobre o que os não-indígenas querem ouvir, do que resultam "ajustes" importantes ao discurso - ajustes esses que muitas vezes são a diferença entre uma fala bem-sucedida, marcante e uma que passa batido. Graham (2002) relata uma situação que ilustra muito bem esse exercício. O mesmo intérprete Xavante que traduziu a fala de uma liderança tradicional em evento para o governo deixando de fora diversas menções que a liderança fez a mitos e entidades (menções estas que trariam força e peso simbólico ao discurso que, sem isso, pouco repercutiu), Paulo, anos depois participa de uma reunião entre ambientalistas de uma $\mathrm{ONG}$ e anciãos Xavante para discutir o apoio da ONG à comunidade. Enquanto os ambientalistas mostram-se dispostos a oferecer recursos aos Xavante destacando seu papel de protetores da natureza, os anciãos falam sobre as necessidades da comunidade, pedindo tratores, geradores de energia e caminhonetes, o que gerou grande constrangimento para os ambientalistas ${ }^{41}$. Nesse momento, Paulo percebe a situação e trata de intermediar o diálogo, articulando os pedidos dos anciãos a projetos de agricultura intercultural que envolviam também etnobotânica e tecnologias tradicionais mas que, sem outras

\footnotetext{
${ }^{41}$ Esse constrangimento pode ser entendido a partir da discussão que Ramos (1995) apresenta sobre as expectativas das agências e ONGs que trabalham na defesa dos direitos indígenas. A reflexão iniciada por Ramos pode suscitar tantas outras questões para entidades de apoio a povos indígenas: como justificar para agências de financiamento que os povos indígenas queiram agir em algo que não seja a preservação do meio ambiente, que seja diferente da reprodução exata de seus modos de vida tradicionais, como a mecanização da agricultura? Como aceitar o "índio de carne e osso" do qual Ramos fala, um índio que tem direito a ter aspirações tão distantes das imaginadas pelos não-indígenas e que, ainda assim, deveriam contar com o apoio destas entidades voltadas para trabalhar com povos indígenas?
} 
tecnologias, tinham dificuldade de ser implementados. O resultado foi a gravação dessa fala de Paulo, e não da dos anciãos: assim, com alguns ajustes às falas iniciais, tornouse possível um ponto de encontro entre as expectativas dos ambientalistas e dos Xavante. Esse episódio aponta, ademais, para o que Ramos (1995) descreve ao caracterizar a relação entre entidades de apoio aos povos indígenas e os próprios povos indígenas, marcada pela expectativa, por parte dessas entidades, de encontrar e apoiar um "índio modelo".

É esse trabalho de construção de pontes entre as agendas que torna uma liderança indígena em contato interétnico eficaz: sua capacidade de comunicar ao espectador uma combinação entre o que o enunciador falou e o que o espectador espera ouvir.

Paulo clearly understood Western environmentalists' agendas. Going beyond simply translating for his elders, he formulated his own speech, one that closely fit the outsiders' expectations. (...) Here Paulo stepped beyond the bounds of simply translating and upstaged the elders by presenting a proposal that he knew the outsiders would find more palatable (Graham 2002 p. 200/201)

A meu ver, foi precisamente este o trabalho feito pela COICA com RIA (e em tantos outros momentos de sua trajetória como organização indígena): a combinação entre o que os interlocutores (negociadores do clima) queriam ouvir e o que os povos indígenas queriam dizer, utilizando para isto uma mescla da linguagem corrente nas negociações do clima (os termos técnicos e a lógica a eles subjacente, como REDD+, desmatamento evitado e redução de gases de efeito estufa) e da linguagem das organizações indígenas (as reivindicações por terra, autonomia e reconhecimento). Cabe aqui apontar que RIA obteve amplo reconhecimento entre os não-indígenas e ganhou destaque nesse meio externo precisamente por utilizar de maneira exitosa a estratégia de combinação destas categorias (sem entrar na discussão aqui sobre os importantes desdobramentos de assumir esse discurso para o movimento indígena de maneira mais ampla). É relevante destacar também que a repercussão de RIA entre os povos indígenas (amazônicos e não-amazônicos) é bastante diferente que a observada entre os nãoindígenas, ainda que não seja possível no âmbito desta pesquisa avaliar essa diferenciação de maneira mais detalhada; entretanto, foi possível observar que, de maneira general, houve muito menos entusiasmo entre as organizações e povos 
indígenas a respeito de RIA (possivelmente pela complexidade do debate, que exige longas horas; pela polêmica a respeito de REDD+ e de outros mecanismos de compensação financeira, por exemplo), ainda que esta seja uma estratégia acordada entre as organizações.

Um problema que se coloca para a COICA é o questionamento de sua legitimidade não perante os não-indígenas (o que seria esperado de acordo com o proposto por Graham, já que os representantes da COICA sempre falam a "língua do outro"), mas perante os indígenas, recebendo por parte destes diversos questionamentos a respeito de sua representatividade enquanto organização indígena "que fala em nome de" todos os povos da bacia amazônica. A respeito deste ponto, defendo aqui que cabe argumentar em favor da importância política de ter um sujeito político indígena do porte da COICA; talvez a lacuna a ser coberta seja o entendimento sobre qual o papel desempenhado pela COICA, menos como uma organização que dará conta de responder às necessidades de todas as realidades locais dos povos amazônicos e mais como uma organização que dá voz aos interesses comuns a estes povos quando estes se confrontam com os interesses de não-indígenas ${ }^{42}$. Especialmente, a COICA pode desempenhar (e desempenha) ações importantes no sentido de pressionar agentes diversos (de Estadosnação a agências multilaterais) a incluir em suas diretrizes os direitos indígenas e a garantia destes, bem como denunciar sua inobservância, contradições e ameaças aos povos indígenas - que, como vimos, são ameaças afinal bastante comuns apesar da diversidade de contextos e de povos.

Vale reforçar aqui que, uma vez que o diálogo entre indígenas e não-indígenas em espaços políticos oficiais (nacionais e internacionais) é realizado utilizando a linguagem de uma destas partes - a não-indígena -, o simples fato de uma das partes ter domínio mais amplo da linguagem utilizada e, consequentemente ser este diálogo regido por normas em acordo com a racionalidade da mesma parte não-indígena (o que Cardoso de Oliveira chama de "institucionalidade dominadora"), caracteriza um diálogo assimétrico e antiético, se assumirmos a ausência da construção conjunta de uma normatividade comum às duas (ou mais) partes envolvidas no diálogo. Diante da dificuldade prática de viabilizar as condições para um diálogo ético e simétrico a partir

\footnotetext{
${ }^{42}$ É certamente fundamental que as organizações-base da COICA exerçam seu papel de controle social, de maneira a delimitar essa esfera de atuação, e que a diretoria da COICA tenha suas atribuições e limites de atuação bem definidos.
} 
da institucionalização de uma nova normatividade devidamente construída entre as partes envolvidas, Cardoso de Oliveira (2000) assinala o domínio da linguagem hegemônica pelos indígenas como possibilidade real para a superação dessa distorção característica do diálogo intercultural, de maneira que os indígenas possam comunicar de maneira inteligível seus próprios interesses.

\begin{abstract}
(...) muito mais do que conhecedores do idioma português, inglês, francês ou espanhol, essas lideranças são capazes de se movimentar no interior das normas do discurso hegemônico, o que lhes permite conduzir uma argumentação audível e inteligível no interior do campo indigenista, sem serem obrigados a institucionalizar uma nova normatividade sustentadora do diálogo interétnico - algo bem mais difícil de se alcançar. Mas se isso não é tudo (pois infelizmente fica sempre marginalizada desse diálogo a grande maioria da população indígena), também isso não é pouco, se considerarmos que é um fato que deve mostrar um rumo para uma política indigenista voltada para preparar o índio a se tornar um competente interlocutor e não um mero cliente de eventuais benesses do Estado ou mesmo de segmentos da sociedade civil. (p. 227)
\end{abstract}

Ao dominar a linguagem do outro é possível estabelecer outro lugar nas relações dialógicas entre indígenas e não-indígenas, mudando a oposição entre dominante e dominado colocada nestas relações; isto porque, na medida em que as duas partes (indígena e não-indígena) dominam a mesma linguagem, estas ocupam posições mais próximas no diálogo intercultural. A ruptura entre as posições de dominante e dominado nas relações dialógicas (talvez ainda não alcançada, mas possível) pode ser capaz de extrapolar a esfera do diálogo e colocar os indígenas em outro patamar em outras dimensões (políticas, sociais e econômicas) nas relações interétnicas. Nesse sentido, "falar a língua do outro" - não dominando apenas o idioma, como também os conceitos e racionalidade que os perpassam - é, além de um recurso político, a forma que mais se aproxima de alcançar um diálogo real que possibilite a inteligibilidade do enunciado pelas partes envolvidas. 


\section{Considerações Finais}

O período de elaboração e construção da proposta de RIA (2011-2014) mostrou ganhos e potencialidades para o movimento indígena, tais como: fortalecer as demandas indígenas por autonomia, conhecimento e direitos dos povos indígenas dentro do debate sobre mitigação e adaptação a mudanças climáticas; apontar RIA como subsídio aos planos de vida/ gestão territorial, colocando o mecanismo de REDD+ "a serviço" das comunidades indígenas para o manejo de seus territórios; garantir participação e contribuição de organizações indígenas para as negociações sobre REDD+ e para o estabelecimento de salvaguardas socioambientais; reforçar o protagonismo e incidência de organizações indígenas na temática do clima e readequar o mecanismo de REDD+ convencional aos termos propostos por indígenas.

Com o Marco de Varsóvia para REDD+ definido e o avanços das definições de políticas nacionais de REDD+ nos países amazônicos, apresentam-se os desafios relacionados à implementação de REDD+/RIA. O primeiro deles refere-se a garantir a adequação das políticas de REDD+ às noções presentes em RIA que contemplam as demandas indígenas. Assumindo que esse diálogo com o governo seja bem-sucedido e que as premissas de RIA sejam adotadas em políticas nacionais/estaduais de REDD+, é necessário garantir que a implementação de REDD+/RIA a nível comunitário seja adequada aos contextos locais, levando em conta os processos de tomada de decisão comunitários e o fortalecimento da governança local para evitar conflitos internos em relação aos recursos financeiros. Além disso, é preciso manter as associações indígenas locais bem informadas sobre REDD+, RIA e mudanças climáticas, o que já se mostrou bastante difícil mesmo na etapa de construção de RIA, considerando a complexidade destes temas. As organizações mais diretamente envolvidas com esse debate - como a COICA - devem manter suas organizações de base devidamente informadas sobre o andamento dessas questões.

Considerando que uma das fragilidades da COICA é o relativo distanciamento das bases (por dificuldades de comunicação interna) e a falta de informação e acompanhamento de todas as ações da coordenação para controle social, o grande risco que vejo para RIA (a depender de como a proposta venha a ser acolhida por governos, outros parceiros ou por fundos acessados pela própria COICA) é que a COICA (ou a 
coordenação da COICA responsável) perca a legitimidade junto a suas organizações base. Apesar dos encontros de nivelamento sobre mudanças climáticas já promovidos pela COICA, é necessário ainda um trabalho contínuo de discussão e acompanhamento do desenvolvimento de políticas públicas e alternativas de REDD+, que vem se ajustando ao longo de anos. Se, por um lado, é difícil que na prática seja viável manter um trabalho contínuo de formação e atualização sobre as negociações do clima e como elas podem afetar (negativa ou positivamente) os povos indígenas, esse seria um esforço necessário para evitar possíveis conflitos futuros entre organizações indígenas, especialmente considerando que a questão de REDD+ pode envolver um montante significativo de recursos. A qualificação técnica para manejar estes recursos e a proximidade às comunidades e locais que devem ser beneficiadas são necessários para que organizações indígenas como a COICA não percam a legitimidade e acabem atendendo a interesses de pequenos grupos de indígenas, o que enfraquece o movimento indígena de maneira mais ampla (cf. Baniwa 2007). Se, por um lado, cumprir com procedimentos técnicos exigidos pela burocracia de financiamentos é uma forma de garantir a confiança e legitimidade das organizações indígenas dentro e fora das aldeias, esse domínio técnico aproxima-se da incorporação de uma "lógica de escritório" alheia à indígena (Ramos 1995). Assim, a problemática descrita por Ramos (1995) observada nas entidades de apoio ao índio pode hoje ser observada também em organizações indígenas como a $\mathrm{COICA}^{43}$ :

\footnotetext{
O que fazer com a alteridade dos índios, tão pouco afeita à domesticação da lógica do bureau? Como controlá-la e torná-la compatível com os "propósitos impessoais e funcionais" da organização burocrática? Como contornar o descompasso entre a ânsia organizacional das entidades e a necessidade de atuar na interface entre políticas indígenas e políticas brancas? A "vocação" weberiana do escritório não poderia ser menos apropriada para lidar com a questão interétnica. (Ramos 1995, p. 4)
}

É uma necessidade e um desafio para as organizações/movimento indígenas lidar com a institucionalização burocrática, no que se refere à hierarquia e à prestação de contas (Baniwa 2007). Como compatibilizar a burocratização e a alteridade étnica também é um desafio em relação à implementação de RIA após sua possível

\footnotetext{
${ }^{43}$ A COICA domina e age dentro da lógica de escritório descrita por Ramos (1995) sem, no entanto, prescindir necessariamente de entidades de apoio a povos indígenas como intermediários - ao invés de ter essas entidades como intermediários, as tem como parceiros (WWF, Environmental Defense Fund, Forest Trends, para citar apenas algumas), estabelecendo uma relação mais simétrica com essas organizações não-indígenas.
} 
incorporação em políticas públicas (reconhecendo todos os méritos que a proposta tem no plano normativo e político).

Além da burocratização e assunção de compromissos (da prestação de contas a valores éticos como transparência e um "proceder" determinado em relação a como manejar o dinheiro), os recursos de REDD+/RIA exigirão ainda uma contrapartida, seja a manutenção do estoque de carbono, a preservação da área da floresta ou mesmo a manutenção do "modo de vida tradicional". Caso a proposta de RIA não seja apresentada de maneira clara, evidenciando a necessária relação entre a autonomia, autodeterminação e alteridade dos povos indígenas e seus territórios, existe o risco de a contrapartida esperada, no caso dos povos indígenas, seja que estes atendam ao ideal de indígena que se espera deles, do "índio-modelo" ou hiper-real de Ramos (1995) ao "nativo ecológico" (Ulloa 2004): o eterno protetor natural e tradicional da natureza que com ela convive em harmonia. Se uma das críticas a REDD+ convencional é à possível restrição de uso dos territórios indígenas pelos seus habitantes (ferindo assim o direito dos povos indígenas a seus territórios), o problema que se coloca inclusive para a implementação de RIA é um risco de outra ordem, muito menos tangível: neste caso, os povos indígenas estariam sujeitos a uma imobilidade em relação a seu modo de ser, necessariamente atrelada à ideia de "guardiões da floresta" e a outras noções associadas (o bom selvagem, o primitivo, etc.). Por essa razão as questões de autonomia e autodeterminação são tão fundamentais quando se discute REDD+ e RIA. Nesse sentido, falta à proposta de RIA ser mais abordada enquanto uma proposta de etnodesenvolvimento $^{44}$, ou seja, enquanto possibilidade de os povos indígenas decidirem sobre os rumos de seu futuro (Bonfil Batalla 1982), sem precisar atender nem a uma noção unilinear de desenvolvimento (Stavenhagen 1985), nem ao imaginário do índio ecológico.

No campo político em que o movimento indígena está presente (indigenista, ambientalista, climático), Albert (1995) aponta para o limite da "produtividade política" do posicionamento indígena enunciado por meio do exercício de tradução interétnica: o ponto em que nem a visão produtivista da natureza (enquanto recurso) nem a

\footnotetext{
${ }^{44}$ O trabalho de Verdum (2006) apresenta uma perspectiva crítica sobre como o conceito de etnodesenvolvimento tem sido difundido por agências internacionais (especialmente do Norte). Entretanto, pretendo apenas assinalar que a proposta de RIA poderia se fortalecer junto às comunidades indígenas se tomasse em conta a noção de etnodesenvolvimento como proposta por Bonfil Batalla (1982) e Stavenhagen (1985).
} 
conservacionista podem conciliar-se com a visão radicalmente distinta de natureza das cosmologias indígenas.

\begin{abstract}
A partir do momento em que entram na arena política interétnica, os índios, não sem perplexidade, tem que se debater contra esse duplo [natureza civilizada como cenário extrativo ou natureza selvagem como essência] imaginário de Natureza de seus interlocutores brancos. (...) Só nele podem rebater a negação produtivistas de seus adversários e, ao mesmo tempo, se esforçar em traduzir sua própria alteridade nos termos do indigenismo ambientalista de seus defensores - ideologicamente simpático, embora culturalmente equivocado. (...) Exploração ou preservação da Natureza remetem ao mesmo pressuposto de uma Natureza-objeto, reificada enquanto instância separada da sociedade e a ela subjugada. Ora, nada mais estranho que esta separação e este antropocentrismo para as cosmologias das sociedades amazônicas, que fazem do universo uma totalidade social regida por um complexo sistema de intercâmbios simbólicos entre sujeitos humanos e não-humanos... (Albert 1995 p. 19)
\end{abstract}

Assim como "natureza", o conceito de "meio ambiente" parte do mesmo pressuposto de exterioridade e separação em relação ao ser humano, caracterizados, ambos, como fontes de recursos inertes. Porém, é dentro de uma perspectiva de natureza dissociada do ser humano que se apresentam "soluções" ambientais e climáticas enunciadas nas noções de desenvolvimento sustentável, economia verde e mesmo REDD+. Nenhuma delas rompe com a ideia basilar da visão moderna sobre a natureza/meio ambiente como cenário, ponto no qual a percepção indígena diverge radicalmente: lugares dão significado - e não são cenários estáticos - porque tem história, e as histórias dizem muito a respeito de um povo ${ }^{45}$. Apesar dessa divergência fundamental, é pela via ambientalista que os discursos indígenas ganham maior visibilidade e ressonância.

$\mathrm{Na}$ medida em que a COICA, como o movimento indígena de maneira geral, posiciona-se de maneira a romper com a dissociação entre ser humano e natureza/meio ambiente, criticando a racionalidade moderna orientada pelo capitalismo que orienta as relações sociais, políticas e econômicas do mundo globalizado, estes posicionamentos são vistos como reações que se levantam contra a hegemonia do sistema de produção capitalista.

No aceptar que la "Economía Verde" sea la combinación de neoliberalismo desarrollista con "proyectos verdes" sino un cambio profundo con reducción del consumismo, despilfarro y depredación y el cambio del patrón de

\footnotetext{
${ }^{45}$ Basso (1996) descreve como os Apache e seus locais míticos formam um "corpo", segundo uma constituição mútua do lugar e das pessoas, que existem por si sós, mas que se transformam juntos e a partir do encontro.
} 
producción, consumo, distribución y energía (hidrocarburos, biocombustibles) con alternativas de armonía entre sociedades, culturas y naturaleza. (COICA 2011b, Mandato de Manaus, p. 3)

Entretanto, apesar do fortalecimento que esses discursos ganham quando combinados com outros movimentos sociais, entendo que a COICA coloca este tipo de posicionamento de maneira a fazer compreender as reivindicações indígenas nos espaços políticos que ocupa. Nesse sentido, ainda que seja pertinente entender o movimento indígena como não-hegemônico na medida em que os posicionamentos manifestados sejam proposições a partir de uma concepção de mundo distinta e que aponta para alternativas de mundo possíveis, a negativa indígena à hegemonia não tem como foco a ruptura com o sistema capitalista, e sim a garantia de direitos dos povos indígenas que, por estarem ameaçados, prescindem de mudanças no atual sistema. Em outras palavras, o que está presente no discurso político indígena não é a proposta de transformação propriamente dita do modo de vida da sociedade global - como muitos aliados do movimento indígena defendem a partir de seus discursos -, mas a reivindicação do abandono das atividades que, de um lado sustentam esse modo de vida dos povos não-indígenas e, de outro, ameaçam a vida e direitos dos povos indígenas. Assim, o discurso político indígena deve ser analisado de maneira distinta do discurso político indigenista, que enxerga o potencial do movimento indígena para a proposição de novos paradigmas políticos, sociais, civilizatórios e de conhecimento (Stavenhagen 1985, Farrah \& Vasapollo 2011) ainda que este potencial não seja o foco declarado pelo movimento indígena.

Contudo, seria equivocado afirmar que uma proposta como a de RIA assinala para uma aceitação da lógica mercantilista por incorporar (ainda que parcialmente) a ideia de compensar financeiramente a manutenção de estoques de carbono florestal de Terras Indígenas. A proposta de RIA, dentro da atuação política mais geral da COICA, não oferece ruptura nem continuidade em relação ao modelo capitalista hegemônico já estabelecido, escapando à oposição hegemonia versus contra-hegemonia. O presente trabalho tenta mostrar que esta proposta faz parte de um modo de enunciar posicionamentos políticos próprio ao movimento indígena diante de interlocutores nãoindígenas presentes no complexo campo de disputas das negociações sobre mudanças climáticas. Combinar as reivindicações indígenas a temas da agenda mundial em pauta, como o de mudanças climáticas, é uma estratégia política capaz de garantir o reconhecimento ou mesmo valorização da etnicidade e de organizações e povos 
indígenas como sujeitos políticos legítimos que podem, assim, influenciar processos de decisão para além de seus territórios. O fato de representantes indígenas ocuparem assentos em Comitês de decisão sobre políticas nacionais REDD+ no Brasil (com a APIB como membro da Comissão Nacional de REDD+) e no Peru (com a AIDESEP no Comitê Nacional do FIP no Peru) são indicativos dos ganhos políticos dessa estratégia. Assim, RIA e a atuação da COICA de maneira mais geral são aqui assumidos como parte da "retórica do movimento indígena" (Ramos, 1998) de tentar tornar inteligíveis mensagens que refletem o modo de pensar indígena no campo político interétnico institucionalizado.

Ramos (1998) assinala a problemática de a linguagem antropológica criar uma realidade própria ao escrever, descrever e analisar exaustivamente um "objeto" a partir de paradigmas de interpretação; como se a repetição fosse capaz de tornar hipóteses em verdade. O percurso dessa pesquisa mostrou que algumas das hipóteses colocadas inicialmente para compreender RIA (proposta hegemônica ou contra-hegemônica; reflexo de um processo de etnogênese ou resistência indígena) partiam da assunção de um imaginário sobre povos indígenas (conforme indicado no capítulo dois) como fato, e de "enquadrar" a atuação da COICA dentro de classificações (como contra-hegemônica) que, ao final da pesquisa, mostraram-se pouco apropriadas para compreender seus enunciados. Assim, tentei abordar de maneira diferente o posicionamento da COICA, que escapa a estas classificações, e apresentar a atuação política dessa organização de maneira a revelar a especificidade do posicionamento da COICA (que pode se estender a outras organizações de atuação semelhante) e não o seu enquadramento a uma ou outra proposta política já existente no campo político não-indígena. Se essa atuação apresenta similaridades e convergências em relação a conteúdos manejados por organizações não-indígenas, isto não deve necessariamente ser entendido como um reflexo do alinhamento ou cooptação de uma organização indígena, ou de "perda cultural”. Nas palavras de Baniwa (2007), 
mesmo copiado dos brancos, foi sendo incorporado pelos povos indígenas ao longo do tempo, da mesma forma que foram se apropriando de outros instrumentos e tecnologias dos brancos, para defender seus direitos, fortalecer seus modos de vida próprios e melhorar suas condições de vida, que é desejo de toda sociedade humana. Isso não significa tornar-se branco ou deixar de ser índio. (p. 130)

Como Ramos (1998), Albert (1995) e Graham (2002) demonstram, as formas de atuação política de organizações e do movimento indígena podem ser interpretadas como formas eficazes para sujeitos políticos indígenas se fazerem reconhecer como sujeitos legítimos na esfera política interétnica, já que, como Cardoso de Oliveira (2000) aponta, o caminho possível para o reconhecimento e garantia dos direitos dos povos indígenas é, até o momento, que estes ocupem espaços diversos e dialoguem com tomadores de decisão utilizando a linguagem dominante para expressar ideias, valores e visões de mundo e futuro que lhe são próprias. 


\section{Bibliografia}

ACOSTA, Alberto (2011). Sólo imaginando otros mundos, se cambiará éste. Reflexiones sobre el Buen Vivir. In: FARRAH, Ivone; VASAPOLLO, Luciano (org.). Vivir bien: ¿Paradigma no capitalista?. La Paz: Plural Editores.

ALBERT, Bruce (1995). O ouro canibal e a queda do céu: uma crítica xamânica da economia política da natureza. Série Antropologia, n. 174. Brasília. pp. 1-33.

BANIWA, Gersem L. (2007) Movimentos e políticas indígenas no Brasil contemporâneo. Tellus, Ano 7, n.12, pp. 127-146.

BARRETTO FILHO, Henyo T. (1992). Tapebas, tapebanos e pernas-depau: etnogênese como processo social e luta simbólica. Rio de Janeiro: UFRJ.

BARROSO-HOFFMAN, Maria (2005). Do "Brasil sem índios" aos "índios sem Brasil": algumas questões em torno da cooperação internacional junto aos povos indígenas no Brasil. Anthropológicas, Ano 9, v. 16(2), pp. 153-186.

BASSO, Keith H. (1996). Wisdom sits in places: Landscape and. Language among the Western Apache. Albuquerque: University of New Mexico Press.

BECKER, Bertha (2005). Geopolítica da Amazônia. Estudos Avançados, v. 19, n. 53, pp. 71-85.

BELLO, Álvaro (2004). Etnicidad y ciudadanía en América Latina - La acción colectiva de los pueblos indígenas. Santiago de Chile: CEPAL.

BICALHO, Poliene Soares S. (2010). Protagonismo Indígena no Brasil: Movimento, Cidadania e Direitos (1970-2009). Tese de Doutorado. Programa de Pós-Graduação do Departamento de História. Universidade de Brasília.

BLANCO, Gustavo; FUENZALIDA, Maria Ignacia (2013). La construcción de agendas científicas sobre cambio climático y su influencia en la territorialización de políticas públicas: reflexiones a partir del caso chileno. In: Postigo, J. (ed.). Cambio climático, movimientos sociales y políticas públicas. Santiago de Chile: CLACSO. 
BONFIL BATALLA, Guillermo (1972). El concepto de indio en América: una categoría de la situación colonial. Anales de Antropología vol. IX. México: UNAM. pp 105-124.

BRYSK, Alison (1996). Turning weakness into strength: the internationalization of Indian rights. Latin American Perspectives 23(2), pp. 38-57.

CAMARGO, Sonia (1999). Governança global: utopia, desafio ou armadilha? In: NEVES, Carlos Augusto. Governança global: Reorganização da política em todos os níveis de ação. São Paulo: Fundação Konrad-Adenauer-Stiftung.

CARVALHO, Fernanda Viana de (2010). Brasil: de Estado-veto a negociador estratégico. A posição brasileira nas negociações internacionais sobre florestas e clima (1997-2010). Tese de Doutorado. Programa de Doutorado em Política Internacional e Comparada. Universidade de Brasília.

CARDOSO DE OLIVEIRA, Roberto (2000). Ação indigenista, eticidade e o diálogo interétnico. Estudos Avançados, v. 14, n. 40. pp. 213-230.

CASTRO, Fabio; HOGENBOON, Barbara; BAUD, Michiel (coord.) (2015). Governança ambiental na América Latina. Buenos Aires: CLACSO.

CASTRO-GÓMEZ, Santiago; SCHIWY, Freya; WALSH, Catherine (2002). Introducción. In: __ (eds.). Indisciplinar las Ciencias Sociales: Geopolíticas del conocimiento y colonialidad del poder. Perspectivas desde lo andino. Quito: Universidad Andina Simon Bolivar/Abya Yala.

CAYÓN, Luis (2010). Penso, logo crio: a teoria makuna do mundo. Tese de Doutorado. Departamento de Antropologia. Universidade de Brasília.

CHAPIN, Mac (2004). Un Reto a Los Conservacionistas. World Watch, v. 17, n. 6. pp. $2-26$.

CONFERENCIA MUNDIAL DE LOS PUEBLOS SOBRE EL CAMBIO CLIMÁTICO Y LOS DERECHOS DE LA MADRE TIERRA (2010). Carta Final da Conferencia. Cochabamba. 9 pgs. 
COICA (Coordinadora de las Organizaciones Indígenas de la Cuenca Amazónica) (1999). Biodiversidad y Derechos de los Pueblos Indígenas: Manual de Capacitación de Base. Quito: COICA.

COICA (Coordinadora de las Organizaciones Indígenas de la Cuenca Amazónica) (2011a) - Redd+ indígena - gestión holística de Territorios de Vida Plena. Folder, 6 pgs.

COICA (Coordinadora de las Organizaciones Indígenas de la Cuenca Amazónica) (2011b). Mandato de Manaus: Acción Indígena por la Vida. Manaus. 7 pgs.

COICA (Coordinadora de las Organizaciones Indígenas de la Cuenca Amazónica) (2012). REDD+ INDÍGENA AMAZÓNICO: Implementando experiencias piloto. Folder, 16 pgs.

COICA (Coordinadora de las Organizaciones Indígenas de la Cuenca Amazónica) (2014). Redd+ mas allá del carbono y del mercado: integralidade del Redd+ Indígena Amazónico. Submissão da COICA à COP20. 5 pgs.

DUVAL, Fábio Amaro S. (2014). Os movimentos e povos indígenas e a politização da etnicidade na Bolívia e no Peru: das etnogêneses às esquerdas no poder. Tese de Doutorado. Programa de Pós-Graduação Stricto Sensu em Relações Internacionais. Universidade de Brasília.

ESCOBAR, Arturo (1995). Introduction: Development and the Anthropology of Modernity. In: __. Encountering development. The making and unmaking of the Third World. Princeton: Princeton University Press.

ESPINOZA, Roberto (2014). Redd+ Indígena Amazónico: Logros, Avances y Desafíos. In: LÓPEZ, Vladimir; MOLERO MESÍA, María (2014). REDD+ Indígena en el Perú: Perspectivas, avances, negociaciones y desafios desde la mirada de los actores involucrados. Lima: GIZ. pp. 76-81.

FARRAH, Ivone; VASAPOLLO, Luciano. Introducción. In: (org.). Vivir bien: ¿Paradigma no capitalista?. La Paz: Plural Editores, 2011.

GIDDENS, Anthony (2010). A política da mudança climática. Rio de Janeiro: Zahar. 
GUEVARA, Carla; ZANDVLIET, Hans (2013). Las negociaciones sobre Cambio Climático en Naciones Unidas y la realidad de las emisiones. Perspectivas desde el Sur global. In: DELGADO RAMOS, Gian Carlo; ESPINA PRIETO, Mayra; SEJENOVICH, Héctor (Eds.). Crisis socioambiental y cambio climático. Buenos Aires: CLACSO.

GRAHAM, Laura (2002). How Should an Indian Speak? Amazonian Indians and the Symbolic Politics of Language in the Global Public Sphere. In: WARREN, Kay; JACKSON, Jean (eds) (2002). Indigenous Movements, Self-Representation, and the State in Latin America. Austin: University of Texas Press. pp. 181-227.

HILL, Jonathan D. (1996). History, Power, and Identity: Ethnogenesis in the Americas, 1492-1992. Iowa City: University of Iowa Press.

INTERNATIONAL INDIGENOUS FORUM ON CLIMATE CHANGE (2000). Declaration of Indigenous Peoples on Climate Change. Hague. 6 pgs.

IPCC (INTERGOVERNMENTAL PANEL ON CLIMATE CHANGE). Climate change 2007: The physical science basis. Contribution of working group I to the fourth assessment report of the Intergovernmental Panel on Climate Change. Cambridge: Cambridge University Press.

JUSTICIA CLIMÁTICA YA! (2004) Declaración de Durban sobre el Comercio de Carbono. África do Sul, Durban. Disponível em: http://www.fern.org/sites/fern.org/files/media/documents/document 3614_3623.pdf (último acesso em maio de 2016).

KOPENAWA, Davi (2011). A pegada dos napëpë. In: RICARDO, Beto; RICARDO, Fany. (Ed). Povos Indígenas no Brasil 2006-2010. São Paulo: Instituto Socioambiental, pp. 20-23.

MENDOZA, Madeline (2009). Justicia climática: una tarea pendiente. Managua: Centro de Estudios Internacionales.

MIGNOLO, Walter (2002). Colonialidad global, capitalismo y hegemonía epistémica. In: WALSH, Catherine; SCHIWY, Freya \& CASTRO-GÓMEZ, Santiago (eds.). Indisciplinar las Ciencias Sociales: Geopolíticas del conocimiento y colonialidad del 
poder. Perspectivas desde lo andino. Quito: Universidad Andina Simon Bolivar/Abya Yala.

MILANI, Carlos (1999). "Governança global e meio ambiente: como compatibilizar economia, política e ecologia”. In: NEVES, Carlos Augusto. Governança global: Reorganização da política em todos os níveis de ação. São Paulo: Fundação KonradAdenauer-Stiftung.

NIEZEN, Ronald (2003). The origins of indigenism: human rights and the politics of identity. Berkeley: University of California Press.

ONU (ORGANIZAÇÃO DAS NAÇÕES UNIDAS). (1992) Convenção-Quadro das Nações Unidas sobre Mudança de Clima. Nova Iorque. Traduzida por: MINISTÉRIO DA CIÊNCIA E TECNOLOGIA. Brasília: Governo Federal.

PALACIO, Germán (2013). Cambio climático, retórica política y crisis ambiental: una nueva interfase entre ciencias naturales y ciencias sociales. In: Postigo, J. (ed.). Cambio climático, movimientos sociales y políticas públicas. Santiago de Chile: CLACSO.

PINTO, Erika de Paula; MOUTINHO Paulo; STELLA, Osvaldo; CASTRO, Isabel; MAZER, Simone; RETTMANN, Ricardo; MOREIRA, Paula (2010). Perguntas e Respostas sobre Aquecimento Global. Belém: Instituto de Pesquisa Ambiental da Amazônia.

POWLESS, Ben (2012). An Indigenous Movement to Confront Climate Change. Globalizations, Vol. 9, n. 3, pp. 411-424.

PUGLEY, Deobrah D. (2014). REDD Indígena en el contexto de las negociaciones internacionales: Particularidades, ventajas y limites de la propuesta. In: LÓPEZ, Vladimir; MOLERO MESÍA, María (2014). REDD+ Indígena en el Perú: Perspectivas, avances, negociaciones y desafios desde la mirada de los actores involucrados. Lima: GIZ. pp. 8-48.

QUIJANO, Anibal. (2011). ¿Bien Vivir?: entre el ‘desarrollo’ y la descolonialidad del poder. In: ASSIS CLÍMACO, Danilo (2014.). Cuestiones y horizontes: de la dependencia histórico-estructural a la colonialidad/descolonialidad del poder. Buenos Aires: CLACSO 
RAMOS, Alcida (1995). O índio hiper-real. Revista Brasileira de Ciências Sociais, v. 10, n. 28.

RAMOS, Alcida (1998). Indian Voices. In: Indigenism: Ethnic Politics in

Brazil. Wisconsin: The University of Wisconsin Press. pp. 119-144.

SERVINDI (Servicio de Información Indígena) (2005). El fraccionamiento de la COICA. Servindi, Julho de 2005, n. 63.

SILVA, Cristhian Teófilo da (2015). Movimentos indígenas na América Latina em perspectiva regional e comparada. Revista de Estudos e Pesquisas sobre as Américas, v. 9, .n1, pp. 165-206.

SMITH, Richard C. (1996). La política de la diversidad. COICA y las federaciones étnicas de la Amazonia. In: VARESE, Stefano (ed.). Pueblos Indios, Soberanía y Globalismo. Quito: Abya-Yala.

STAVENHAGEN, Rodolfo (1985). Etnodesenvolvimento: uma dimensão ignorada no pensamento desenvolvimentista. Anuário Antropológico 84. Rio de Janeiro: Tempo Brasileiro. pp. 11-44.

STEFFEN, Will; CRUTZEN, Paul J.; MCNEILL, John R. (2007) The anthropocene: are humans now overwhelming the great forces of nature? Ambio, v. 36, n. 8, pp. 614620.

TISOY, Segundo Antonio J. (2011) Historia de Participación de la Coordinadora de las Organizaciones Indígenas de la Cuenca Amazonica en la Agenda Internacional del Convenio de la Diversidad Biológica, en el Artículo 8J y Artículos Conexos. Monografia. Programa de Especialização de Estudos Amazônicos. Universidade Nacional de Colombia.

TORRES, Ramón (ed.) (1997). Entre lo Propio y lo Ajeno. Derechos de los pueblos indígenas y propiedad intelectual. Quito: COICA.

ULLOA, Astrid (ed.) (2011). Perspectivas culturales del clima. Bogotá: Universidad Nacional de Colombia-Ilsa. 
ULLOA, Astrid (2004). La construcción del nativo ecológico. Bogotá: Instituto Colombiano de Antropología e Historia.

VERDUM, Ricardo (2006). Etnodesenvolvimento: nova/ velha utopia do indigenismo. Tese de Doutorado. Centro de Pesquisa e Pós-Graduação sobre as Américas. Universidade de Brasília.

WARREN, Kay; JACKSON, Jean (eds) (2002). Introduction: Studying Indigenous Activism in Latin America. In: ___ Indigenous Movements, SelfRepresentation, and the State in Latin America. Austin: University of Texas Press. pp. $1-46$. 


\section{Anexos}

Anexo I - Lista de organizações indígenas registradas na UNFCCC com status de observadores

\begin{tabular}{|c|c|c|}
\hline AIA & Aleut International Association & EUA \\
\hline & Amazon Alliance & EUA \\
\hline $\mathrm{AAC}$ & Arctic Athabaskan Council & Canada \\
\hline AIPP & Asia Indigenous Peoples Pact Foundation & Tailandia \\
\hline AAT & Asociación AK Tenamit & Guatemala \\
\hline AIDESEP & $\begin{array}{l}\text { Asociación Interétnica de Desarrollo de la Selva } \\
\text { Peruana }\end{array}$ & Peru \\
\hline ARPI-SC & $\begin{array}{l}\text { Asociación Regional de Pueblos Indígenas de la Selva } \\
\text { Central }\end{array}$ & Peru \\
\hline AFI & Assembly of First Nations & Canada \\
\hline CARE & Central Ashaninka del Río Ene & Peru \\
\hline $\begin{array}{l}\text { CAMV - } \\
\text { International }\end{array}$ & $\begin{array}{l}\text { Centre d'accompagnement des autochtones pygmées et } \\
\text { minoritaires vulnerables }\end{array}$ & Congo \\
\hline COCARAE & $\begin{array}{l}\text { Confederación de Organizaciones Campesinas e } \\
\text { Indígenas de la Región Amazónica del Ecuador }\end{array}$ & Equador \\
\hline CONAP & $\begin{array}{l}\text { Confederación de Nacionalidades Amazónicas del } \\
\text { Perú }\end{array}$ & Peru \\
\hline CAOI & Coordinadora Andina de Organizaciones Indígenas & Peru \\
\hline CODEPISAM & $\begin{array}{l}\text { Coordinadora de Desarrollo y Defensa de los Pueblos } \\
\text { Indígenas de la Región San Martín }\end{array}$ & Peru \\
\hline COICA & $\begin{array}{l}\text { Coordinadora de Organizaciones Indigenas de la } \\
\text { Cuenca Amazoniza }\end{array}$ & Equador \\
\hline ECA - RCA & $\begin{array}{l}\text { Ejecutor de Contrato de Administración de la Reserva } \\
\text { Comunal Amarakaeri }\end{array}$ & Peru \\
\hline FEPIKRESAM & $\begin{array}{l}\text { Federación de Pueblos Indígenas Kechwas de la } \\
\text { Región de San Martín }\end{array}$ & Peru \\
\hline FENAMAD & Federación Nativa del Río Madre de Dios y Afluentes & Peru \\
\hline FERISHAM & Federación Regional Indígena Shawi de San Martín & Peru \\
\hline FPCI & $\begin{array}{l}\text { Fundación para la Promoción del Conocimiento } \\
\text { Indígena }\end{array}$ & Panamá \\
\hline GCI & Gwichin Council International & Canada \\
\hline IENTI & Indigenous Education Network of Turtle Island & EUA \\
\hline IPACC & Indigenous People of Africa Coordinating Committee & $\begin{array}{l}\text { África do } \\
\text { Sul }\end{array}$ \\
\hline IAITPTF & $\begin{array}{l}\text { International Alliance of Indigenous and Tribal } \\
\text { Peoples of the Tropical Forests }\end{array}$ & Panamá \\
\hline IITC & International Indian Treaty Council & EUA \\
\hline ICC & Inuit Circumpolar Conference & Canada \\
\hline ITK & Inuit Tapiriit Kanatami & Canada \\
\hline $\mathrm{MNC}$ & Métis National Council & Canada \\
\hline
\end{tabular}




\begin{tabular}{|l|l|l|}
\hline NNTC & National Native Title Council Ltd. & Australia \\
\hline NWAC & Native Women's Association of Canada & Canada \\
\hline NEFIN & Nepal Federation of Indigenous Nationalities & Nepal \\
\hline NAN & Nishnawbe Aski Nation & Canada \\
\hline ORAU & $\begin{array}{l}\text { Organización Regional de la Asociación Inter-Étnica } \\
\text { de Desarrollo de la Selva Peruana Ucayali }\end{array}$ & Peru \\
\hline $\begin{array}{l}\text { Tebtebba } \\
\text { Foundation }\end{array}$ & $\begin{array}{l}\text { Indigenous Peoples' International Centre for Policy } \\
\text { Research and Education }\end{array}$ & Filipinas \\
\hline
\end{tabular}

Fonte: UNFCCC (consulta em março de 2015)

* São consideradas aqui apenas organizações formadas por indígenas e que defendem os direitos dos povos indígenas, sendo desconsideradas organizações de apoio aos povos indígenas e organizações indígenas que tratam de temas específicos, sem o enfoque na defesa dos direitos.

** Assume-se que as organizações indígenas que abriram registro na UNFCCC enviaram representantes como observadores em pelo menos uma COP. 
Anexo II - Declaração de Iquitos

The Iquitos Declaration

\section{COICA}

The Coordinating Body for Indigenous Peoples' Organizations of the Amazon Basin (COICA) invited 15 representatives from 12 environmental groups to meet from 9 to 11 May 1990 at a "First Summit Between Indigenous Peoples and Environmentalists" in Iquitos, Peru. Ten human rights and aid groups, Cultural Survival among them, were invited as observers. The meeting provided an opportunity for indigenous peoples and environmentalists to understand each other's concerns. Both sides attempted to establish a joint strategy for conserving the Amazonian rain forest by supporting indigenous claims for control of their territory and resources. The groups that attended agreed and signed the document that follows, called the Iquitos Declaration.

Plans were made in Iquitos to hold a second "summit" to develop concrete coordinated actions and to continue the dialogue. A committee, made up of representatives from each of the member organizations of COICA and a total of three representatives from environmental organizations, was named, and met in Washington, DC, in September to organize the next meeting.

Having met in the city of Iquitos from May 9 to 11, 1990 between the Coordinating Body for Indigenous Peoples' Organizations of the Amazon Basin (COICA) and environmental and conservationist organizations to analyze the serious deterioration of the Amazon biosphere and look for joint alternatives.

We consider that the recognition of territories for indigenous peoples, to develop programs of management and conservation, is an essential alternative for the future of the Amazon.

We recognize that we must look for adequate mechanisms to reach this objective, that include ways to channel international technical and financial resources.

We recognize the importance of indigenous peoples' own proposals for the management and conservation of the Amazon. 
We recognize the need for actions of diffusion, studies or projects to advance the territorial and societal rights of the indigenous peoples and the recognition of the value of their culture, according to the proposals of COICA and according to the particular objectives of each environmental and conservationist organization.

We conclude that in order that these considerations be put into practice, it is necessary to continue working as an Indigenous and Environmentalist Alliance for an Amazon for Humanity.

We decide to make this joint work concrete through the formation of a provisional Coordinating Committee of the environmentalists that are present and COICA, which will meet in September, 1990, in the city of Washington, D.C., to continue analyzing and designing the best strategies for the defense of the indigenous Amazon.

COICA was founded in 1984 by national Indian organizations of Peru, Bolivia, Ecuador, Colombia, and Brazil.

Fonte: Cultural Survival Quarterly (1990) 14(4), p. 82. 
Anexo III - Esclarecimentos da Funai sobre atuação do mercado voluntário de REDD em Terras Indígenas

A Fundação Nacional do Índio (Funai) informa que das mais de 30 etnias abordadas por empresas e/ou pessoas físicas para tratar de iniciativas de Redd e negociação de créditos de carbono no âmbito do mercado voluntário, nem todas fecharam contratos efetivamente, apesar de terem sido apresentados contratos e projetos.

O povo indígena Suruí, da Terra Indígena Sete de Setembro, não fechou nenhum contrato, eles tem conduzido o seu projeto de forma articulada com esta Fundação, e acatado as diversas recomendações da Funai quanto ao seu processo específico, inclusive com as certificações VCS (Voluntary Carbon Standard) e CCBA (Clima, Comunidade e Biodiversidade), recebendo padrão ouro. Tem havido por parte deles a devida cautela no processo, avaliando os riscos e as potencialidades do mercado voluntário e da assinatura de contratos nesse contexto. Há a expectativa de que a Associação do povo Suruí presente o projeto ao Fundo Amazônia e a Funai apóia essa iniciativa.

Quanto ao contrato de venda de créditos de carbono do complexo de terras indígenas Cinta Larga (Roosevelt, Aripuanã, Parque do Aripuanã e Serra Morena), com 2,7 milhões de hectares, a que a Funai teve acesso há aproximadamente um ano e meio, ele imobiliza toda a área e foi negociado por apenas alguns indivíduos da comunidade, não havendo consentimento de todos os indígenas. Desde que a Funai soube do contrato, várias providências foram tomadas, dentre elas a notificação à empresa responsável, realização de diversas reuniões informativas ao povo indígena Cinta Larga, comunicação oficial ao Ministério Público Federal para que acompanhe a questão, publicação orientadora sobre o assunto e comunicado oficial à Associação Cinta Larga esclarecendo a ilegalidade do contrato.

Assim como o caso citado acima, a maioria dos contratos a que a Funai teve acesso impedem os índios de executarem suas práticas tradicionais, como, por exemplo, plantação de roças e corte de árvores para subsistência sem prévia autorização da empresa. Além da previsão de contratos que perpassam por mais de uma geração e não prevêem cláusulas de rescisão contratual, caso haja algum prejuízo para a comunidade indígena.

A Funai, que tem como missão precípua a defesa dos direitos dos povos indígenas, é contra esses contratos. A Fundação tem informado às lideranças indígenas sobre a nulidade jurídica deles, tendo em vista que são terras da União e que a segurança jurídica exigida por esses contratos não pode ser dada pelos indígenas e sim pelo Estado brasileiro. Considerando, ainda, a falta de regulamentação no âmbito do Mecanismo Nacional de Redd, não existe qualquer validade nesses acordos. 
A Fundação defende a rápida regulamentação do Mecanismo Nacional de Redução por Desmatamento e Degradação Florestal (Redd), pois considera que a falta de regras claras é a origem das irregularidades contratuais observadas nessa questão. Considera, ainda, que esse Mecanismo deva prever um arranjo/metodologia que contemple a especificidade das terras indígenas - áreas protegidas que abrangem 23\% da Amazônia Legal.

Proteção territorial

As iniciativas da Funai em "estabelecer diretrizes e critérios a serem observados na concepção e execução das ações de proteção territorial e etnoambiental em terras indígenas" (Portaria no 1.682) não tem o objetivo de frear o assédio a contratos de Redd, tampouco de reduzir a incidência de iniciativas de contratos e projetos de Redd. A solução para essa questão é a regulamentação do Mecanismo Nacional.

A definição de diretrizes, pela Funai, para Proteção Territorial, objetiva regulamentar a participação de indígenas nas ações de vigilância territorial e ambiental, assim como nas atividades de localização e monitoramento de referências de povos indígenas isolados promovidas para proteção das terras que habitam e usufruem por direito, bem como de povos indígenas isolados.

Os projetos de vigilância, apoiados pela Funai, por meio do projeto de Proteção Territorial, estabelece algumas diretrizes e critérios a serem seguidos para a participação dos indígenas nas ações de vigilância ambiental e territorial. A indicação pelas suas comunidades, a necessidade de residir em território indígena e o não envolvimento em atividades ilícitas e/ou prejudiciais ao convívio em sua comunidade, são alguns exemplos.

A Funai destaca que o conhecimento dos povos indígenas sobre seus territórios é elemento fundamental das ações de vigilância, e a definição de diretrizes pela Fundação reconhece os serviços ambientais prestados pelas terras e povos indígenas. A participação indígena nas ações de proteção territorial e etnoambiental em suas próprias terras é uma expressão do exercício da autodeterminação e do direito de participação dos povos indígenas, conferindo eficiência a essas ações, assim como um estímulo ao protagonismo indígena na defesa de seus territórios.

Fonte: Notícia da FUNAI, divulgada no website do órgão em março de 2012. 
Anexo IV - Contrato entre Celestial Green Ventures e o Povo Munduruku

Contrato Numero: 473531-11-PV01

Data: 2011.06.01

Este contrato concede a empresa Celestial Verde Ventures PLC, empresa registrada com o numero 492008, com sede em 93 St. Stephen's Green.Dublin 2, Republica da Irlanda o titulo completo e de propriedade de quaisquer créditos de carbono obtidos no terreno de propriedade: Terra Indígena denominado Munduruku, por um período de 30 (trinta) anos.

Entre: Celestial Green ventures PLC, com sede em 93 St. Stephens Green Dublin 2, Republica da Irlanda, representado pelo seu diretor João Borges Andrade, com poderes para o ato.

E: Organização do povo Munduruku, com sede localizado no Município de Jacareacanga, Estado do Pará, representante da etnia denominado Índios Munduruku, proprietários da área de terra denominada: Terra Indígena Munduruku, demarcada administrativamente pelo decreto de 25 de Fevereiro de 2004,da Presidência da Republica, conforme documento junta.

Coordenadas: Conforme mapa e documento juntos a este contrato.

Área: Área total de 2.381.795,7765 ha (dois milhões trezentos e oitenta e um mil hectares setenta e sete ares e sessenta e cinco centiares).

Localização: Município de Jacareacanga, Estado do Pará. Brasil.

É assinado o presente contrato, registrado com o numero 473531-11-PV01.

Neste contrato, A organização do povo Indigena Munduruku é referido como "proprietário" e Celestial Green Venture PLC é referido como "empresa".

Duração do contrato: 30 anos (trinta anos).

Parágrafo 1

1.1 este contrato concede a empresa o direito de realizar todas as analises e estudos técnicos, incluindo acesso sem restrições a toda a área, aos seus agentes e 
representantes, com a finalidade de efetuarem a recolha de dados com o objetivo de se obter a máxima validação de Credito de Carbono da floresta.

1.2 Este contrato tem como objetivo criar as condições para a empresa Celestial Green venture PLC, utilizando todos e quaisquer métodos e ou metodologias ao seu alcance, proceder e conseguir a validação Internacional de Créditos de Carbono, por um período de 30(trinta) anos.

1.3 Os pagamentos previstos no documento Anexo 1 dão a empresa a totalidade dos direitos sobre os créditos de carbono obtidos, com quaisquer metodologias utilizadas e todos os direitos de quaisquer certificados ou benefícios que se venha a obter através da biodiversidade desta área, durante o período de contrato.

$1.4 \mathrm{O}$ proprietário concorda em fornecer a empresa todas as autorizações e documentos necessários, registros, autorizações, estatais e locais, aprovação e licenças, necessárias para a empresa realizar a sua atividade na área do projeto.

1.5 Se os créditos de carbono, por qualquer motivo forem inatingíveis nesta propriedade, então este contrato torna-se nulo e sem efeito.

1.6 Casos este contrato, em conformidade com 1.5 se venha a tornar nulo e sem efeito, as partes são responsáveis pelas suas próprias despesas incorridas e ou a incorrer.

\section{Parágrafo 2}

2.1 O proprietário concorda em não efetuar qualquer atividade ou alterações na propriedade, que possam de alguma forma afetar negativamente a concessão de créditos de carbono em qualquer das metodologias que a empresa se venha a comprometer para o período do contrato.

$2.2 \mathrm{O}$ proprietário compromete-se a manter a propriedade em conformidade com as metodologias estabelecidas pela empresa.

$2.3 \mathrm{O}$ proprietário compromete-se a cumprir todas as leis locais, estaduais e federais em relação a área do contrato.

\section{Parágrafo 3}

3.1 Sem o previa autorização por escrito da empresa, o proprietário compromete-se a não efetuar quaisquer obras na área do contrato, ou outra atividade que venha a alterar a qualidade de carbono captado ou que contribua de alguma forma para afetar negativamente a imagem da empresa e ou do projeto. 
3.2 Para a execução de obras ou intervenção que o proprietário pretenda efetuar na área do contrato, este deverá apresentar a empresa por escrito, plano pormenorizado da intervenção pretendida.

3.3 Sem a autorização da empresa, o proprietário compromete-se a não efetuar qualquer intervenção na área do projeto, nomeadamente: construções fixas ou temporárias corte e ou extração de madeira, queimadas, despejo de indígenas, construções de barragens ou retenção de cursos de água, mineração, agricultura, turismo, construção de estradas ou qualquer outra atividade que possam ter efeitos negativos sobre a metodologia a ser utilizada pela empresa, para validação do projeto.

\section{Parágrafo 4}

4.1 O proprietário, sem a previa autorização por escrito da empresa, deve abster-se de efetuar qualquer tipo de hipoteca, empréstimo, ou dar a área do projeto como garantia ou outro tipo de encargo, que de alguma forma abra a possibilidade de uma transferência da posse da terra durante o período acordado.

4.2 Qualquer acordo para empréstimo ou cadência da terra só pode ser efetuado com autorização da empresa e com a aceitação pelo credor das condições do presente contrato.

4.3 o proprietário fica proibido de vender, transferir ou doar a totalidade da terra ou parte, para terceiros sem o acordo prévio da empresa.

4.4 O proprietário fica proibido de entrar em qualquer tipo de contrato com terceiros, que possam de qualquer forma prejudicar a emissão de créditos de carbono no período acordado.

\section{Parágrafo 5}

$5.1 \mathrm{O}$ proprietário e a empresa comprometem-se a registrar este contrato e seguintes e respectivos aditivos, junto das autoridades competentes.

\section{Parágrafo 6}

6.1 O proprietário está proibido de entrar em qualquer tipo de acordo com qualquer empresa de terceiros que atuem no mercado de carbono, seus agentes ou representantes, durante a vigência deste contrato. 


\section{Parágrafo 7}

7.1 O proprietário compromete-se a cumpriri as normas éticas estabelecias pela empresa, ou seja, a manutenção das florestas, rios, flora e fauna, animais e povos Indígenas em seu estado natural e de acordo com as metodologias acordadas no projeto apresentado para validação pela empresa.

\section{Parágrafo 8}

8.1 Durante o período de vigência deste contrato, o proprietário mantém a posse da terra.

8.2 $\mathrm{Na}$ eventualidade do proprietário, pretender alienar a propriedade ou parte a terceiros, a empresa deverá ser informada por escrito dessa transação pendente e os potenciais novos proprietários devem ter conhecimento do presente contrato e comprometerem-se a respeitar os termos e condições presentes no mesmo.

$8.3 \mathrm{O}$ potencial novo proprietário só terá que obedecer a este contrato durante o período que permanecer no mesmo.

\section{Parágrafo 9}

9.1 A empresa compromete-se a utilizar os métodos e tecnológicos mais avançadas e modernas de verificação e analise da terra para alcançar o Maximo de créditos de carbono, em conformidade com as metodologias mais vantajosas a serem utilizadas na área do contrato.

\section{Parágrafo 10}

10.1 A empresa compromete-se a respeitar os termos e condições das metodologias validadas na área do contrato.

10.2 A empresa fará todo o possível, usando todos os métodos disponíveis, para proporcionar o máximo beneficio para todas as partes envolvidas nas áreas do contrato.

\section{Parágrafo 11}

11.1 A empresa compromete-se a elaborar os projetos técnicos, apresentá-los para validação e comercializar os créditos de carbono obtidos, coma a maior brevidade possível, usando todos os meios a sua disposição. 


\section{Parágrafo 12}

12.1 A empresa concorda, em junto ou através de seus agentes, manter o proprietário devidamente e atempadamente informado sobre os progressos alcançados na área do projeto.

\section{Parágrafo 13}

13.1 A empresa compromete-se a manter a área do presente contrato, em consonância com os princípios éticos e de acordo com as normas estabelecidas nas metodologias validadas.

\section{Parágrafo 14}

14.1 A empresa compromete-se a fazer todos os pagamentos ao proprietário dentro do período de tempo acordado, conforme estabelecido no anexo 1, aditivo ao presente contrato.

Parágrafo 15

15.1 Qualquer incumprimento das condições deste contrato pode deixar o proprietário(s) sujeito a processos judiciais.

\section{Parágrafo 16}

16.1 Este acordo e futuros termos aditivos ou alterações deverão ser autenticadas por um notário, devidamente e legalmente autorizado.

\section{Parágrafo 17}

17.1 Este acordo pode ser assinado por qualquer diretor de Celestial Green Venture PLC ou seu representante devidamente e especificamente autorizado para o efeito.

\section{Parágrafo 18}

18.1 Este acordo será regido e interpretado de acordo com as leis da Republica Federativa do Brasil. 
Parágrafo 19

19.1 A empresa não assume nenhuma responsabilidade por quaisquer impostos municipais, estaduais, federais ou outros direitos ou despesas efetuadas pelo proprietário e da responsabilidade deste.

19.2 Todos os pagamentos efetuados pela empresa ao proprietário devem ser considerados incluindo todos os impostos municipais, estaduais, federais e outros, taxas ou despesas efetuadas pelo proprietário.

19.3 A empresa não se responsabiliza por quaisquer passivos financeiros suportados pelo proprietário.

19.4 O proprietário declara que todos os documentos, certidões e registros, apresentados, são genuínos e verdadeiros e que os impostos e taxas municipais, estatais e outros referentes à propriedade do presente contrato, se encontram integralmente liquidados.

\section{A EMPRESA CELESTIAL GREEN VENTURES PLC}

\section{PROPRIETÁRIO ORGANIZAÇÃO DO POVO MUNDURUKU}

Toda a correspondência deve mencionar o numero deste contrato: 473531-11-PV01

Fonte: Agencia Pública de Notícias, disponível em: http://apublica.org/2012/03/terra-edos-indios-carbono-e-de-quem/ (último acesso em 05 de maio de 2016). 
Anexo V - Carta de Cuiaba sobre el cambio climático y los pueblos indígenas

Carta de Cuiaba sobre el cambio climático y los pueblos indígenas

El vigésimo dia del mes de noviembre del año dos mil ocho, en las dependências del Fondo para el Garden Hotel en la ciudad de Cuiaba, la reunión se celebró bajo el mandato de la COICA para sistematizar las propuestas de los pueblos indígenas de la cuenca del Amazonas a la Conferencia de las Partes $\mathrm{N}^{\circ}$ 14. Los dirigentes indígenas del Estado de Mato Grosso, con el apoyo de la Coordinación de Organizaciones Indígenas de la Amazonia Brasileña (COIAB) y de la Coordinación de Organizaciones Indígenas de la Cuenca Amazónica (COICA) sobre los Pueblos Indígenas, el Cambio Climático, Prevenibles por la deforestación (REDD) y Conservación de los Bosques. Los Pueblos Indígenas de la cuenca del Amazonas están en posesión de aproximadamente 220 milliones de hectáreas de bosques.

Asistir a esa sesión, 23 líderes indígenas de diferentes pueblos indígenas del Estado de Mato Grosso y la Amazonía por debajo de firmado. Las deliberaciones comenzaron con la limitación de los períodos de sesiones sobre el Cambio Climático, los aspectos científicos y técnicos y los impactos sobre los pueblos indígenas. Después de 3 días de debate, los líderes reunidos decidió adoptar la Convención de las Naciones Unidas sobre el Cambio Climático, COP14 en Poznan, Polonia que se celebrará entre los días 2 al 14 de diciembre de 2008, las siguientes demandas:

Intercambio de palabras "índios" por "pueblos indígenas"

1. Exigir que el nuevo régimen después de 2012, la Convención del Clima de respetar plenamente la Declaración de Derechos Indígenas de las Naciones Unidas.

2. Declaramos que estamos preocupados por los impactos del cambio climático en nuestras vidas, la cultura y el modo de vida de los Pueblos Indígenas de la Amazonia y otros biomas en todas las regiones del mundo. Exigimos que los países y las Naciones Unidas con urgencia priorizar el desarrollo de mecanismos de apoyo a las estratégias indígenas para adaptarse al cambio climático, 
reconocer y valorar los conocimientos tradicionales de los Pueblos Indígenas como una referencia clave para el seguimiento de nuevas estrategias de la humanidad para la adaptación al cambio climático.

3. Exigimos que todos los gobiernos a evaluar las consecuencias y reajustar los principales proyectos de desarrollo e infraestructura que pone en peligro los bosques y los pueblos indígenas y territorios de ultramar causando la deforestación de los bosques. Sin que la humanidad no puede contener el empeoramiento del cambio climático.

4. Que los gobiernos y toda la humanidad se reconocen en los servicios ambientales proporcionados por los Pueblos Indígenas para proteger, conservar y prevenir la deforestación en la selva amazónica y de otros biomas. Por lo tanto, demanda que el nuevo régimen de la Convención del Clima, los valores y benefícios inherentes a los Pueblos Indígenas de estos servicios a toda la humanidad en la forma en que desea recibir tales benefícios, dando prioridad a la elaboración y aplicación de mecanismo para premiar a los promueven la conservación de los bosques. Nos están sufriendo muchas presiones para producir ahora deforestando nuestra tierra. Sin el apoyo de proteger el bosque no se sabe cuánto tiempo vamos a resistir a la presión de deforestación. Sin los pueblos indígenas y los bosques el cambio climático se verá muy agravado y de la humanidad no sobreviverá.

5. Fortalecimiento de los mecanismos que REDD no puede ignorar la autonomia de los pueblos indígenas sobre sus territorios.

6. Nos preocupa que el post-2012 REDD régimen que se está debatiendo en las $\mathrm{CP}$ se utiliza para compensar a aquellos que siempre han limpiado nuestros bosques: los principales productores de soja, la ganadería y los biocarburantes y otros. Exigimos que la REDD y otros mecanismos de compensación para reducir las emisiones de carbono pagar priorizar y distribuir los benefícios a las personas que conservan el bosque y han resistido a la presión económica para deforestación.

7. Nuestra tierra es reconocida como más eficaz en la prevención de la deforestación de los bosques y almacenar carbono que las tierras privadas y las unidades de conservación. Por lo tanto, exigimos que el reconocimiento y la ejecución de nuestros derechos territoriales son una prioridade como estrategia 
importante para enfrentar el cambio climático y que todos los gobiernos dar de inmediato para garantizar los derechos territoriales de los Pueblos Indígenas de todas las regiones y territorios indígenas regresso tradicionales.

8. Exigimos que las Partes en la Convención del Clima el compromiso con el reconocimiento del derecho de los Pueblos Indígenas de carbono almacenado em sus territorios, ya que historicamente responsables de la protección y la gestión sostenible de sus bosques y tienen pleno derecho a uso exclusivo de los recursos naturales para sus Territorios.

9. La Convención del Clima y los gobiernos deben garantizar y proporcionar todas las condiciones para cualificada y la participación informada de los Pueblos Indígenas en el diseño del mecanismo de REDD y la aplicación de programas y proyectos para enfrentar al cambio climático.

10. Exigimos que cualquier estrategia de mercado de carbono, son de carácter voluntario o formal, respetando plenamente los derechos de los indígenas para garantizar los benefícios de créditos de carbono, como la legislación nacional y internacional que protege los derechos de los indígenas.

11. Exigimos que los recursos del Fondo, en la Amazonia, están destinados a los pueblos indígenas en proporción con el tamaño y el carbono almacenado en sus territorios. En lo que respecta a la Amazonia del Fondo, puesto en marcha por el gobierno brasileño en agosto de 2008, los dirigentes presentes tienen las siguientes recomendaciones: recomendación para eliminar aspectos específicos de la COIAB, pero mantener las observaciones sobre el fondo del Amazonas de Brasil como una referencia para el movimiento indígena internacional.

12. Lamentamos que no hubo participación indígena en las etapas iniciales de la formulación de la Amazonia.

13. El Fondo de Amazonia debería reconocer y apoyar las iniciativas de programas y proyectos que los índios ya están desarrolhadas, garantizar el derecho de los pueblos indígenas a decidir donde aplicar los recursos de la Amazonia para las tierras indígenas.

14. El Fondo de Amazonia debe apoyar proyectos destinados a fortalecer la capacidad institucional y técnica de las Organizaciones Indígenas COIAB y regionales y estatales a tomar una posición de apoyo a las comunidades indígenas en la construcción de proyectos para el Fondo de Amazonia. 
15. El Fondo de Amazonia debe apoyar el desarrollo y despliegue de diferentes mecanismos financieros específico para los Pueblos Indígenas. Este mecanismo debe servir para canalizar y hacer todos los recursos para los pueblos indígenas en realidad llegan a las comunidades indígenas de las iniciatvas. Los recursos del fondo de la Amazonia, para REDD y otros de pago por servicios ambientales, la indemnización y otros recursos ambientales deben aplicarse a través de mecanismos específicos.

\section{Los dirigentes aqui apoyo las decisiones adoptadas por COICA, que siguen a continuación:}

16. Afirmamos que los pueblos indígenas del Amazonas, son historicamente los tutores de sus territorios y sus bosques.

17. Exigimos que cualquier acción de REDD, debe proporcionar por la ley, benefícios directos a los pueblos indígenas amazónicos, de conformidad con la legislación nacional y las obligaciones internacionales aplicables.

18. Reforzar que no es correcto y práctico diseño de soluciones para el cambio climático sin la plena y efectiva participación de los pueblos indígenas.

19. Desde los pueblos indígenas tiene el derecho de uso exclusivo de sus territorios y bosques, las propuestas que no incluyen sus conocimientos y sus prioridades de trabajo no en la realidad.

20. Los defensores de las Partes en el restricto cumplimiento con las organizaciones indígenas de la cuenca amazónica del Amazonas, que por ley son los únicos órganos estatutários y interlocutores válidos en cualquier proceso de análisis, planificación, coordinación y ejecución y las políticas, programas y proyectos que afectan el ámbito territorial.

21. Buscar el amplio reconocimiento del papel de los pueblos indígenas y comunidades tradicionales en la defensa y la conservación de sus bosques y en la reducción de las emisiones de gases de efecto invernadero asociados con la deforestación tropical. 
Anexo VI - Posición Política de COICA sobre REDD+ (2010)

COORDINADORA DE LAS ORGANIZACIONES INDÍGENAS DE LA CUENCA AMAZONICA

\section{COICA}

\section{POSICION POLITICA DE COICA SOBRE REDD+}

Quito, Septiembre de 2010

\section{INTRODUCCION}

La extensión total de la cuenca amazónica oscila alrededor de $7.584 .421 \mathrm{~km} 21$. Comprende de Norte a Sur en el macizo de las Guyanas y Brasil, de Este a Oeste desde el océano atlántico hasta la cordillera de los andes. Brasil es el país que ocupa el porcentaje más alto de los bosques tropicales, seguido de otros países que ocupan proporciones menores, tales como son; Colombia, Ecuador, Perú, Bolivia, Venezuela, Surinam, Guyana Inglesa y Guyana Francesa. El sistema hidrográfico que circula como eje principal de distribución es el río Amazonas con 6,800 Km. de longitud2.

El carácter vital de la Cuenca Amazónica es ampliamente reconocido. Contiene la mayor cantidad de selva contigua sobre la tierra con una diversidad de hábitats, especies y pueblos sin igual, contribuye a mantener las funciones ecosistémicas del clima regional y global. La Amazonía alberga aproximadamente 349 Pueblos Indígenas (grupos étnicos) que hablan más de 300 idiomas, incluyendo algunos pueblos en situación de aislamiento voluntario.3 Casi la cuarta parte del área terrestre total de la Amazonía es parte de tierras, reservas y territorios indígenas comunitarios, sumado a ello áreas de uso tradicional.

La Amazonía cuenta actualmente con 92`808,200 millones de hectáreas transformadas 4 por la destrucción de hábitats, la interrupción y degradación de los flujos hidrológicos y la reducción de las poblaciones animales y vegetales que se encuentran bajo riesgo de extinción. Las principales amenazas directas son la expansión de la ganadería, y agricultura mecanizada, promovida por políticas de desarrollo regional e incentivos que fomentan un modelo neoliberal de crecimiento económico ajeno a la realidad de la región.

Los pueblos indígenas de la cuenca amazónica sabemos que estos modelos desarrollistas influyen al deterioro progresivo de nuestras formas de vida y lo más grave es que el asunto no queda ahí, sino, que el daño colateral que dichos modelos contribuyen con el incremento de emisión de dióxido de carbono en el espacio, agravan el estado climático del planeta, cuyo fenómeno es conocido con el nombre de Calentamiento Global.

El efecto inmediato del calentamiento global se llama "cambio climático". El cambio climático es un tema de debate a nivel internacional, cuyo proceso de discusión ha 
conducido a los gobernantes de los países industrializados y los negociadores multilaterales en plantear algunas alternativas de mitigación, entre los cuales está REDD (Reducción de Emisiones por Deforestación y Degradación) el cual va obteniendo diferentes variables de valoración como REDD+, REDD++.

1 Tratado de Cooperación Amazónica “Amazon sin Mitos”.

2 El País.com (16 de junio de 2007).

3 Tresierra 1999 as cited in USAID 2005.

4 Data from other authors collected in Nepstad et al. (2008)

REDD+ es un mecanismo y una política que va cobrando cuerpo a nivel internacional, principalmente por países industrializados que pretenden utilizar los bosques tropicales como sumideros de carbono a cambio de compensaciones económicas a los Estados posesionarios de dichos bosques. Frente a estos procesos a los pueblos indígenas nos toca la oportunidad de reafirmar lo que siempre hemos reclamado a lo largo de los tiempos; la defensa de nuestro territorio y todo lo que está adentro. Es importante y ya es tiempo que adoptemos a nivel de COICA las medidas que consideremos preventivas a los efectos del cambio climático con nuestras propias fortalezas a través del establecimiento colectivo de una posición POLITICA sobre cambio climático con mención a REDD+.

Este instrumento se desprende de la Posición de COICA sobre Cambio Climático (ver en el anexo), adoptado en Cochabamba y consideramos que debe constituirse en un referente regional cuya implementación recaerá en la competencia de las organizaciones nacionales miembros de COICA a través de diseño, promoción y desarrollo de ESTRATEGIAS propias de acuerdo a las realidades culturales de sus representados.

\section{CONTEXTO GLOBAL POR EL CUAL SE HACE NECESARIO ADOPTAR UNA POSICIÓN INDIGENA SOBRE MECANISMOS Y POLITICAS REDD+}

En el debate global sobre cambio climático no se vincula participación indígena, ni existe ninguna posibilidad de incidencia directa en este espacio, lo cual, nos expone con los siguientes riesgos de vulnerabilidad de nuestros derechos colectivos:

a. Que no se establezcan políticas claras que deben adoptar los Estados Nacionales a favor de los pueblos indígenas en momentos de implementar medidas de mitigación al cambio climático.

b. Algunas de las medidas de mitigación y adaptación planteadas por distintos actores y agentes que participan en el proceso multilateral de negociaciones de la CMNUCC, podrían generar mayores vulnerabilidades sobre nuestros territorios con directo impacto a los recursos de nuestra subsistencia. La promoción de monocultivos, biocombustibles, represas hidroeléctricas, semillas transgénicos, secuestro de carbono, políticas y mecanismos REDD+ y otros, son alguno de los indicadores del grave problema que 
tendremos en el futuro los pueblos indígenas si no tenemos una posición clara al respecto.

c. Que no existe ningún compromiso global de parte de los países industrializados responsables de la mayor cantidad de emisiones de dióxido de carbono (CO2) y otros gases tóxicos. Esto significa que no habrá medidas de desarrollo más amigable con la amazonia, más bien continuará el ritmo de deterioro constatado hasta ahora y si no tomamos medidas a nivel interno, nuestros territorios, el bosque la fauna y los recursos hídricos pronto se nos agotarán.

d. Que existe una creciente demanda de los países que tienen bosques tropicales para que los países industrializados compensen económicamente por la función que cumplen dichos bosques como sumideros de carbono, pero no se reconoce a nivel del contexto global, ni mucho menos a niveles nacionales que todo este potencial florístico es gracias al aporte milenario de los pueblos indígenas.

e. A pesar de ser nosotros los indígenas, quienes sufrimos desproporcionadamente los impactos actuales del cambio climático, los cuales se exacerban con la explotación desmesurada de los recursos naturales y la dinámica de degradación ambiental existentes en nuestros territorios; hemos sido marginados de participar en los procesos de definición y ejecución de las políticas, programas, planes y acciones encaminados a la mitigación de las causas del cambio climático y a la adaptación a sus efectos, tanto en el ámbito nacional como internacional5.

\section{CONOCIENDO EL CONTEXTO DE REDD+}

A nivel de los Estados Amazónicos aún no existe una estrategia sobre los mecanismos de participación de los pueblos indígenas en el desarrollo de los proyectos REDD+ (Reducción de Emisiones Derivada por Deforestación y Degradación), tampoco existe información clara de su concepto, ni metodología para su implementación. Esto por dos razones básicas:

a. Los proyectos REDD+ que funcionan actualmente en la región son a nivel de pilotos o experimentos, impulsados desde algunos países que cuentan con bosques tropicales, llámese Costa Rica, Bolivia (en alguna parte de la región oriente, promovido desde un sector privado), Brasil y las Guyanas, por citar algunos casos. Esto, con el interés que tienen algunos países industrializados de Europa de otorgar fondos a cambio de parar o disminuir la deforestación. Por ejemplo, el acuerdo en este contexto entre Brasil y Noruega, es un caso que ya se está dando antes del lanzamiento formal de las políticas a nivel de las Naciones Unidas.

b. La implementación formal de la política de REDD+ aún está en debate en la Convención Marco de las Naciones Unidas sobre el Cambio Climático (CMNUCC), cuya aplicación será después del año 2012. Posiblemente que la definición de su carácter vinculante y el concepto legal del mismo tendrá alguna similitud a las formas actuales de cómo se desarrollan los proyectos REDD+ pilotos o experimentales. Sin 
embargo, de cómo se está llevando el proceso sobre las políticas de cambio climático en medio de contradicciones y ambigüedades, el resultado final de la política de REDD+ a ser aplicado puede ser muy decepcionante para los pueblos indígenas en cuanto a sus derechos territoriales y los bosques que ocupa.

La existencia de estos dos procesos a la vez, confunde a los pueblos indígenas, porque se presta a muchas interpretaciones intuitivas que al final conducen a formas asimilativas del concepto impuesto.

Un problema no discutido a fondo ni socializado a tiempo, trae consecuencias severas sobre el medio ambiente y repercute de manera directa en la vida socio económico y cultural de los pueblos indígenas, como sucede con las actividades de hidrocarburos, concesiones forestales y proyectos de biocombustibles.

5 Declaración de los PPII de El Salvador, octubre de 2009.

\subsection{Ventajas y desventajas de REDD+6}

Ventajas:

1. Siempre y cuando los gobiernos decidan a favor, REDD+ podría contribuir a la consolidación de territorio de los pueblos indígenas y promoción de gobernanza local sobre el manejo de los recursos naturales de manera integral.

2. Si la reducción de la deforestación es instituida de manera consistente con los intereses indígenas, podría ayudar a la protección de la biodiversidad de plantas y animales, garantizar la protección de las tierras y medios de subsistencia indígenas.

3. Se fortalecería y se mejoraría la legislación a favor de los pueblos indígenas en aislamiento voluntario y aquellos que se encuentran en situación de contacto inicial.

4. REDD+ podría contribuir al fortalecimiento y formalización del régimen forestal internacional y que esto podría representar "una oportunidad para hacer presión para la obtención de reformas políticas y legales respecto a los bosques y a los derechos de los pueblos indígenas".

5. REDD+ podría generar beneficios económicos a las comunidades y contribuiría en el mejoramiento de sistemas actuales de uso del bosque a través de la apropiación de tecnologías innovadoras de manejo diversificado de los demás recursos naturales.

Desventajas:

1. Varios representantes de pueblos indígenas y otras organizaciones involucradas en el tema de cambio climático han expresado sus preocupaciones respecto a los posibles impactos negativos. Por ejemplo, si a los bosques se les atribuye un valor monetario, bajo un esquema REDD+, muchos temen que - en lugares donde los derechos de propiedad territorial no son claros y la toma de decisión se lleva a cabo de manera autoritaria - nuevos conflictos surgirán entre las comunidades indígenas y locales, así 
como entre ellas y el Estado. Por tanto, los mecanismos REDD+ podrían excluir a las poblaciones locales de los procesos de implementación así como de la repartición de beneficios, y posiblemente hasta expulsarlos de sus propios territorios: "El incremento del valor monetario atribuido a los actuales recursos de los bosques en pie así como a aquellos en crecimiento, abre puertas a la corrupción en países dónde ésta abunda en el sector forestal.

2. También preocupa que el sistema REDD+ esté siendo deliberadamente diseñado para excluir los derechos de los pueblos indígenas. Por ahora nada indica en forma clara y explícita que las comunidades o los PPII vayan a verse beneficiados. Además los pueblos indígenas y otros grupos, como las organizaciones de mujeres y los movimientos campesinos, han quedado casi totalmente excluidos del desarrollo del sistema. Si esta tendencia se mantiene, dichos grupos no tendrán oportunidad alguna de influir sobre los acuerdos ni de participar en pie de igualdad en los proyectos REDD+.

3. Probable captura y acaparamiento de los recursos financieros internacionales disponibles para la ejecución del mecanismo de REDD+ por parte de las grandes

6 Manual informativo de COICA sobre Cambio Climático y REDD.

compañías y de las élites locales y nacionales, excluyendo a los pueblos indígenas y a las comunidades locales del papel central que deben tener si el objetivo es lograr de manera exitosa el fin de la deforestación.

4. Con este conocimiento, los PPII de la Amazonía peruana, definimos nuestros propios lineamientos políticos, de acuerdo a nuestra forma de pensar y concebir sobre lo que promete ser REDD+ en el presente y futuro.

IV. BASE DE DERECHOS A TRAVES DEL CUAL SE PROPONE LA PRESENTE POSICION RESPECTO A REDD+

Convenio 169 de la OIT:

Art. 4 - 1 y 2; Art. 5 - a; Art. 6, 1-a, b, c. 2; Art. 7- 1; Art. 13 - 1, 2; Art. 14 - 1, 2, 3; Art. 15 - 1; Art. 17 - 3.

Declaración de Naciones Unidas sobre los Derechos de los PPII:

Art. 3, 4, 18, 19; Art. 20 -1; Art. 25; Art. 26 - 1, 2, 3; Art. 27; Art. 29 - 1; Art. 31 -1; Art. $32-1$; Art. $36-1,2$;

Artículo 27 de la Convención de Viena sobre el Derecho de los Tratados, suscrita en 1969 y vigente desde 1980: (El derecho interno de los Estados, las reglas de las organizaciones internacionales y la observancia de los tratados)

1. Un Estado parte en un tratado no podrá invocar las disposiciones de su derecho interno como justificación del incumplimiento del tratado. 


\section{LINEAMIENTOS POLITICOS DE LOS PUEBLOS INDIGENAS AMAZONICOS RESPECTO A LOS MECANISMOS DE REDD+}

LINEAMIENTO PRIMERO. La política de REDD+ y sus mecanismos, así como los proyectos de iniciativa REDD+, serán adoptados bajo el principio de acción colectiva y desde la cosmovisión de los PPII, para mitigar las causas del calentamiento global, provocado por intervención humana (antropogénica), teniendo como elementos vitales a proteger:

1. El suelo

2. El bosque

3. El oxigeno

4. El agua

LINEAMIENTO SEGUNDO. Para proteger el suelo, el bosque, el oxígeno y el agua, utilizaremos los conocimientos y sabidurías que nuestros ancestros nos legaron y para hacer viable estas prácticas, consideramos esenciales desarrollar los derechos a:

1. La consolidación jurídica de territorios indígenas.

2. Ordenamiento territorial y zonificación económica y ecológica de espacios de dominio indígena.

3. Fortalecer las formas de gobernabilidad en territorios de los pueblos indígenas. En nuestros territorios y en los aspectos sociales, culturales, espirituales, económicos y políticos internos que inciden de manera directa con las formas de uso de los recursos naturales y protección de la diversidad biológica de la amazonia.

LINEAMIENTO TERCERO. Para garantizar que ninguna actividad económica con carácter extractivo debe imponerse y desarrollarse en territorios indígenas a nombre de la iniciativa REDD+, adoptaremos las siguientes medidas:

1. No aceptación de ninguna figura que justifique proyectos de monocultivos en territorios indígenas sean de ocupación legal y de uso tradicional.

2. No aceptación de intermediarios de carbono a costa de bosques al interior de territorios indígenas legalmente reconocidos, ni en espacios de usos tradicionales.

3. No aceptación de concesión de bosques superpuestos en territorios indígenas bajo ninguna figura de mercado de carbono o todo proyecto privado o estatal que pretenda desarrollar el rubro de carbono a costa de bosques en territorios indígenas.

LINEAMIENTO CUARTO. Cualquier actividad de iniciativa REDD+ en territorio de los pueblos, nacionalidades y comunidades indígenas, deberá cumplir los siguientes procedimientos y consultas: 
1. Los Estados Nacionales deben tener en cuenta los procedimientos de consulta previa, libre e informada para el consentimiento de los pueblos indígenas de acuerdo a lo establecido en el Convenio 169 de la OIT.

2. Canalizar las consultas a los pueblos y nacionalidades indígenas respetando el sistema y estructuras de representación de las organizaciones indígenas en cada país, así como garantizar la presencia de sus líderes, lideresas y dirigentes.

3. Las consultas a los pueblos y nacionalidades indígenas deberán realizarse sin intermediación de terceros, con materiales de información traducidos en idioma del pueblo o nacionalidad sujeto de consulta, así como garantizar la presencia de traductores indígenas.

LINEAMIENTO QUINTO. Siempre y cuando sea de iniciativa indígena desarrollar alguna actividad de servicios ambientales; por auspicio de iniciativas REDD+ o por otros mecanismos en sus territorios, se deberá tener en cuenta crear las siguientes condiciones:

1. Contar con recursos humanos y técnicos propios mediante capacitaciones en sistemas y metodologías de medición de carbono y de los mecanismos de beneficios por servicios y bienes ambientales.

2. Haber realizado Zonificación Económica y Ecológica del territorio indígena y fijado áreas de manejo de bosques.

3. Levantamiento autónomo de línea de base del potencial de carbono almacenado en los bosques de dominio indígena.

4. Contar con organismos aliados y expertos en temas de asesoría técnica y científica sobre la materia para no ser sorprendido ni caer en engaños.

5. Informar, capacitar sobre las ventajas y desventajas que ofrece los mecanismos de compensación por servicios y bines ambientales.

6. Promover pasantías de intercambio de experiencias con otros pueblos de la amazonia respecto al ordenamiento territorial y zonificación económica y ecológica autónoma de territorios indígenas.

7. La distribución de beneficios debe ser de acuerdo a las necesidades propias de los pueblos indígenas. Por ejemplo; becas para estudios, transferencias de tecnologías apropiadas en alternativas energéticas, transformación y certificación de productos, seguridad de conocimientos indígenas, etc.

8. Las negociaciones para la prestación de servicios y bienes ambientales, serán de manera directa sin intermediarios. 
LINEAMIENTO SEXTO. Será rechazado cualquier actividad de iniciativa REDD+ o de cualquier mecanismo que tenga como práctica:

1. Subcontratar a las comunidades, pueblos y nacionalidades con beneficios en desventaja.

2. Practicas de enganche para endeudar a las comunidades.

3. Apropiarse de títulos de propiedad de las comunidades, de los resguardos territoriales, circunscripciones territoriales o de tierras comunitarias de origen, etc.

4. Practicas de intermediación de autoridades comunitarios por aprovechamiento individual en complicidad con intermediarios sin información transparente a la población.

5. Compra y venta de territorios indígenas.

6. Fraccionamiento de territorios indígena por parcelas individuales.

VI. ESTRATEGIAS DE INTERVENCION SOBRE DESARROLLO DE LAS POLITICAS Y MECANISMOS REDD+ EN LA AMAZONIA

Estrategia informativa:

1. Necesitamos contar con manuales informativos sobre cambio climático y REDD+, a fin de conocer los aspectos técnicos que sustentan el incremento del calentamiento global y el propósito real que persiguen los países respecto al bosque y su aporte a la humanidad.

2. Necesitamos estar capacitados con experiencias sobre REDD+ en distintas partes de la amazonia y regiones intercontinentales, a fin de conocer los beneficios que ofrecen

los proyectos REDD+ y contribuir con esta información en la toma de decisiones a favor de nuestros bosques y territorios.

3. Información masiva de los alcances de iniciativas REDD+ en las comunidades indígenas para evitar que las autoridades locales sean sorprendidos con informaciones nada exactas que al fin incidan de manera negativa sobre sus territorios comunales.

4. Trabajar con los medios de información escrita y sobre todo radial para llegar en la población indígena y la sociedad civil en general con un mensaje entendible y reflexivo sobre la problemática climática e iniciativas REDD+, citando casos nacionales e internacionales y experiencias concretas.

5. Capacitación de capacitadores indígenas y los representantes de las organizaciones miembros.

6. Las organizaciones nacionales deben tener una lista de promotores indígenas capacitados y de aliados en coordinación estrecha con organizaciones indígenas de sus 
representados, a la vez contar con un sistema y metodología de llegada a las comunidades con un solo mensaje y no confundir a la población con diferentes posiciones.

7. Las organizaciones nacionales deben resumir el manual informativo sobre cambio climático y REDD+ de COICA con un lenguaje más entendible para las poblaciones locales con traducciones correspondientes, incluyendo análisis crítico de temas técnicos y políticos, según la realidad de cada país y el estado de sus avances en la materia.

8. Las organizaciones nacionales deben crear espacios informativos dentro de sus páginas web sobre temas del clima y REDD+, así mismo participar con sus aportes e ideas en diversos medios de iniciativa civil, a fin de contribuir que la mayoría de la población se informe y tome sus mejores decisiones para incidir en las políticas nacionales.

9. Producir fotos y videos sobre cambio climático y REDD+ para difundir en las comunidades. El mensaje debe tener contenidos claros que responda intereses colectivos.

10. Introducir el tema de cambio climático y REDD+ en el sistema curricular educativo y promover su aplicación en todas las escuelas en diferentes niveles de formación.

11. Incidir en los mecanismos de información de los Estados para que los mensajes sean coherentes con la expectativa de los pueblos indígenas y la sociedad civil en general.

12. Redoblar los procesos de incidencia a nivel internacional sobre la posición indígena en el tema de cambio climático y REDD+ con argumentos y ejemplos concretos. Para ello, hay que tener insumos, casos y materiales informativos debidamente sistematizados.

Estrategia normativa:

1. Proponer y generar normativas a nivel de gobiernos locales y otras instancias gubernamentales de niveles intermedios en lo relacionado al ordenamiento territorial y zonificación económica y ecológica autónoma de territorios indígenas.

2. Generar propuesta de normativas locales y otras instancias gubernamentales de niveles intermedios sobre los mecanismos de gobernanza autónoma de los pueblos indígenas en sus territorios en lo relacionado al manejo de los bosques ubicado en sus territorios legales y usos ancestrales.

3. Elaboración de metodologías y guías prácticas de zonificación económica y ecológica autónoma de territorios indígenas con validación de autoridades del Estado de cada país.

4. Generar propuestas de normativa a nivel de COICA (regional) para lograr legislaciones que establezcan políticas y mecanismos claros sobre desarrollo de iniciativa REDD+ y gestión integrada de territorios indígenas en cada uno de los 
Estados, incluyendo propuestas que garanticen la intangibilidad de territorios de los pueblos indígenas en aislamiento voluntario.

5. Elaborar criterios, pasos y procedimientos mínimos que se requieren para una efectiva consulta a los pueblos indígenas y proponérsela a los Estados para su consideración en acción conjunta con las organizaciones indígenas nacionales.

6. Trabajar temas de gobernanza en un concepto más amplio del mecanismo que integre la visión indígena del territorio.

7. Identificar casos concretos de iniciativas REDD+; análisis de escenarios, limitaciones de mecanismos y rescatar modelos positivos para réplica en los de mas países y mejoramiento de las normativas nacionales.

8. Alianza con varios organismos a fines a la conservación de la Amazonía y establecer con ellos principios de relación y cooperación institucional a fin de promover normativas que favorezcan la gestión integrada de territorios indígenas.

9. Incidir ante los estados para que la Declaración de las Naciones Unidas sobre los derechos de los pueblos indígenas sea tratada e implementada en cada uno de los países suscriptores y promover la creación de mecanismos de veeduría para el cumplimiento de los tratados internacionales, incluyendo la buena aplicabilidad del Convenio 169 de la OIT.

10. Los líderes nacionales, sub nacionales y locales necesitan ser capacitados e informados sobre procesos internacionales de cambio climático para que puedan responder con conocimiento de causa en las consultas que los estados organizan.

Estrategia organizativa:

1. Las organizaciones indígenas nacionales deben elaborar estrategias locales de intervención sobre políticas y mecanismos REDD+ y capacitar de dichas estrategias a líderes y dirigentes indígenas, junto con manuales de cambio climático y REDD+.

2. Los pueblos indígenas deben tener una hoja de ruta de hacia dónde debe encaminar su participación en el desarrollo de la iniciativa REDD+.

3. Reafirmar y reconocer la representación indígena por niveles estructurales establecidos: comunal, zonal, regional - departamental y nacional (dependiendo de

la realidad organizativa de los pueblos indígenas de cada país) y exigir que toda intervención externa debe respetar dichas estructuras. Esto con la finalidad de mantener la unidad y fortaleza institucional.

4. Identificación e inventario de las comunidades, pueblos y nacionalidades que están desarrollando los proyectos de iniciativa REDD+ u otros mecanismos. 
5. Establecer observatorios de REDD+ a través del cual implementar Plan de Monitoreo de proyectos de iniciativa REDD+ y otros mecanismos donde estos funcionen sea en forma de pilotos o de manera formal en los pueblos indígenas.

6. Tener formularios básicos de las preguntas claves que deben tener las autoridades locales en cuanto reciban ofertas de apoyo de los proyectos de iniciativa REDD+, con criterios de coordinación que dichas autoridades deben mantener con sus organizaciones representativas.

7. Establecer mecanismos nacionales de soporte técnico y asesoría oportuna a las comunidades y organizaciones indígenas a fin de evitar disparidad de acciones que acaben debilitando la estrategia de gestión integrada de territorios indígenas.

8. Establecer principios y criterios mínimos para desarrollar cualquier iniciativa de proyecto REDD+ con terceros. Estos principios deben desprenderse de visión y posición regional acordada a nivel de COICA.

Estrategia de incidencia:

1. COICA sistematiza la demanda indígena y disemina tales demandas a nivel de incidencia internacional ante organismos como el Banco Mundial, BID, así como en los encuentros internacionales previos al desarrollo de las Conferencias de las Partes (COPs) y en reuniones de grupos de trabajo técnicos de negociaciones sobre cambio climático e iniciativas REDD+.

2. COICA promueve que en los eventos internacionales participen los representantes de las organizaciones indígenas de nivel nacional.

3. Las organizaciones indígenas nacionales, junto con sus organizaciones indígenas miembros deben diseminar las informaciones sobre cambio climático y REDD+ que llegan del exterior para mantener informado a la población, así mismo estar atentos de cualquier atropello y vulneración de los derechos colectivos de los PPII que puedan existir en sus países.

4. Reforzar los mecanismos de relación entre COICA y las OOII de niveles nacionales para retroalimentar y suministrarse de informaciones sobre cambio climático y REDD+ a fin de fortalecer los mecanismos de incidencias internacionales y nacionales.

5. Identificar información de casos claves que puedan ser considerados como amenazas y socializar con organizaciones indígenas miembros para reforzar las acciones de incidencia al interior de los Estados Nacionales, organismos internacionales y bilaterales con participación activa de las organizaciones indígenas representativas desde lo local, sub nacional, nacional y regional.

6. La estrategia de incidencia debe estar orientado a una visión de defensa global de territorios indígenas, involucrando otras amenazas existentes como las represas, hidrocarburos, minería, monocultivos, etc que no necesariamente surge de REDD+, 
pero que en nombre de mitigación al cambio climático, aparecen otros proyectos con mayor impacto social, cultural y ambiental.

7. COICA debe estar muy claro de las políticas de FONDOAMAZONIA y otros organismos similares e informar de manera oportuna a sus organizaciones miembros de la existencia de esta instancia y sus principales fines, asumiendo un rol más activo de incidencia para que las oportunidades de REDD+ respondan la gestión integrada de territorios indígenas en el marco de visión compartida de conservación.

8. Transparencia en la información. Que toda la información que llegue a COICA o que sea preparada por COICA y sus organizaciones miembros llegue en los idiomas de cada una de las organizaciones nacionales.

9. Elaboración de mapa de impactos sociales, culturales y ambientales de los pueblos indígenas para reforzar las acciones de incidencia a nivel internacional y a nivel interno.

Estrategia territorial:

1. Creación de unidades territoriales por pueblos indígenas a fin de realizar los trabajos de zonificación económica y ecológica autónoma de territorios indígenas.

2. Continuar con el saneamiento legal de territorios indígenas.

3. Auto demarcación de territorios ancestrales por pueblos indígenas a fin de garantizar la continuidad del eco sistema amazónico y promover el bienestar de dichos pueblos a través de gestión integrada de territorios indígenas.

4. Ejercer prácticas de gobernanza autónoma en territorios indígenas en salvaguarda del bosque, el suelo, el gua y el aire. Los pueblos indígenas tienen fortaleza de sus conocimientos para hacer de estos saberes como un potencial efectivo en las acciones de mitigación al cambio climático. Cuanto más reivindicación histórica de sus territorios ancestrales, mayor captura de carbono y reservas del oxigeno para el mundo. 
Anexo VII - Declaração de Albuquerque

The Albuquerque Declaration

November 1, 1998

The Indigenous Peoples of the Turtle Island sent over 180 delegates to Albuquerque, New Mexico to share ideas on the impact of climate change and climate variability on Indigenous Peoples and all life on Mother Earth. The Indigenous Peoples worked together to offer solutions to reduce global warming and contribute to the restoration of sustainable economies on Native homelands for our future generations. On behalf of the delegates at this Albuquerque gathering, we are sending this ALBUQUERQUE DECLARATION throughout the world for global dissemination. If we continue this path of unsustainable developments, we may not have a future for our children.

Oren Lyons, Faithkeeper, Chief, Onondaga Nation

Tom "Mato Awanyankapi" Goldtooth, National Spokesperson, Indigenous

Environmental Network (IEN)

Patrick Spears, President, and Bob Gough, Secretary, Intertribal Council on Utility

Policy (ICOUP)

Jackie Warledo, Field Representative, International Indian Treaty Council (IITC)

THE ALBUQUERQUE DECLARATION

from the "CIRCLES OF WISDOM"

NATIVE PEOPLES / NATIVE HOMELANDS

CLIMATE CHANGE WORKSHOP and SUMMIT

November 1, 1998, Albuquerque, New Mexico

\section{PREAMBLE}

As Indigenous Peoples, we begin each day with a prayer, bringing our minds together in thanks for every part of the natural world. We are grateful that each part of our natural world continues to fulfill the responsibilities that have been set for it by our Creator, in an unbreakable relationship to each other. As the roles and responsibilities are fulfilled, we are allowed to live our lives in peace. We are grateful for the natural order put in place and regulated by natural laws.

Most of our ceremonies are about giving thanks, at the right time and in the right way. They are what was given to us, what makes us who we are. They enable us to speak about life itself. Maintaining our ceremonies is an important part of our life. There is nothing more important than preserving life, celebrating life, and that is what the ceremonies do. Our instruction tells us that we are to maintain our ceremonies, however 
few of us there are, so that we can fulfill the spiritual responsibilities given to us by the Creator.

The balance of men and women is the leading principle of our wisdom. This balance is the creative principle of Father Sky and Mother Earth that fosters life. In our traditions, it is women who carry the seeds, both of our own future generations and of the plant life. It is women who plant and tend the gardens, and women who bear and raise the children. The women remind us of our connection to the earth, for it is from the earth that life comes.

We draw no line between what is political and what is spiritual. Our leaders are also our spiritual leaders. In making any law, our leaders must consider three things: the effect of their decisions on peace; the effect on the natural order and law; and the effect on future generations. The natural order and laws are self-evident and do not need scientific proof. We believe that all lawmakers should be required to think this way, that all constitutions should contain these principles.

Our prophecies and teachings tell us that life on earth is in danger of coming to an end. We have accepted the responsibility designated by our prophecies to tell the world that we must live in peace and harmony and ensure balance with the rest of Creation. The destruction of the rest of Creation must not be allowed to continue, for if it does, Mother Earth will react in such a way that almost all people will suffer the end of life as we know it.

A growing body of western scientific evidence now suggests what Indigenous Peoples have expressed for a long time: life as we know it is in danger. We can no longer afford to ignore the consequences of this evidence. We must learn to live with this shadow, and always strive towards the light that will restore the natural order. How western science and technology is being used needs to be examined in order for Mother Earth to sustain life.

Our Peoples and lands are a scattering of islands within a sea of our neighbors, the richest material nations in the world. The world is beginning to recognize that today's market driven economies are not sustainable and place in jeopardy the existence of future generations.

It is upsetting the natural order and laws created for all our benefit. The continued extraction and destruction of natural resources is unsustainable.

There is a direct relationship between the denial of Indigenous Peoples land and water rights, along with the appropriation without consent of Indigenous Peoples' natural resources, and the causes of global climate change today. Examples include 
deforestation, contamination of land and water by pesticides and industrial waste, toxic and radioactive poisoning, military and mining impacts.

The four elements of fire, water, earth and air sustain all life. These elements of life are being destroyed and misused by the modern world. Fire gives life and understanding, but is being disrespected by technology of the industrialized world that allows it to take life such as the fire in the coal-fired powered plants, the toxic waste incinerators, the fossil-fuel combustion engine and other polluting technologies that add to greenhouse gases. Coal extraction from sacred earth is being used to fuel the greenhouse gases that are causing global climate warming.

Because of our relationship with our lands, waters and natural surroundings which has sustained us since time immemorial, we carry the knowledge and ideas that the world needs today. We know how to live with this land: we have done so for thousands of years. We are a powerful spiritual people. It is this spiritual connection to Mother Earth, Father Sky, and all Creation that is lacking in the rest of the world.

Our extended family includes our Mother Earth, Father Sky, and our brothers and sisters, the animal and plant life. We must speak for the plants, for the animals, for the rest of Creation. It is our responsibility, given to us by our Creator, to speak on their behalf to the rest of the world.

For the future of all the children, for the future of Mother Earth and Father Sky, we call upon the leaders of the world, at all levels of governments, to accept responsibility for the welfare of future generations. Their decisions must reflect their consciousness of this responsibility and they must act on it. We demand a place at the table in discussions that involve and effect our future and the natural order and natural laws that govern us.

\section{THEREFORE}

We, the participants in the "Circles of Wisdom" Native Peoples / Native Homelands Climate Change Workshop, held in Albuquerque, New Mexico of the United States, in the traditional territory of the Pueblo Peoples, express profound concern for the wellbeing of our sacred Mother Earth and Father Sky and the potential consequences of climate imbalance for our Indigenous Peoples and the significance of these consequences for our communities, our environment, our economies, our culture and our relationships to the natural order and laws.

Indigenous prophecy now meets scientific prediction. What we have known and believed, you also now know: The Earth is out of balance. The plants are disappearing, the animals are dying, and the very weather - rain, wind, fire itself - reacts against the actions of the human being. For the future of the children, for the health of our Mother Earth, Father Sky, and rest of Creation, we call upon the people of the world to hold 
your leaders accountable.

We submit this declaration to the Fourth Conference of the Parties (COP4) to the United Nations Framework Convention on Climate Change (FCCC) being held in Buenos Aires, Argentina, November 2-13, 1998. We wish to add our voices to ongoing global discussions regarding the impact of climate imbalance on forests, oceans, plants, animals, fish, humans and biodiversity.

\section{PRINCIPLES}

The following principles are self-evident and guide our beliefs and actions.

Mother Earth, Father Sky, and all of Creation, from microorganisms to human, plant, trees, fish, bird, and animal relatives are part of the natural order and regulated by natural laws. Each has a unique role and is a critical part of the whole that is Creation. Each is sacred, respected, and a unique living being with its own right to survive, and each plays an essential role in the survival and health of the natural world.

As sovereign Peoples and Nations, we have an inherent right to self-determination, protected through inherent rights and upheld through treaties and other binding agreements. As Indigenous Peoples, our consent and approval are necessary in all negotiations and activities that have direct and indirect impact on our lands, ecosystems, waters, other natural resources and our human bodies.

Human beings are part of the natural order. Our role and responsibility, as human beings, is to live peacefully and in a harmonious balance with all life. Our cultures are based on this harmony, peace and ecological balance which ensures long term sustainability for future generations. This concept of sustainability must be the basis of the decisions and negotiations underway on national and international levels.

The Creator has entrusted us a sacred responsibility to protect and care for the land and all of life, as well as to safeguard its well-being for future generations to come.

Indigenous Peoples have the right and responsibility to control access to our traditional knowledge, innovations and practices, which constitute the basis for the maintenance of our lifestyles and future [The Draft Declaration of the Rights of Indigenous Peoples];

\section{CONCLUSIONS}

Indigenous Peoples of North America were invited by neither the United States nor Canada to participate in the negotiations of the United Nations Convention on Climate Change. 
In June 1997, more than 2,000 U.S. scientists, from over 150 countries, including Nobel Laureates, signed the Scientists Statement on Global Climate Disruption which reads, in part, the "accumulation of greenhouses gases commits the sacred earth irreversibly to further global climate change and consequent ecological, economic, social and spiritual disruption" (Intergovernmental Panel on Climate Change, December 1995). Climate imbalance will cause the greatest suffering to the Indigenous peoples and most pristine ecosystems globally.

The migration of Persistent Organic Pollutants (POPs) through the air and water pathways continues from warmer southern climates to the colder climates of the Great Lakes and Arctic climates of North America and the Arctic Circle. Increased temperatures and persistent organic pollutants (POPs) disproportionately impact indigenous Peoples, through their food web systems, causing health and ecosystem impacts.

Within the next 100 years, temperatures over land areas of North America, Europe and Northern Asia will increase as much as 5 to 15 degrees Fahrenheit over today's normal temperatures, well in excess of the global average (IPCC Report 1998). This increase in temperature will cause the sea level to rise (5-25 feet over the next 500 years), drying out North America's soil moisture (20-50\%), and result in major increases in the summer heat index (10-25 degrees F).

The burning of oil, gas, and coal ("fossil fuels") is the primary source of human-induced climate change. The increasing demand and use of fossil fuels continues to have adverse impacts on natural forests. Natural forests are critical parts of the ecosystems that maintain global climate stability. The continued large-scale taking of fossil fuels results in numerous impacts on these vital areas through deforestation and pollution from drilling operations and ultimately forest degradation from the global climate imbalance. The mining and drilling for coal, oil, and gas, as well as other mineral extractions, results in substantial local environmental consequences, including severe degradation of air, forests, rivers, oceans and farmlands.

Cultural impacts, forced removal, land appropriation, destruction of sacred and historical significant areas, breakdown of Indigenous social systems, and violence against women and children are too often the outcomes of fossil fuel development on Indigenous Peoples. Fossil fuel extraction areas are home to some of Mother Earth's last and most vulnerable Indigenous populations, resulting in accelerated losses of biodiversity, traditional knowledge, and ultimately in ethnocide and genocide.

\section{ACTIONS}


We request that the potential consequences of climate imbalance for Indigenous Peoples and our environments, economies, culture, place and role in the natural order be addressed by:

- Establishing and funding an Inter-sessional Open-ended Working Group for Indigenous Peoples within the Conference of the Parties (COPs) of the UN Framework Convention on Climate Change (FCCC);

- Provisions for case studies be established within the framework of UNFCCC that would allow for assessing how climate changes effect different regions of Indigenous Peoples and local communities; assessing climate changes on flora and fauna, freshwater and oceans, forestry, traditional agricultural practices, medicinal plants and other biodiversity that impact subsistence and land-based cultures of Indigenous Peoples; and other case studies that would provide a clearer understanding of all effects and impacts of climate change and warming upon Indigenous Peoples and local communities;

- Indigenous Peoples have the right, responsibility and expertise to participate as equal partners at every level of decision-making including needs assessments, case studies, within national and international policy-making activities concerning climate change impacts, causes and solutions;

- Within the UNFCCC, establish protocols that would actively promote international energy efficient and sustainable forms of development, including the widespread use of appropriately scaled solar energy and renewable energy technologies as well as sustainable agricultural and forestry practice models;

- Mandating a moratorium on new exploration and projects for extraction for fossil fuel reserves in pristine areas. Exploration and development in the traditional territories of Indigenous Peoples of the world must be done with the full consent of Indigenous Peoples, respecting their right to decline a project that may adversely impact them;

- Imposing a legally binding obligation to restore all areas already affected by oil, gas, and coal exploration and exploitation by the corporations or public entities that are responsible. This restoration must be done such that Indigenous Peoples can continue traditional uses of their lands.

This is a partial list of additional Indigenous and non-Indigenous groups signing in support of the Declaration. The following Indigenous Peoples and Nations attended this Albuquerque Workshop Summit and fully endorse this declaration: 
Haudenosaunee Environmental Task Force Mohawk, Oneida, Onondaga, Cayuga, Seneca and Tuscarora

Native Coalition for Cultural Restoration of Mount Shasta and Medicine

Lake Highlands Defense

Columbia River Alliance for Economic and Environmental Education

International Movement Against All Forms of Discrimination and Racism

International Indian Treaty Council

Intertribal Council on Utility Policy

Native American Council of New York City

Seventh Generation Fund

Roundtable of Institutions of People of Color

Sapa Dawn Center

Dine' Citizens Against Ruining the Environment (CARE)

Anishinabe Niijii

North American Indigenous Peoples Biodiversity Project

Gwiichin Steering Committee

Alaska Council of Indigenous Environmental Network

Eastern Cherokee Defense League

Great Lakes Regional Indigenous Environmental Network

White Clay Society of Gros Ventre

Oklahoma Regional Indigenous Environmental Network

Shundahai Network

American Indian Chamber of Commerce of New Mexico

American Indian Law Alliance

Traditional and Spiritual Leaders:

Oren Lyons, Onondaga; Kendall Rice, Potawatomi; Arvol Looking Horse, Lakota; Marvin Stevens, Kickapoo; Tom Stillday Jr., Red Lake Ojibway; Johnny Jackson, Yakama Cascade Band; Corbin Harney, Western Shoshone; Jake Swamp, Mohawk; Albert Yazzie, Navajo; Richard Dalton Sr, Tlingit

Individuals:This is a partial list.

Tonya Goubella Frichuer, Onondaga; Chuck Crowe, Eastern Band of Cherokee; Kent Lebsock, Lakota; Fidel Moreno, Yaqui/Huichol; Carlon Ami, Hopi/Tewa; Mary Defender?Wilson, Dakota/Hidatsa; Jan Stevens, Sac \& Fox; Walt Bresette, Red Cliff Ojibwe; Earl Tulley, Dine'; Floyd Buckskin, Pitt River; Andrew Becenti, Dine'; Barbara Bernacik, Laguna Pueblo; M.C. Balwin, Dine'; Joseph Campbell, Dakota; Elena Bautista Sparrow, Yujpik; Joseph Chasing Horse, Lakota; Charlotte Caldwell, Menominee; Tami Soreson, Ojibwe; Marylou Stillday, Ojibwe; Sarah James, Neestaii Gwichin Athapascan; Tom Goldtooth, Dine'/Dakota; Michael Sturdevant, Menominee; 
Jose Barrero, Taino; James Main, Sr, Gros Ventre; Roy Taylor,

Pawnee/Choctow; Barbara McCloud, Puyallup; Janet McCloud, Tulalip;

Valerie Taliman, Dine'; Wilbur Slockish Jr, Yakama Klickitat Band; Dana

Mitchell, Penobscot; James Ransom, Haudenesaunee; Robert Shimek, Ojibwe;

Jimbo Simmons, Choctow; Patrick Spears, Lakota; Carlos Pelayo, Yoreme;

Dean Suagee, Oklahoma Band of Cherokee; Angel Valencia, Yaqui; Mose

Walkingstick, Eastern Band of Cherokee; Geraldine Warledo,

Cheyenne/Arapaho; Jackie Warledo, Seminole. 
Anexo VIII - Declaração de Anchorage

The Anchorage Declaration

24 April 2009

From 20-24 April, 2009, Indigenous representatives from the Arctic, North America, Asia, Pacific, Latin America, Africa, Caribbean and Russia met in Anchorage, Alaska for the Indigenous Peoples' Global Summit on Climate Change. We thank the Ahtna and the Dena'ina Athabascan Peoples in whose lands we gathered.

We express our solidarity as Indigenous Peoples living in areas that are the most vulnerable to the impacts and root causes of climate change. We reaffirm the unbreakable and sacred connection between land, air, water, oceans, forests, sea ice, plants, animals and our human communities as the material and spiritual basis for our existence.

We are deeply alarmed by the accelerating climate devastation brought about by unsustainable development. We are experiencing profound and disproportionate adverse impacts on our cultures, human and environmental health, human rights, well-being, traditional livelihoods, food systems and food sovereignty, local infrastructure, economic viability, and our very survival as Indigenous Peoples.

Mother Earth is no longer in a period of climate change, but in climate crisis. We therefore insist on an immediate end to the destruction and desecration of the elements of life.

Through our knowledge, spirituality, sciences, practices, experiences and relationships with our traditional lands, territories, waters, air, forests, oceans, sea ice, other natural resources and all life, Indigenous Peoples have a vital role in defending and healing Mother Earth. The future of Indigenous Peoples lies in the wisdom of our elders, the restoration of the sacred position of women, the youth of today and in the generations of tomorrow.

We uphold that the inherent and fundamental human rights and status of Indigenous Peoples, affirmed in the United Nations Declaration on the Rights of Indigenous Peoples (UNDRIP), must be fully recognized and respected in all decision-making processes and activities related to climate change. This includes our rights to our lands, territories, environment and natural resources as contained in Articles 25-30 of the UNDRIP. When specific programs and projects affect our lands, territories, environment and natural resources, the right of Self Determination of Indigenous Peoples must be recognized and respected, emphasizing our right to Free, Prior and Informed Consent, including the right to say "no". The United Nations Framework Convention on Climate Change (UNFCCC) agreements and principles must reflect the spirit and the minimum standards contained in UNDRIP.

\section{Calls for Action}

1. In order to achieve the fundamental objective of the United Nations Framework Convention on Climate Change (UNFCCC), we call upon the fifteenth meeting of the 
Conference of the Parties to the UNFCCC to support a binding emissions reduction target for developed countries (Annex 1) of at least 45\% below 1990 levels by 2020 and at least $95 \%$ by 2050 . In recognizing the root causes of climate change, participants call upon States to work towards decreasing dependency on fossil fuels. We further call for a just transition to decentralized renewable energy economies, sources and systems owned and controlled by our local communities to achieve energy security and sovereignty.

In addition, the Summit participants agreed to present two options for action: some supported option A and some option B. These are as follows:

A. We call for the phase out of fossil fuel development and a moratorium on new fossil fuel developments on or near Indigenous lands and territories.

B. We call for a process that works towards the eventual phase out of fossil fuels, without infringing on the right to development of Indigenous nations.

2. We call upon the Parties to the UNFCCC to recognize the importance of our Traditional Knowledge and practices shared by Indigenous Peoples in developing strategies to address climate change. To address climate change we also call on the UNFCCC to recognize the historical and ecological debt of the Annex 1 countries in contributing to greenhouse gas emissions. We call on these countries to pay this historical debt.

3. We call on the Intergovernmental Panel on Climate Change (IPCC), the Millennium Ecosystem Assessment, and other relevant institutions to support Indigenous Peoples in carrying out Indigenous Peoples' climate change assessments.

4. We call upon the UNFCCC's decision-making bodies to establish formal structures and mechanisms for and with the full and effective participation of Indigenous Peoples.

Specifically we recommend that the UNFCCC:

a. Organize regular Technical Briefings by Indigenous Peoples on Traditional Knowledge and climate change;

b. Recognize and engage the International Indigenous Peoples' Forum on Climate Change and its regional focal points in an advisory role;

c. Immediately establish an Indigenous focal point in the secretariat of the UNFCCC;

d. Appoint Indigenous Peoples' representatives in UNFCCC funding mechanisms in consultation with Indigenous Peoples;

e. Take the necessary measures to ensure the full and effective participation of Indigenous and local communities in formulating, implementing, and monitoring activities, mitigation, and adaptation relating to impacts of climate change.

5. All initiatives under Reducing Emissions from Deforestation and Degradation (REDD) must secure the recognition and implementation of the human rights of Indigenous Peoples, including security of land tenure, ownership, recognition of land title according to traditional ways, uses and customary laws and the multiple benefits of forests for climate, ecosystems, and Peoples before taking any action.

6. We challenge States to abandon false solutions to climate change that negatively impact Indigenous Peoples' rights, lands, air, oceans, forests, territories and waters. 
These include nuclear energy, large-scale dams, geo-engineering techniques, "clean coal", agro-fuels, plantations, and market based mechanisms such as carbon trading, the Clean Development Mechanism, and forest offsets. The human rights of Indigenous Peoples to protect our forests and forest livelihoods must be recognized, respected and ensured.

7. We call for adequate and direct funding in developed and developing States and for a fund to be created to enable Indigenous Peoples' full and effective participation in all climate processes, including adaptation, mitigation, monitoring and transfer of appropriate technologies in order to foster our empowerment, capacity-building, and education. We strongly urge relevant United Nations bodies to facilitate and fund the participation, education, and capacity building of Indigenous youth and women to ensure engagement in all international and national processes related to climate change.

8. We call on financial institutions to provide risk insurance for Indigenous Peoples to allow them to recover from extreme weather events.

9. We call upon all United Nations agencies to address climate change impacts in their strategies and action plans, in particular their impacts on Indigenous Peoples, including the World Health Organization (WHO), United Nations Educational, Scientific and Cultural Organization (UNESCO) and United Nations Permanent Forum on Indigenous Issues (UNPFII). In particular, we call upon all the United Nations Food and Agriculture Organization (FAO) and other relevant United Nations bodies to establish an Indigenous Peoples' working group to address the impacts of climate change on food security and food sovereignty for Indigenous Peoples.

10. We call on United Nations Environment Programme (UNEP) to conduct a fast track assessment of short-term drivers of climate change, specifically black carbon, with a view to initiating negotiation of an international agreement to reduce emission of black carbon.

11. We call on States to recognize, respect and implement the fundamental human rights of Indigenous Peoples, including the collective rights to traditional ownership, use, access, occupancy and title to traditional lands, air, forests, waters, oceans, sea ice and sacred sites as well as to ensure that the rights affirmed in Treaties are upheld and recognized in land use planning and climate change mitigation strategies. In particular, States must ensure that Indigenous Peoples have the right to mobility and are not forcibly removed or settled away from their traditional lands and territories, and that the rights of Peoples in voluntary isolation are upheld. In the case of climate change migrants, appropriate programs and measures must address their rights, status, conditions, and vulnerabilities.

12. We call upon states to return and restore lands, territories, waters, forests, oceans, sea ice and sacred sites that have been taken from Indigenous Peoples, limiting our access to our traditional ways of living, thereby causing us to misuse and expose our lands to activities and conditions that contribute to climate change.

13. In order to provide the resources necessary for our collective survival in response to the climate crisis, we declare our communities, waters, air, forests, oceans, sea ice, traditional lands and territories to be "Food Sovereignty Areas," defined and directed by 
Indigenous Peoples according to customary laws, free from extractive industries, deforestation and chemical-based industrial food production systems (i.e. contaminants, agro-fuels, genetically modified organisms).

14. We encourage our communities to exchange information while ensuring the protection and recognition of and respect for the intellectual property rights of Indigenous Peoples at the local, national and international levels pertaining to our Traditional Knowledge, innovations, and practices. These include knowledge and use of land, water and sea ice, traditional agriculture, forest management, ancestral seeds, pastoralism, food plants, animals and medicines and are essential in developing climate change adaptation and mitigation strategies, restoring our food sovereignty and food independence, and strengthening our Indigenous families and nations.

We offer to share with humanity our Traditional Knowledge, innovations, and practices relevant to climate change, provided our fundamental rights as intergenerational guardians of this knowledge are fully recognized and respected. We reiterate the urgent need for collective action.

Agreed by consensus of the participants in the Indigenous Peoples' Global Summit on Climate Change, Anchorage Alaska, April 24th 2009 
Anexo IX - Submissão da COICA à COP20 - "REDD+ más allá del carbono"

\section{Coordinadora de las Organizaciones Indígenas de la Cuenca Amazónica}

AIDESEP-APA-CIDOB-COIAB- CONFENAIE-FOAG- OIS- OPIAC-ORPIA

\section{Redd+ más allá del carbono y del mercado: Integralidad del Redd+ Indígena Amazónico}

El presente documento es el aporte de los pueblos indígenas amazónicos articulados en COICA en el debate de la CMNUCC de "REDD+ y beneficios más allá del carbono y de financiamientos más allá del mercado" que se procesa hacia la COP20 y COP21. COICA es una amplia articulación de 390 pueblos indígena, basadas en más de 5000 comunidades, que ocupan 170 mills de has, tituladas y demarcadas; y en un segundo nivel se agrupan en más de 200 organizaciones o federaciones locales; y éstas a su vez se estructuran en 09 organizaciones nacionales amazónicas de Brasil (COIAB), Perú (AIDESEP), Colombia (OPIAC), Ecuador (GOGONAE), Bolivia (CIDOB), Venezuela (ORPIA), Guyana (APA), Surinam (OIS) y Guyana Francesa (FOAG); las cuales se unifican en un cuarto nivel de articulación, como es COICA para la incidencia internacional.

1. Unicidad de los bosques tropicales amazónicos. Sustentar toda estrategia en el reconocimiento de la multiplicidad inter conectada de las 24 (o más) funciones o servicios eco sistémicos de las selvas tropicales. Implican funciones de abastecimiento: Alimentos, fibras y combustibles, recursos genéticos, sustancias bioquímicas, agua dulce. Funciones de regulación: resistencia a invasiones, polinización, dispersión de semillas, regulación de plagas, regulación de enfermedades, protección ante riesgos naturales, control de la erosión, purificación del agua). Funciones culturales: valores espirituales y religiosos, sistemas de conocimientos, educación e inspiración, recreación y valor estético o belleza. Funciones de sustento: producción primaria, provisión de hábitats, circulación de nutrientes, formación y retención de suelos, circulación del agua. Cabe resaltar, que dentro de esta diversidad funciones, están las de carácter climático, de las cuales se ha absolutizado la de mantener el balance de carbono, pero que deben incluir también otras funciones climáticas, como las de evapotranspiración, absorción y reflexión solar, almacenamiento de agua, protección contra la erosión producción de oxígeno atmosférico y efectos climáticos de larga distancia. No solo se trata de mega diversidad de funciones, sino sobre todo de su Unicidad, interrelación, interconexión e integralidad de funciones. Por ello, para los amazónicos, el concepto de "Bosques" es limitado, porque se centra, aisla y absolutiza en los árboles. Al contrario, el concepto de las "selvas" reflejan la unidad entre mega diversidad biológica y cultural

2. Megadiversidad cultural y biológica. Ambas se presentan, se construyen, se mantienen em forma unida e interrelacionada. No hay una sin la otra. La mega diversidad biológica está unida a la mega diversidad cultural de los pueblos indígenas, porque son ellos quienes la construyeron ancestralmente y la siguen construyendo. La naturaleza, no como entidad "pura" sino cultural y socialmente construida. Interdependencia entre pueblos indígenas y ecosistemas y bosques amazónicos, que implica la necesidad de enfoques holísticos sobre la amazonía y evitar enfoques 
reduccionistas o absolutistas a uno de sus elementos, por encima de los otros, así sea éste el referido a la absorción de carbono por ejemplo.

3. El balance de carbono, como capacidad de absorción y almacenaje de carbono, es una función ecosistémica importante, pero inseparable de las demás. La reserva de carbono es indesligable de las capacidades de dispersión de semillas, ambos conectados a formación de suelos, y todos ellos al manejo cultural indígena de la totalidad de las selvas. Implica que no hay absorción de carbono sin cobeneficios, o los demás beneficios múltiples. Y a la inversa también, dichos co-beneficios van siempre acompañados de reservas de carbono. Cabe precisar, además, que diversos estudios han demostrado que los territorios indígenas tienen tasas de deforestación menores que las áreas naturales protegidas. A pesar que las segundas han recibido y reciben todavía la mayor atención de los Estados y de la cooperación internacional. Implica que el factor cultural, el de las prácticas sociales de convivência armónica con el bosque, resultan a la larga, más decisivas que los factores de financiamiento, y por tanto del propio mercado.

4. La Conservación integral incluye al carbono, pero la conservación aislada del carbono no necesariamente incluye a las demás funciones ecosistémicas. Asumir que si los bosques están enteros, el carbono también lo está obviamente. Si los impulsores de emisiones actúan sobre la integralidad del bioma, la mitigación eficaz es actuando integralmente en lugar de aislar las acciones sobre la función de absorción de carbono. Para que los pueblos indígenas controlen y mantengan las reservas del carbono almacenadas, requieren controlar la integralidad del ecosistema, incluyendo suelo, subsuelo, vuelo forestal, aguas, recursos biogenéticos. Tomar muy en cuenta, que el carbono puede estar "entero o conservado", pero no necesariamente el resto de la selva/bosque. Un ejemplo de ello pueden ser las "reservas de carbono" en plantaciones, bio-combustibles, "desiertos verdes".

5. Re-evaluación y distinciones entre macro y micro mediciones en el MRV. Como lo sustenta el "Informe Munden" es importante considerar las opciones de macro-medición en base a metodologias conocidas y simplificadas, como las imágenes satelitales, inventario forestal y evaluación de parcelas demostrativas. También dicho Informe, sustenta que la micro-medición en base a mediciones detallistas del carbono en el tronco, hojas, frutos, raíces, suelo, sub suelo y hojarasca; es muy controversial. Compitiendo entre metodologías y las entidades que las sustentan, que volverán impracticable o poco viable, una homogenización universal de micro-MRV, y más difícil aún, tener sistemas de seguros internacionales para transacciones en base a micro-MRV en sí mismo controversiales. Frente a ello, para verificar la integralidad, pervivencia, dinamismo del bosque, es suficiente con la macro-medición del MRV, y que también incluye una aproximación aproximada y gruesa del balance de carbono, pero suficiente para las necesidades de mitigar el cambio climático. La eficacia, eficiencia y sostenibilidad de la mitigación y adaptación como respuestas frente a la crisis climática requieren solo de macro-medición MRV

6. Carbono y mercado. No es posible prever dinámicas de comercio o mercado privado, de créditos de carbono, sin el componente de lucro creciente, menos aún si se trata de commodities intangibles y a futuro como el de créditos de carbono. No es el objetivo de mitigar la crisis climática, en sí mismo, sino el mercado y su lucro, el que requiere de ese nivel de micro-mediciones que sean exigibles en los contratos de "pagos por resultados". No debe eludirse y más bien analizar las consecuencias de las inevitables 
exigencias del comercio lucrativo en el mercado de commodities de créditos de carbono. Más grave aún, considerando la emergencia e impunidad de casos de la llamada "piratería de carbono" en donde el lucro lleva al extremo de la estafa a comunidades indígenas. El reduccionismo al carbono, se acompaña del reduccionismo del mercado privatista. Por otra parte "el carbono forestal", no puede ni debe ser considerado "igual" que el carbono de fuentes industriales. Es evidente que el carbono forestal, es de una dimensión superior, por las múltiples funciones ecosistémicas a las que está inter conectado y que son adicionales y contributivas a las de mitigación climática. Un escenario de reduccionismo al carbono, va a llevar a separar mitigación (comercio de créditos de carbono) de la adaptación (sin comercio o mercado a la vista) a pesar de que en la realidad ambos procesos coinciden en los mismos territorios amazónicos y en las mismas dimensiones temporales. La COP19 aportó un cambio de enfoque al integrar mitigación y adaptación, que debe ser profundizado; y en el caso de la adaptación, debe posibilitar un empoderamiento mayor de las mujeres indígenas que afrontan diaria y vitalmente los dramáticos impactos en la horticultura de la fractura en los ciclos climáticos.

7. Selva/carbono y mecanismos públicos/mercado. Los fondos públicos asignados e implementados en el marco de la CMNUCC, como el actual Fondo de Inversión Climática (FIC) y el GCF (Green Climate Fund), abarcarán mayores acciones de adaptación y en mayor medida que los de mitigación. Es importante la tendencia y propuestas a unificar e interrelacionar el financiamiento para ambos procesos (mitigación y adaptación) bajo el GCF. Falta considerar y analizar las posibles contradicciones, en los niveles nacionales, entre procesos de privatización de bienes y servicios forestales, y el control público de los derechos sobre el carbono y otros "servicios ecosistémicos". Los países amazónicos aplicarán a ambos financiamientos de mitigación y adaptación, y es inevitable la interrelación de sus políticas y proyectos sobre ambas dimensiones, porque ocurren sobre el mismo bioma y ecosistemas mazónicos. Los mecanismos públicos de financiamiento, a nivel nacional, como lo enseñan ejemplos como los de Acre (Brasil), pueden incluir aportes del sector privado bajo diversas modalidades para compensar su huella ecológica. Los mecanismos financieros del mercado privado de carbono, no suelen incluir fondos públicos y por la lógica exagerada de "libre competencia", pueden llevar a reducir al mínimo las regulaciones públicas, con los peligros de aumento de conflictos con derechos indígenas y ambientales.

\section{Considerar las dificultades y controversias del mercado de créditos de carbono:}

Para homogeneizar estandarizar las metodologías de las micro mediciones de carbono, como requisito para intercambiar créditos de carbono semejantes. Para establecer garantías o seguros en las transacciones de commodities intangibles y a futuro. Para establecer mecanismos eficaces de acreditación, monitoreo, regulación, veeduría, sanciones de actores privados en el comercio de carbono. El desprestigio del libre mercado desregulado de commodities de créditos de carbono por el aumento y la impunidad de la piratería de carbono. La controversia de facilitar la continuidad de emisiones industriales (en el norte o en el sur) y la falsa "compensación" con pagos por créditos de carbono. Los peligros del despliegue descontrolado y desregulado de libre mercado de los commodities de carbono y la expansión de expectativas de lucro financiero, que faciliten la especulación financiera y posibles "burbujas financieras" insostenibles. Generación de conflictos por la lenta definición de regulaciones globales 
nacionales, paralela al aumento de contratos especulativos y de mala fé en territorios indígenas.

9. Ventajas de financiamiento público sobre Redd+, con fondos privados y bajo control social. Los mecanismos financieros públicos sobre Redd+, a nivel nacional e internacional, probablemente avanzan más y mejor que los mecanismos privados. El GEF, FIC, FIP y ahora GCF funcionan y se expanden, frente al estancamiento y menor precio del mercado offset, y ello en medio de la crisis económica en los países de las posibles empresas inversoras. La crisis climática se agrava indefectiblemente y los mpuestos a la huella ecológica son inevitables, siendo previsible el aumento de los fondos públicos para fines ambientales. Es indudable que el sector privado tiene un rol importante para reducir y compensar su huella ecológica, pero de ahí no se deduce que deba tener un rol directriz frente a los procesos de mitigación de la crisis climática, como el Redd+. Su rol sigue siendo importante como reconversor a tecnologías de bajo carbono y tributando según su huella ecológica. Los responsables de la crisis climática deben pagar la deuda ecológica y no aspirar a lucrar con ella imponiendo un mercado de commodities de créditos de carbono. Adicionalmente, siguen las dificultades para homogenizar o estandarizar las metodologías de las micro mediciones de carbono, como requisito para intercambiar créditos de carbono supuestamente semejantes (carbono industrial y carbono forestal). En esehorizonte, deben valorarse tendencias de innovación, como son la alianza del clima de 1300 ciudades europeas (Klimabundnis) que reducen importantes niveles de emisiones industriales, y apoyan la reducción de emisiones forestales, sin estar interesadas pasar por las controversias del Offset.

10. Condicionantes y determinantes de la resiliencia de los ecosistemas y pueblos indígenas Amazónicos. Los pueblos indígenas están entre las poblaciones más vulnerables y más impactados ante la crisis climática. Siguen crecientes las amenazas globales y locales de la crisis climática ante el bioma amazónico y sus ecosistemas. Frente a ello, el objetivo de reducir la vulnerabilidad de pueblos y ecosistemas amazónicos requiere un enfoque integral, holístico y que articule mitigación y adaptación simultáneamente, tal como fuera adoptado en la COP19. Hay la necesidad de abordaje integral de los impulsores de emisiones derivados del consumismo, extractivismo y desarrollismo. El peligro de refugiados climáticos en las poblaciones amazónicas, impulsa el manejo de grandes bloques forestales para una mayor resiliencia de las poblaciones indígenas

11. La propuesta de Redd+ Indígena Amazónico (RIA) recupera y garantiza el enfoque holístico más allá del carbono. El manejo holístico de Territorios de Vida Plena, como sinónimo de RIA, basado em sociedades y culturas, indígenas, organizadas holísticamente, integrando en todas sus dimensiones naturaleza, sociedad, cultura y espiritualidad. Basada en el enfoque de "beneficios múltiples" o "cobeneficios" que incluyen al carbono, para conservarlo y mejorar la capacidad de absorción. Evita el reduccionismo de aislar el carbono de las demás funciones ecosistémicas. Ese enfoque es respaldado por la resolución de la UICN del 2012, de considerar a los territorios indígenas, en sí mismos, como "espacios de conservación” sustentable, más eficaces y eficientes y sostenibles que las áreas naturales protegidas. Se refuerza además por el derecho (Convenio 169-OIT y la DNUDPI) a controlar el "tipo de desarrollo" indígena, mediante Planes de Vida de los Pueblos Indígenas y con salvaguardas que promuevan dichos planes y cambiando los paradigmas extractivistas y desarrollistas convencionales. 
12. La propuesta del RIA garantiza mitigación, adaptación y las conexiones entre ambos. Los impulsores (drivers) de la deforestación y degradación nacional y global, afectan la pervivencia de los Pueblos indígenas. Nuestros pueblos, resistieron, resisten y resistirán dichos drivers, cualquiera fuera el escenario futuro del Redd+. Los pueblos indígenas, somos culturas dinámicas en permanente "adaptación tradicional" a los ecosistemas amazónicos, y nuestros conocimientos son sustanciales para la "adaptación moderna" como parte de un diálogo de saberes, con la modernidad, en un marco de horizontalidad e innovación. Los Pueblos Indígenas garantizan la pertinencia, eficacia, eficiencia y sostenibilidad de la mitigación y adaptación climáticas, al ser sociedades y culturas, organizadas holísticamente, integrando en todas sus dimensiones naturaleza, sociedad, cultura y espiritualidade

13. La propuesta de RIA va más allá del mercado, aunque lo incluye, pero lo redefine y establece bajo control social. Implica la capacidad de negociación global de los territorios indígenas, que abarcan 210 millones de has con impactos en el $27 \%$ del bioma amazónico y el $13 \%$ de los bosques tropicales del planeta. RIA ofrece reducir emisiones en más de 5 millones has. con experiencias pilotos en 5 países, para extenderlos a la amplitud y diversidad de territorios indígenas en el bioma amazónico, son atributos adicionales, de requerir menor inversión, reducción de la conflictividad y complejidad, y mayor rapidez de resultados. RIA propone financiamiento público de Planes de Vida de los Pueblos Indígenas que incluyen macro-mediciones de absorción de carbono, pero no la venta o comercialización como commodities de créditos de carbono. RIA propone financiamiento público, internacional, nacional o subnacional, bajo regulaciones estatales, control social, y aportes privados como compensación por su huella ecológica. 